NBER WORKING PAPER SERIES

\title{
THE VALUE OF CONNECTIONS IN TURBULENT TIMES: EVIDENCE FROM THE UNITED STATES
}

\author{
Daron Acemoglu \\ Simon Johnson \\ Amir Kermani \\ James Kwak \\ Todd Mitton \\ Working Paper 19701 \\ http://www.nber.org/papers/w19701 \\ NATIONAL BUREAU OF ECONOMIC RESEARCH \\ 1050 Massachusetts Avenue \\ Cambridge, MA 02138 \\ December 2013
}

We thank Isil Erel, Taylor Nadauld, and René Stulz for sharing data. For helpful comments we thank Josh Angrist, Caroline Hoxby, Suresh Naidu, Francesco Trebbi, and people who provided comments during or after our talks at MIT, Northwestern, Harvard Business School, the International Monetary Fund, the University of Alberta, BYU, Yale, the University of California at Berkeley, and the 2012 Econometric Society meetings. We are also grateful for constructive suggestions from some former officials. The views expressed herein are those of the authors and do not necessarily reflect the views of the National Bureau of Economic Research.

At least one co-author has disclosed a financial relationship of potential relevance for this research. Further information is available online at http://www.nber.org/papers/w19701.ack

NBER working papers are circulated for discussion and comment purposes. They have not been peerreviewed or been subject to the review by the NBER Board of Directors that accompanies official NBER publications.

(C) 2013 by Daron Acemoglu, Simon Johnson, Amir Kermani, James Kwak, and Todd Mitton. All rights reserved. Short sections of text, not to exceed two paragraphs, may be quoted without explicit permission provided that full credit, including (C) notice, is given to the source. 
The Value of Connections in Turbulent Times: Evidence from the United States

Daron Acemoglu, Simon Johnson, Amir Kermani, James Kwak, and Todd Mitton

NBER Working Paper No. 19701

December 2013

JEL No. G01,G14,G21,G28

\section{ABSTRACT}

The announcement of Timothy Geithner as nominee for Treasury Secretary in November 2008 produced a cumulative abnormal return for financial firms with which he had a connection. This return was about $6 \%$ after the first full day of trading and about $12 \%$ after ten trading days. There were subsequently abnormal negative returns for connected firms when news broke that Geithner's confirmation might be derailed by tax issues. Excess returns for connected firms may reflect the perceived impact of relying on the advice of a small network of financial sector executives during a time of acute crisis and heightened policy discretion.

Daron Acemoglu

Department of Economics, E18-269D

MIT

77 Massachusetts Avenue

Cambridge, MA 02139

and CIFAR

and also NBER

daron@mit.edu

Simon Johnson

MIT Sloan School of Management

100 Main Street, E52-562

Cambridge, MA 02142

and NBER

sjohnson@mit.edu

Amir Kermani

Haas School of Business and

Department of Economics

University of California, Berkeley

2220 Piedmont Ave

Berkeley CA 94720

amir@haas.berkeley.edu
James Kwak

University of Connecticut

School of Law

james.kwak@law.uconn.edu

Todd Mitton

Marriott School

Brigham Young University

684 TNRB

Provo, UT 84602

todd.mitton@byu.edu 


\section{Introduction}

On Friday, November 21, 2008, the news leaked that Timothy Geithner - then president of the Federal Reserve Bank of New York - would be nominated by President-elect Barack Obama to become Secretary of the Treasury of the United States. Over the next ten trading days, financial firms with a connection to Geithner experienced a cumulative abnormal return of about $12 \%$ (relative to other financial sector firms). When Geithner's nomination ran into trouble in January 2009, due to unexpected tax issues, there was a fall in the value of Geithnerconnected firms - although this effect is smaller and less precisely estimated than the increases that were observed in November. How should we interpret these results?

This pattern seems unlikely to be a fluke of the data or a result of mismeasurement. We use three different ways of identifying connections between financial institutions' executives and Geithner: (i) executives who had meetings with Geithner during 2007-08; (ii) executives who belonged to the same nonprofit boards and groups as Geithner; and (iii) executives of firms located in New York City, who would be close in proximity to the New York Fed. Our results are essentially the same across all three measures of connections (although somewhat weaker for the New York City measure), and they are robust across a wide range of checks, including with various size controls and when we drop outliers.

Our results are also unlikely to reflect higher than normal returns for firms most affected by the crisis and thus more likely to benefit from the appointment of a competent Treasury Secretary. The results remain robust when we compare connected firms to non-connected firms with similar size, profitability, leverage and prior stock price behavior, or when we control for: how intensely firms were affected in the most severe phase of the crisis during SeptemberOctober 2008; how their stock price rose when capital was injected into big banks in October 2008; or how much they were exposed to troubled assets (in particular, residential mortgagebacked securities). Episodes of purely supportive policy - such as the Bear Stearns rescue, the AIG bailout, or the passage of the Emergency Economic Stabilization Act - did not cause the same robust pattern of abnormal returns for Geithner-connected firms. We also examine

evidence on the market-perceived probability of bankruptcy from credit default swap spreads, although the available sample for these data is smaller than for equities. We find the same pattern in CDS spread data as in equity data - i.e., there was a perceived benefit to creditors (in the form of lower implied default risk) when the firms' executives were connected to Geithner.

There are at least three reasons why market participants may have expected benefits for 
Geithner-connected firms. First, they may have expected that some form of explicit corruption could take place. In countries with weak institutions and much policy discretion in the hands of politicians, such as Indonesia, Malaysia, or Pakistan, potential corruption is a reasonable interpretation of stock price movements for politically connected firms. ${ }^{1}$ But corruption is not plausible as an explanation for what happened in the United States. Econometric results that show large effects for political connections are typically based on data from countries with weak institutions. In contrast, by most measures and at most times, the United States has fairly strong institutions. Moreover, Geithner is widely regarded as an honest public servant who is very unlikely to have acted on the basis of personal financial gain. Studies of policymaking under the Obama administration by Suskind (2011) and Scheiber (2011) and firsthand accounts by Bair (2012) and Barofsky (2012) - none of which are particularly sympathetic to Geithner - contain absolutely no suggestion of corruption. Geithner has also never run for public office and seems unlikely to ever do so, making political contributions irrelevant. ${ }^{2}$

Second, market participants may have believed that Geithner's policy preferences were generally consistent with the interests of the financial institutions with which he was connected. This might have represented a type of "cultural capture" of key official decision-makers and thinkers by Wall Street (Bhagwati (1998), Johnson and Kwak (2011)). According to this theory, instead of favoring firms because he had connections with them, Geithner's prior connections had already shaped his perspectives on the financial sector and on the crisis that was still unfolding. In particular, his close connections to large, complex, Wall Street banks might have persuaded him that broader economic prosperity required rescuing those banks on relatively generous terms (for shareholders, as well as executives and creditors). Our results, however, are not based on a comparison of financial to non-financial firms or of large relative to small financial firms. ${ }^{3}$ Rather, as already noted, they are driven by a comparison of connected to non-connected firms of similar size. Even if Geithner took the worldview that Wall Street

\footnotetext{
${ }^{1}$ For example, in a seminal study, Fisman (2001) found that being connected to President Suharto accounted for 23 percent of firms' value on average in Indonesia in the mid-1990s (where the events were rumors about the president's health). For Malaysia in the late 1990s, Johnson and Mitton (2003) found that connections to Prime Minister Mahathir accounted for around 20 percent of firms' total stock market value in a crisis, where the event was the fall from power of Anwar Ibrahim, the Minister of Finance. Similar results are found in Pakistan by Khwaja and Mian (2005), in a cross-country setting by Dinç (2005), and in Weimar Germany by Ferguson and Voth (2008).

${ }^{2}$ Duchin and Sosyura (2012) find that politically connected firms were more likely to receive TARP funds, and also that such firms performed worse than non-connected firms. However, they measure connections to Congress, not to Secretary Geithner.

${ }^{3}$ Similarly, we show below that our results are not driven by Citigroup or other financial firms that are considered by policymakers or markets as "too big to fail". In all cases, we find that investors considered there to be value in being personally connected to Geithner, quite aside from any "too big to fail" issues.
} 
banks were "too big to fail", this cannot directly account for our results.

Third, the market may have subscribed to a "social connections meets the crisis" hypothesis: that connections would matter during a time of crisis and increased policy discretion. It was perhaps reasonable to suppose that immediate action with limited oversight would have to be taken, and that officials would rely on a small network of established confidantes for advice and assistance. Powerful government officials are no different from the rest of us; they know and trust a limited number of people. It is therefore natural to tap private sector friends, associates, and acquaintances with relevant expertise when needed - including asking them for advice and hiring them into government positions. Even with the best intentions, beliefs are presumably shaped by self-interest, particularly when the people involved were, are, or will be executives with fiduciary responsibility to shareholders. These tendencies can be checked during ordinary times by institutional constraints and oversight, but during times of crisis and urgency, social connections are likely to have more impact on policy. ${ }^{4}$

Our findings show a stronger effect for connections than is standard in most related research on the United States. ${ }^{5}$ In part, previous studies have examined different kinds of connections, focusing on the legislature, where the impact of a single individual is likely to be limited. For example, the so-called Jeffords Effect - named after a Senator who switched parties unexpectedly, causing a change of control in the U.S. Senate - was found to be worth around $1 \%$ of firm value (Jayachandran (2006)). Roberts (1990) found statistically significant but small effects on connected firms from the unexpected death of a U.S. Senator. Fisman et al. (2012) studied the value of connections to former Vice President Dick Cheney, driven by events such as his heart attacks, surprise news about his political career, the original Bush-Cheney "hanging chad"

\footnotetext{
${ }^{4}$ Particularly important may have been Geithner's connections through his long-term relationship with Robert Rubin, who was Treasury Secretary in the Clinton administration, a former co-chair of Goldman Sachs, and more recently a leading board member at Citigroup (he resigned from the latter position in January 2009). From November 2003, Geithner was president of the Federal Reserve Bank of New York - an institution that has traditionally served as the eyes and ears of the Federal Reserve on Wall Street, but which is sometimes considered to have become too much influenced by the thinking at large financial institutions. Formal responsibility for supervision rests with the Board of Governors in Washington D.C., but the New York Fed is very much engaged in collecting information and interpreting what is going on. By tradition, the president of the New York Fed plays a particularly important role in managing relationships between government officials and financial services executives who are based in New York ("Wall Street", broadly defined). He is also, by convention, vice chair of the Federal Open Market Committee, which sets monetary policy. (All presidents of the New York Fed to date have been men.)

${ }^{5}$ Akey (2013) presents findings that are similar in magnitude to ours, but for congressional elections where "the wedge between firms connected to a winning politician and firms connected to a losing politician is $1.7 \%$ to $6.8 \%$ of firm equity value." Goldman, Rocholl, and So (2009) find that when George W. Bush won the presidency in 2000 (and Republicans controlled the Senate and the House of Representatives), Republicanlinked firms gained 3\%-5\% relative to Democrat-linked firms, but the links they measure are not exclusive to the executive branch.
} 
presidential election victory in 2000, and Iraq war developments, and found no evidence of significant effects. They concluded: "Contrary to conventional wisdom, we find that in all cases the value of ties to Cheney is precisely estimated as zero. We interpret this as evidence that U.S. institutions are effective in controlling rent-seeking through personal ties with high-level government officials". ${ }^{6}$

But Geithner ascended to the highest level of power at an unusual moment, with many ideas in flux and great differences of opinion between otherwise well-informed and experienced people. $^{7}$ During the intense crisis of 2008 there was a wide range of opinions among policy experts - and among potential Treasury Secretaries - regarding what should be done, with significant potential implications for shareholders and creditors of financial institutions.

During such an episode where immediate action is necessary, it is plausible that the usual institutional checks may not work and social connections may become more important as sources of both ideas and manpower. ${ }^{8}$ This interpretation is also consistent with recent work by Querubín and Snyder (2013). Using a regression discontinuity approach, they find that American politicians were not able to enrich themselves before or after the U.S. Civil War, but during the war there were substantial opportunities for personal gain - either because there was more government spending or because news media were distracted or both.

Section 2 reviews the historical context and why market participants may have expected connected firms to potentially perform better. Section 3 explains our coding of connections and discusses the other variables we use. Section 4 presents our basic results and a range of robustness checks. Section 5 analyzes the effects of Geithner's tax issues, which temporarily jeopardized his nomination in January 2009. Section 6 discusses the design and implementation of bailout policy and financial reform under the Geithner Treasury. Section 7 concludes. The Online Appendix (Tables A1 through A10) contains additional results and details on the data.

\footnotetext{
${ }^{6}$ Lower down the official hierarchy, there is certainly more rent-seeking behavior. For example, Dube, Kaplan and Naidu (2011) find that (leaked) credible private information on coup attempts backed by the United States does move stock prices.

${ }^{7}$ There has always been lobbying in the United States, but other evidence suggests this may have been more intense during the recent boom and bust, as the stakes became very high. Igan, Mishra, and Tressel (2011) find that lobbying of legislators by lenders was associated with more risk-taking before the crisis and worse outcomes in 2008, while Igan and Mishra (2012) examine how the political influence of the financial sector affected deregulation. Mian, Sufi, and Trebbi (2010) establish that members of Congress were more likely to support the Emergency Economic Stabilization Act of 2008 when they received higher contributions from the financial services industry. Tahoun (2013) finds that members of Congress own stock in firms that contribute to their campaigns, and that such firms receive more in government contracts.

${ }^{8}$ Faccio (2006) finds connections of various kinds exist everywhere. Faccio, Masulis, and McConnell (2006) show connected firms are more likely to receive bailouts across a wide range of countries, but the probability of bailout is much lower in richer countries. See also Chiu and Joh (2004) and Dinç (2005).
} 


\section{The Context and Event}

\subsection{Historical Context}

The financial crisis first became clearly evident in mid-2007 when problems with subprime mortgages began causing major losses at some hedge funds and structured investment vehicles. The crisis grew in severity during the spring and summer of 2008 - culminating in the collapse of Lehman Brothers and a full-blown financial panic in mid-September.

These developments prompted Treasury Secretary Henry Paulson and Federal Reserve Chairman Ben Bernanke to propose what eventually became the Emergency Economic Stabilization Act (EESA), whose centerpiece was the $\$ 700$ billion Troubled Assets Relief Program (TARP). ${ }^{9}$ On October 14, 2008, using this legal authority, the Treasury Department, the Federal Reserve, and the Federal Deposit Insurance Corporation (FDIC) announced two measures that began to calm the markets. First, they revealed that $\$ 250$ billion of TARP money was available to recapitalize financial institutions and, of this amount, $\$ 125$ billion had already been accepted by nine major banks. Second, there would be a program under which the FDIC guaranteed new debt issued by banks. ${ }^{10}$ By mid-November, however, when President-elect Barack Obama was selecting his Treasury Secretary, the crisis was far from over.

\subsection{Channels of Influence}

Why might market participants have believed that the nomination of Timothy Geithner as Treasury Secretary would be good for Geithner-connected firms relative to non-connected firms? There are two potential channels of influence that do not appear to operate. The first possibility is some form of expected material compensation. One possibility could be outright corruption, in which firms or their lobbyists pay officials directly for favors. As we have already emphasized, there is no plausible evidence to suggest that the Geithner appointment could have implied corruption. Geithner is known to be honest and the United States has tough anti-bribery rules that remained effective even during the financial crisis.

\footnotetext{
${ }^{9}$ On September 18, 2008, Paulson and Bernanke provided a dramatic briefing to congressional leaders. According to Chris Dodd, then chair of the Senate Banking Committee, they were told "that we're literally maybe days away from a complete meltdown of our financial system, with all the implications here at home and globally." David Herszenhorn, "Congressional Leaders Stunned by Warnings," The New York Times, September 19, 2008. The initial Treasury proposal, published on September 20, was only three pages long and did not specify any independent oversight mechanisms. "Text of Draft Proposal for Bailout Plan," The New York Times, September 20, 2008. The initial legislative proposal was rejected by the House of Representatives on September 29. An amended version passed and was signed into law on October 3, 2008.

10 "Joint Statement by Treasury, Federal Reserve and FDIC," Treasury Department Press Release, October 14, 2008, available at www.federalreserve.gov/newsevents/press/monetary/20081014a.htm.
} 
Another potential form of compensation is campaign financing, which sometimes matters a great deal in the United States - particularly when elected officials have a sense of what might encourage individual and corporate contributions to their campaigns. Geithner was unelected and has never sought election, so such considerations are unlikely to be relevant in his appointment or later decisions.

Material compensation also motivates the so-called "revolving door" between the public and private sectors, in which government officials are friendly with firms they oversee and subsequently - or perhaps consequently - secure lucrative positions with those firms. Yet before his nomination to Treasury, Geithner already had ample opportunity to land highly lucrative jobs in the private sector. It seems implausible to suggest that he was motivated or that anyone would think he could be motivated - by potential employment opportunities.

Second, there may well have been some "cultural capture" at the Treasury and in the Obama administration, meaning the convergence of perspectives and interests that occurs through immersion in a certain social or institutional context (e.g., working at the New York Fed or being friends with high-profile financiers). Once in office, this shared mindset could lead officials to decisions that favor the entire financial sector or perhaps some particular firms, such as Wall Street banks. This is a plausible hypothesis in general, but the specific evidence we present below cannot be explained by such cultural capture - our results indicate abnormal returns for well-connected financial firms relative to other less well-connected firms with similar characteristics, including size, profitability, leverage, and prior stock market performance.

One channel of influence that market participants in November 2008 could reasonably have expected to apply relates to the role of social connections. Access to government officials can be hugely beneficial, as witnessed by the large U.S. lobbying industry. When powerful politicians make decisions, they may be influenced by the people they talk to - and the people with whom they talk will likely be the people they know (Bertrand, Bombardini, and Trebbi (2011), and Blanes-i-Vidal, Draca, and Fons-Rosen (2012)). In addition to the simplest form of direct access through social connections - i.e., the fact that any official is more likely to take a phone call from someone he knows than from a person he does not know - another form of indirect access is provided by hiring. Any new administration must fill a large number of important positions, and connections are an influential factor in hiring decisions.

By November 2008, Geithner knew the leaders of the New York financial community very well, and it could reasonably be expected that he would continue to take their calls and listen to them seriously as Treasury Secretary. He would also be expected to place people he knew 
and trusted into important positions. ${ }^{11}$ Even if Geithner were not to favor connected firms directly, they could still benefit through the influence of their alumni.

The "social connections meets the crisis" hypothesis implies that market participants might expect Secretary Geithner's appointment to favor financial institutions based on pre-existing professional and social connections. Such positions might become even more valuable when policy discretion is higher and very consequential decisions need to be made - such as during the financial crisis that was raging in November 2008.

\subsection{Policy Discretion in November 2008}

As of November 2008, Congress had already explicitly granted broad powers to Treasury to intervene in the financial sector, and Secretary Paulson had pressured nine major banks into accepting $\$ 125$ billion of new government capital. ${ }^{12}$ Although Paulson's Capital Purchase Program (CPP) distributed capital on relatively generous terms, access was tightly controlled by Treasury. In late October, for example, PNC acquired National City after National City learned that its CPP application might not be approved. ${ }^{13}$ At the time, there was little transparency about how applications were reviewed and what criteria were being used to determine which banks received capital. The Treasury Department determined who received the benefit of both cheap capital and a government seal of approval (Veronesi and Zingales $(2010)) .^{14}$

In addition, the Capital Purchase Program placed significant holdings of preferred stock in the hands of the Treasury Department, as well as warrants on common stock. Although the preferred stock was non-voting and Treasury committed not to vote its shares of common stock,

\footnotetext{
${ }^{11}$ We should emphasize that drawing on pre-existing relationships on Wall Street is well-established practice for a Treasury Secretary, and did not begin with Geithner. For example, Henry Paulson brought in more and more Goldman Sachs alumni as the crisis deepened, including Neel Kashkari, who was charged with running TARP. Because of his expertise, Kashkari was initially kept on by Geithner.

${ }^{12}$ Damian Paletta, Jon Hilsenrath, and Deborah Solomon, "At Moment of Truth, U.S. Forced Big Bankers to Blink," The Wall Street Journal, October 15, 2008.

${ }^{13}$ Dan Fitzpatrick, David Enrich, and Damian Paletta, "PNC Buys National City in Bank Shakeout," The Wall Street Journal, October 25, 2008.

${ }^{14}$ The investment terms were considerably more favorable than those available from the private sector, such as in Warren Buffett's investment in Goldman Sachs. According to Bloomberg, the government received warrants worth $\$ 13.8$ billion in connection with its 25 largest equity injections; under the terms Buffett got from Goldman, those warrants would have been worth $\$ 130.8$ billion. In addition, TARP received a lower interest rate $(5 \%)$ on its preferred stock investments than did Buffett (10\%). Mark Pittman, "Paulson Bank Bailout in 'Great Stress' Misses Terms Buffett Won," Bloomberg, January 10, 2009. The TARP Congressional Oversight Panel had similar findings. TARP Congressional Oversight Panel, "February Oversight Report: Valuing Treasury's Acquisitions," February 6, 2009, available at www.gpo.gov/fdsys/pkg/CPRT-111JPRT47178/pdf/CPRT111JPRT47178.pdf. Although there were justifications for this subsidy - in particular, Treasury wanted broad participation in order to avoid stigmatizing particular banks - it still constituted potential expected value that the government was willing and able to transfer to specific financial institutions.
} 
this still left open the prospect of increased government influence; participating institutions were also subject to executive compensation and corporate governance requirements. ${ }^{15}$ The mechanics of implementing TARP were run within Treasury, giving significant discretion to the Treasury Secretary's appointees. ${ }^{16}$

\section{Data and Descriptive Statistics}

Our sample consists of all firms trading on the NYSE or NASDAQ that are categorized as banks or financial services firms in the Datastream database. Of these 678 firms, we exclude those that lack sufficient stock return data in the Datastream or TAQ databases to calculate abnormal returns for our Geithner announcement event. The remaining sample of 603 firms we refer to as the "full sample".

A potential complication is the Citigroup bailout which occurred between the news leak of Geithner's expected nomination on November 21 and the official announcement of his nomination on November 24, 2008. On Sunday, November 23, the U.S. government entered into a bailout agreement with Citigroup that provided Citigroup with a $\$ 20$ billion capital infusion through TARP, as well as guarantees on a pool of $\$ 306$ billion of troubled assets. ${ }^{17}$

Because the bailout occurred in the middle of the event window for the Geithner announcement, and because the bailout (or at least the size and timing of the bailout) was not entirely anticipated, it could complicate estimation of the effect of the Geithner announcement - at least to the extent that there is correlation between firms connected to Geithner and firms impacted by the Citigroup bailout news. ${ }^{18}$ In our tests, we address this issue in two ways. First, we report results for stock price reactions on November 21 only, which is prior to the Citigroup bailout announcement. While this approach avoids the confounding effects of the

\footnotetext{
15 "TARP Capital Purchase Program: Senior Preferred Stock and Warrants," available at online.wsj.com/public/resources/documents/PublicTermSheet1014.pdf.

${ }^{16}$ In addition to Neel Kashkari, Reuben Jeffrey, another Goldman alumnus, was named as interim chief investment officer, and several other ex-Goldman executives played important roles in the Paulson Treasury. Julie Creswell and Ben White, "The Guys from 'Government Sachs'," The New York Times, October 17, 2008; Deborah Solomon, "The Financial Crisis: Amid Turmoil, Tireless Team Of Advisers Backed Paulson," The Wall Street Journal, September 17, 2008.

17 "Joint Statement by Treasury, Federal Reserve, and the FDIC on Citigroup," November 23, 2008, available at www.federalreserve.gov/newsevents/press/bcreg/20081123a.htm

${ }^{18}$ It is not certain that a bailout would be positive news for Geithner-connected firms. We have tested the effect of Geithner connections on returns surrounding another significant government bailout, the bailout of Bank of America on January 16, 2009. The Bank of America bailout was similar in structure to the Citigroup bailout, and confirmed the government's willingness to take unprecedented measures to keep the largest banks afloat. However, our tests show that cumulative abnormal returns for Geithner-connected firms surrounding the Bank of America bailout are statistically insignificant, which suggests that Geithner-connected firms do not generally have positive responses to the news of significant government bailouts of major banks.
} 
Citigroup bailout, it is not entirely appealing because the post-leak return on November 21 is only one hour in length, and because some uncertainty about the nomination remained until the official announcement on November 24.

As a second approach, we exclude from our tests the firms that would be most likely to be affected by the bailout announcement. We rank all firms in the sample based on their return correlation with Citigroup during the period beginning the day of the Lehman collapse and ending the day before the Geithner nomination announcement. We drop firms that rank among the top $10 \%$ in correlation with Citigroup, and call this reduced sample our "base sample". ${ }^{19}$ To a large degree, the use of this base sample should eliminate the impact of the bailout announcement on our estimates.

Table 1 reports summary statistics of our variables for political connections and financial data. We identify connections to Geithner in three different ways. The first measure of connections, which we refer to as "schedule connections", identifies the number of times that Geithner interacted with executives from each firm while he was president of the New York Fed. We identify these interactions by searching Geithner's daily schedule for each day from January 2007 through January 2009. ${ }^{20}$ For example, a search of Geithner's schedule for Moody's Corporation reveals two interactions between Geithner and executives of Moody's. On July 5, 2007, the schedule reads, "11:30 a.m. to 12:00 p.m. Meeting w/Raymond McDaniel, Chairman \& CEO, Moody's Corporation", and on September 15, 2008, the schedule reads "11:00 a.m. to 12:00 p.m. Rating Agencies Meeting" and Raymond McDaniel is listed as one of the participants. Based on this information, we code Moody's schedule connections as two. Row 1 of Panel A of Table 1 reports descriptive statistics for this variable. By far the firm with the greatest number of interactions listed on Geithner's schedule is Citigroup, with a total of 34. Panel A of Appendix Table A1 lists all of the sample firms found on Geithner's schedule and the number of interactions. The average number of schedule connections, conditional on a firm having at least one connection, is 4.96 .

The second measure of connections to Geithner, which we refer to as "personal connections", identifies the number of links that Geithner has with each firm through personal relationships. We identify these links using the relationship maps published by muckety.com (run

\footnotetext{
${ }^{19}$ We have also constructed the base sample by dropping firms that rank in the top $5 \%$ and in the top $20 \%$ of those correlated with Citigroup. Our main results remain unchanged, although in the latter case only seven firms remain in the treatment group.

20 "Geithner's Calendar at the New York Fed," The New York Times, available at documents.nytimes.com/geithner-schedule-new-york-fed.
} 
by independent journalists). ${ }^{21}$ The maps on muckety.com show the links for a given individual to other people or to organizations. ${ }^{22}$ We count a link between Geithner and a firm if he has a personal link with a person who is a director of the firm, or if he shares a board or similar position (e.g., trustees of the Economic Club of New York) with someone who works for the firm. ${ }^{23}$ We require that those links be active when Geithner's nomination was announced.

For example, we find a link between Geithner and American Express on muckety.com through Kenneth Chenault, chairman and CEO of American Express, who is associated with Geithner through the National Academy Foundation, where they are both directors, and through the Partnership for New York City, where Chenault is a vice chairman and Geithner is a board member. Based on this information we code personal connections for American Express as one. Descriptive statistics for this variable are reported in Row 2 of Table 1. Geithner has the greatest number of personal connections (nine) to Citigroup; in contrast, he has only one connection to Bank of America. The average number of personal connections to Geithner, conditional on a firm having at least one connection, is 2.24. Appendix Table A2 lists all of the identified personal connections between Geithner and sample firms.

To independently verify the accuracy of the information provided by muckety.com, we searched the annual reports of each company with an identified personal connection to Geithner, as well as other publicly available information. We were able to verify 52 of the 58 connections reported by muckety.com, 45 of those using the annual report filed most immediately subsequent to the Geithner nomination announcement (typically, for years ending December 31, 2008), and another seven using other sources such as Forbes and Bloomberg. Of the remaining six connections, two are confirmed to be errors and are excluded from our data. The other four are identified as legal counsel for financial firms in the sample. These have also been excluded from our data due to the difficulty of verifying the connection and because of the different nature of the connections. These exclusions leave us with a set of 52 personal connections to Geithner from 21 different financial firms (although five connected people each have two board links to Geithner). Panel B of Appendix Table A1 lists these firms and their connections.

\footnotetext{
${ }^{21}$ These data are broadly similar to what is available for emerging markets, e.g., Gomez and Jomo (1997, 1998) on Malaysia. Many connections in emerging markets are formed early in careers. Most of the Geithner connections are from his time at the New York Fed. We use muckety.com relationship maps from March 2009.

${ }^{22}$ Measuring connections in ths way is standard in the network sociology literature. See, for example, Useem (1984). Fisman et al. (2012) review the sociology literature on why board ties matter, including for the flow of information.

${ }^{23}$ Most of our data are board memberships, which are a matter of public record. However, the muckety.com coding also contains some well-known mentor/adviser relationships, with Robert Rubin and a few others.
} 
The third measure of connections to Geithner is based on firm location, under the reasonable assumption that Geithner would have greater contact with executives of firms headquartered in New York City, where Geithner was located as president of the New York Fed. This measure is a dummy variable set equal to one if the headquarters of the firm is identified as New York City in the Datastream database. Descriptive statistics are reported in Row 3 of Table 1. Forty-five of the sample firms have headquarters in New York City; these firms are listed in Appendix Table A3. All other sample firms not listed in Appendix Table A3 are listed in Appendix Table A4.

As is shown in Appendix Tables A1 and A3, there is some overlap in the three measures of connections. Of the 63 firms that have some measure of connections, nine are connected according to all three measures, ten are connected according to two of the three measures, and 44 are connected according to only one of the measures. In subsequent analysis, when regressions include our standard control variables, the number of connected firms becomes 22 (schedule), 20 (personal), and 41 (New York) due to missing data on control variables. In addition, when we focus on our base sample the number of connected firms is 12 (schedule), 8 (personal), and 34 (New York).

Rows 4 through 6 of Panel A of Table 1 report basic financial information for the sample firms as obtained from the Worldscope database for the year 2008. Size (Row 4) is reported as the logarithm of total assets, profitability (Row 5) is return on equity, and leverage (Row 6 ) is the ratio of total debt to total capital. Rows 7 through 9 report summary statistics for our primary measure of firm performance, cumulative abnormal stock returns (CARs) - the calculation of which is discussed in the next section. Rows 10 through 12 report statistics for our secondary measure of performance, percentage changes in credit default swap (CDS) spreads, which is also covered in the next section.

Panel B of Table 1 reports differences in the means of these variables between firms connected to Geithner and non-connected firms; here his schedule and personal connections are converted to a dummy variable equal to one for firms that have any connection. Row 13 of Panel B shows that connected firms are significantly larger than non-connected firms for all three measures of connections. Row 14 shows that profitability is significantly lower for connected firms, but only when we use the New York measure. Row 15 shows that leverage is higher for connected firms, but the difference is only significant for the schedule measure of connections. Panel C repeats the analysis of Panel B for the base sample. The differences reported in Panel $\mathrm{C}$ are broadly similar to those in Panel B. Because of the performance differences shown in 
Panels B and C, we control for these variables below. Finally, Panel D of Table 1 reports correlation coefficients between the explanatory variables reported in Panel A.

\section{Geithner Connections and Stock Returns}

In this section we study whether connections to Geithner, as defined in the previous section, are associated with differences in returns at the time of the announcement of Geithner's nomination. We begin by calculating returns for each firm in the sample on the relevant dates. Geithner's nomination was officially announced by President-elect Barack Obama early on Monday, November 24, 2008. However, news of his impending nomination was leaked to the press late in the trading day on Friday, November 21, 2008 at approximately 3:00 p.m. ET a time that coincides with the beginning of a stock market rally.

For the purposes of studying stock price reactions, we define event day 0 as November 21 and event day 1 as November 24, with subsequent event days corresponding to subsequent trading days. We obtain daily stock returns for each sample firm from the Datastream database. In order to more precisely delineate the response to the Geithner announcement on event day 0, we calculate returns on that day as only the returns from 3:00 p.m. until the market close at 4:00 p.m. We obtain intraday returns from the TAQ database.

\subsection{Univariate Tests}

Panel A of Table 2 compares actual returns between connected and non-connected firms in the base sample for event days 0 through 10 . Panel A shows that on event day 0 , using schedule connections, connected firms outperformed non-connected firms by 4.3 percentage points, a difference that is significant at the $5 \%$ level. Results are similar for the other measures of connections, though not statistically significant for personal connections. On event day 1 , when the nomination was officially announced, return differences are even more pronounced. Using the schedule measure, connected firms outperformed non-connected firms by 8.4 percentage points on this day. The corresponding outperformance for firms with personal connections is 9.6 percentage points, and for firms with New York connections it is 3.1 percentage points. The difference for the schedule and personal connections is significant at the $1 \%$ level, while for New York it is significant at the $10 \%$ level.

Panel A also shows that connected firms continued to outperform non-connected firms on each day through event day 10 , with the primary exception being event day $5 .{ }^{24}$ The final row

\footnotetext{
${ }^{24}$ The underperformance of connected firms on event day 5 (a day when there was a sharp market down-
} 
of Panel A reports cumulative performance for event days 0 through 10. Using the schedule measure of connections, connected firms outperformed non-connected firms by 37.1 percentage points over this period. For personal connections the difference was 46.3 percentage points, and for New York connections the difference was 29.9 percentage points. By any measure of connections, the outperformance of connected firms over this period was economically large and highly statistically significant.

Because there were large market movements during the event window, it is important to also calculate abnormal returns for the event days. Our procedure for calculating abnormal returns follows Campbell, Lo, and MacKinlay (1997). We calculate cumulative abnormal returns using the market model as follows:

$$
C A R[0, n]_{i}=\sum_{t=0}^{n} A R_{i t},
$$

where $C A R[0, n]_{i}$ is the cumulative abnormal return for firm $i$ for event days 0 through $n$. $A R_{i t}$ is calculated as

$$
A R_{i t}=R_{i t}-\left[\hat{\alpha}_{i}+\hat{\beta}_{i} R_{m t}\right]
$$

where $A R_{i t}$ is the abnormal return for firm $i$ on event day $t, R_{i t}$ is the actual return on firm $i$ for event day $t$, and $R_{m t}$ is the return on the market for event day $t$, with the market return represented by the return on the S\&P 500 index. The parameters $\hat{\alpha}_{i}$ and $\hat{\beta}_{i}$ are estimated from the following equation:

$$
R_{i t}=\alpha_{i}+\beta_{i} R_{m t}+\varepsilon_{i t}
$$

on a pre-event period of 250 trading days ending 30 days prior to event day 0. Although the choice of estimation period length is subjective, a length of 250 days corresponds to roughly one year of trading and has been used in other studies such as Jayachandran (2006) and Li and Lie (2006). The cumulative abnormal returns show the actual returns of each firm less the predicted returns of each firm based on that firm's performance relative to the market over the estimation period. ${ }^{25}$

Panel B of Table 2 compares cumulative abnormal returns between connected firms and non-connected firms in the base sample for event days 0 through 10 . In contrast to the actual returns reported in Panel A, no significant difference is reported between CARs of connected firms and non-connected firms for the one hour of event day 0. Beginning on event day

turn) applies only to actual returns. In terms of abnormal returns (discussed below), there is no significant underperformance of connected firms on event day 5 .

${ }^{25}$ We also calculated abnormal returns using a three-factor model, but the improvement in fit relative to the market model was negligible. 
1, the differences in CARs between connected firms and non-connected firms are relatively large, but not statistically significant. Significant differences in CARs increase on subsequent event days. The final row of Panel $\mathrm{B}$ shows that using the schedule measure, $C A R[0,10]$ for connected firms is higher than $C A R[0,10]$ for non-connected firms by 15.7 percentage points. The corresponding differences for the other measures are 15.8 percentage points and 11.0 percentage points, and in all cases the difference between the CARs is significant at the $1 \%$ or $5 \%$ level. We repeat the analysis of Table 2 for the full sample and report those results in Appendix Table A5. The results are fairly similar to those reported for the base sample.

Table 2 shows strong performance of connected firms relative to non-connected firms in response to Geithner's nomination as Treasury Secretary. In the tests that follow, we assess whether these results hold when controlling for other firm characteristics in a multivariate setting.

\subsection{OLS Regression Results}

To control for additional characteristics of the sample firms, we first test the relationship between connections to Geithner and cumulative abnormal returns in a regression framework. We estimate the following equation:

$$
C A R_{i}=\alpha+\beta x_{i}+\mathbf{z}_{i}^{\prime} \phi+\varepsilon_{i}
$$

where $C A R_{i}$ is either $C A R[0], C A R[0,1]$, or $C A R[0,10]$ for firm $i, x_{i}$ is a measure of connections for firm $i$, and $\mathbf{z}_{i}$ is a set of firm-level covariates for firm $i$ (such as firm size, profitability, and leverage).

The firm-level covariates are included to control for other basic firm characteristics that could have some effect on the observed relationship between connectedness and returns. A common practice in regressions of this type in previous literature is to not control for firmlevel characteristics (see, e.g., Fisman (2001), Jayachandran (2006), Fisman et al. (2012)), although Johnson and Mitton (2003) control for firm size and leverage and Jayachandran (2006) controls for firm size in robustness checks.

Results from such regressions could be confounded, however, by the differential effects of events following Geithner's nomination on firms with different characteristics. For this reason, in the regressions that follow we control flexibly for a range of firm-level characteristics and, as a further step in this direction, we will also report results from various matching estimators. In particular, firm size is included as a control because if Geithner had more 
interaction with larger firms - and Panel B of Table 1 indicates that this is the case - then the observed performance of Geithner-connected firms could be due to their size rather than to their connections. Profitability is also an important control because it is an indicator of how hard each firm had been impacted by the crisis, and it is possible that the firms that had been hit the hardest also had the most to gain from Geithner's appointment. Finally, leverage is included as an additional indicator of the vulnerability of each firm during the crisis. For all of these variables, we include cubics - i.e., the level, square, and cubed value - so as to account for potential non-linear effects.

There might be other factors causing correlation of error terms (residual returns) across firms. Unadjusted OLS standard errors would be biased in this case and could be too low. To adjust for this possibility, we estimate adjusted standard errors that account for potential cross-firm correlation of residual returns. We estimate the covariance matrix of returns using pre-event return data on a window of 250 trading days ending 30 days prior to event day 0 . This estimated covariance matrix is then used to calculate our standard errors, under the assumption that the pre-event covariance matrix is an appropriate estimate of the covariance matrix during the event. These adjusted standard errors should account for observed crosssectional correlation of returns between firms in our sample (see Greenwood (2005); Becker, Bergstresser, and Subramanian (2013)). We use these adjusted standard errors below.

Table 3 reports results of the estimation of equation (1). The adjusted standard errors are reported below coefficients in parentheses. The three measures of Geithner connections (schedule, personal, and New York) are tested in turn. Although there is no established standard in the literature for the appropriate length of the event window, we follow the practice of first reporting results for shorter event windows $(C A R[0]$ and $C A R[0,1])$ and then a longer event window $(C A R[0,10])$. The first three columns of the table report results for the full sample with $C A R[0]$ as the dependent variable - the Citigroup bailout occurred after the first trading day and thus correlation with Citigroup is not a concern when we use $C A R[0]$. In Column 1 the coefficient on schedule connections is 0.0033 , which indicates an abnormal return of over $0.3 \%$ for each additional connection and is statistically significant at the $1 \%$ level. So, for example, a firm with a number of connections equal to the sample average, conditional on being connected (4.96 connections in the full sample), would have had an abnormal return of roughly $1.6 \%$ on average, relative to non-connected firms during the last hour of trading on November 21. The coefficient on personal connections is significant at the $5 \%$ level and indicates an abnormal return of over $0.7 \%$ for each additional personal connection, which also 
implies a similar average abnormal return of about 1.6\% for the average connected firm (which has 2.24 personal connections in the full sample). The coefficient on New York connections is significant at the $10 \%$ level and indicates that firms with New York connections had abnormal returns of $1.3 \%$ relative to non-connected firms. ${ }^{26}$

Columns 4 through 6 of Table 3 report results for $C A R[0,1]$, focusing on the base sample. The coefficients on schedule connections and personal connections are both positive and significant at the $1 \%$ level. The magnitude of the coefficient on schedule connections indicates that each additional interaction with Geithner during his tenure at the New York Fed is associated with an abnormal return of $1.1 \%$ for event days 0 and 1 combined. This implies an abnormal return of about $3.5 \%$ for the average connected firm (which has 3.16 schedule connections in the base sample). The coefficient on personal connections indicates an abnormal return of $5.0 \%$ for each additional personal connection between Geithner and the firm, and thus an abnormal return of about $8.8 \%$ for the average connected firm (which has 1.75 personal connections in the base sample). The coefficient on New York connections is not statistically significant.

The last three columns of Table 3 report results for the estimation of equation (1) on the base sample with $C A R[0,10]$ as the dependent variable. In these three columns the coefficient on Geithner connections is positive for all measures and significant at the $1 \%$ level for the personal and New York measures. Compared to the quantitative magnitudes for $C A R[0,1]$, the coefficients on the personal and schedule measures are similar, but the coefficient on the New York measure is much larger, showing an abnormal return of $10.8 \%$ for connected firms.

In summary, Table 3 reports economically meaningful and statistically significant cumulative abnormal returns for Geithner-connected firms following the announcement of his nomination as Treasury Secretary, for both short and long event windows. ${ }^{27}$

\subsubsection{Robustness Checks for OLS Results}

We perform additional tests to assess the robustness of our baseline results reported in Table 3, and these are presented in Table 4. In this table and in others that follow, we suppress reporting of the coefficients of control variables for brevity, although we always include the control variables (up to cubics in size, profitability, and leverage) in all specifications. To save space we do not report results for New York connections in this table.

\footnotetext{
${ }^{26}$ We do not report results for the base sample for $C A R[0]$, but the corresponding coefficients in the base sample are positive for all three measures and statistically significant for the New York measure.

${ }^{27}$ We do not report results for the full sample for $C A R[0,1]$ and $C A R[0,10]$, but the corresponding coefficients in the full sample are generally larger and more precisely estimated than those reported for the base sample.
} 
We first address the question of whether Geithner-connected firms performed well after the announcement of his nomination because of their personal connections to Geithner or because Geithner's appointment represented a signal that economic policy would be sensible. We get at this question in four ways.

Our first set of robustness checks controls for the vulnerability of firms to the macroeconomic conditions prevailing at the time. These include the extent to which firms' stock prices declined in the immediate aftermath of the collapse of Lehman Brothers in September 2008 as a measure of how badly a firm might have suffered from the uncertainty or the fire sales that a further collapse could have triggered (and that Geithner's policies might have been anticipated to mitigate). Specifically, we calculate the cumulative abnormal return starting on the day of Lehman's bankruptcy (Monday, September 15, 2008, is day 0 for this event) and for the following four days, which comprises the entire trading week.

As a second way to measure crisis vulnerability, we control for whether the firm is a deposittaking institution, as such institutions may have differed in vulnerability to the crisis from other financial firms. Using Worldscope data, we create a dummy variable for positive deposits. Finally, we also control for whether firms had already received TARP funding prior to the announcement of Geithner's nomination, which can act as another proxy for the systemic importance of a firm. TARP-approved firms were unlikely to collapse.

Columns 1 and 2 of Table 4 report results controlling for all three of these proxies for crisis vulnerability. The results are similar to our baseline results, with the exception that results for $C A R[0,10]$ are somewhat weaker (Panel $\mathrm{C}$ ). The coefficients on the proxies for crisis vulnerability (not reported in the table) are not always statistically significant in the regressions, but the coefficients on the Lehman bankruptcy CAR and the deposit-taking dummy are generally negative, and the coefficient on the TARP-funding dummy is generally positive.

In Columns 3 and 4 we control for how firms responded to the announcement in early October that TARP funds would be used to recapitalize large banks. This decision was generally regarded as the best of the available alternatives - so the response to this announcement offers another plausible way to control for how firms were affected by sound policy decisions. This decision was made public on Monday, October 13, with the announcement just after the stock market closed - although it followed a meeting of top bankers at the Treasury Department that was public knowledge. Similar European recapitalization plans had been unveiled over the weekend, and this further contributed to the expectation that something similar would happen in the United States. We calculate $C A R[0,1]$ for this event with October 13 as day 
0 and October 14 as day 1. Columns 3 and 4 show that controlling for this variable in our regressions does not alter the main results. The effect of being connected to Geithner remains statistically significant.

As a third approach we recalculate abnormal returns using an estimation window that is focused on the turbulent period surrounding Lehman's collapse - so our measure of expected returns uses betas that reflect the response of each firm to market movements during this particular period. We calculate abnormal returns as described above, except that the estimation period begins two weeks prior to the Lehman collapse (Monday, September 1, 2008) and ends three weeks after the Lehman collapse (Friday, October 3, 2008), when Congress ultimately approved EESA (which included TARP). Results using this measure of abnormal returns are reported in Columns 5 and 6. The results show that the coefficients on Geithner connections are significant across all three panels in this specification and are all larger in magnitude than the coefficients in our baseline results.

As a fourth approach, in Columns 7 and 8, we control more directly for the exposure of financial firms to "toxic assets". We measure exposure to toxic assets using data from Erel, Nadauld, and Stulz (2013). We use their measure of holdings of mortgage-backed and assetbacked securities (scaled by total assets) compiled from the Consolidated Financial Statements for bank holding companies, as reported by the Federal Reserve Board of Governors. We use data as of December 2008, and the variable is available for only 196 insured banks in our sample. When controlling for this variable, the coefficient on Geithner connections is highly significant in all three panels. The coefficient on "toxic assets" (not reported in the table) is always positive and usually significant. ${ }^{28}$

In our next robustness checks we test for the influence of the largest firms and extreme observations on our results. Although we control flexibly for firm size throughout our analysis, in Columns 9 and 10 we take another approach by limiting the sample to only the top size decile of sample firms, thereby creating a subsample that is more homogenous in terms of size. The coefficient on Geithner connections is positive and statistically significant in four out of six cases in this subsample.

In Columns 11 and 12 we exclude firms that the administration deemed to be of systemic importance, in that they were later included in the government-administered stress tests. The

\footnotetext{
${ }^{28}$ We have also examined the effect of including interactions between our various measures of exposure to a further decline in asset prices (i.e., the control variables in Columns 1 through 4 and Columns 7 and 8) with the Geithner connection variable. There are in general no robust and consistent interaction effects between these exposure variables and connections to Geithner.
} 
firms that the government included in the stress tests (i.e., the Supervisory Capital Assessment Program, SCAP) were those viewed in early 2009 as systemically important by the administration - and thus may have been more likely to benefit from bailouts similar to the one provided to Citigroup or from other policies. ${ }^{29}$ These estimates are positive and significant in all but one case. In Columns 13 and 14 we check for the influence of outliers by excluding firms with extreme CARs, defined as those larger than the 99th percentile or smaller than the 1st percentile. The Geithner coefficient is significant in all but one case in this specification.

As an additional robustness test, we consider whether results obtained for the schedule measure of connections are robust when we calculate the number of connections using only Geithner's appointments from the year 2007. By 2008, the initial stages of the crisis were underway, so Geithner may have had an increased number of meetings during this time with firms affected by the crisis. Using only 2007 appointments as the schedule measure of connections puts the focus on pre-crisis relationships. The results using the 2007 measure are reported in Column 15. As with our baseline results, the coefficient on schedule connections is significant at the $1 \%$ level for $C A R[0]$ and $C A R[0,1]$, but not for $C A R[0,10]$.

To summarize, in the robustness checks in Table 4 the Geithner connection coefficients generally retain statistical significance, although there are some exceptions. The magnitudes of the coefficients vary but are often larger than those reported in the corresponding baseline results in Table 3. Table 4 indicates the positive relation between Geithner connections and abnormal returns surrounding his nomination announcement is fairly robust in OLS specifications. ${ }^{30}$

We also estimate similar results using various matching estimators. This includes propensity score matching estimators in which firms were matched just on size; on primary control variables (size, profitability and leverage); and on primary control variables plus other control variables (TARP participation dummy, deposit-taking dummy, and the CAR surrounding the Lehman collapse). It also includes a nonparametric matching estimator, which estimates the impact of connections on cumulative abnormal returns separately across 64 cells created according to the covariates values and then combines them using the inverse standard errors

\footnotetext{
${ }^{29}$ This excludes the following 17 firms from our sample: American Express, Bank of America, BB\&T, Bank of New York Mellon, Capital One, Citigroup, Fifth Third Bank, Goldman Sachs, JPMorgan Chase, Key Corp., Morgan Stanley, PNC Financial Services, Regions Financial, State Street, SunTrust, U.S. Bancorp, and Wells Fargo. The other two SCAP participants, GMAC and MetLife, are not part of our sample.

${ }^{30}$ To briefly summarize the results for the unreported New York measure of connections, it is statistically significant (with the expected sign) in the following specifications: in Panels A and C when controlling for crisis vulnerability, in Panels $\mathrm{A}$ and $\mathrm{C}$ when controlling for the TARP capital injections, in all three panels when using the Lehman collapse beta, in Panel B when controlling for toxic assets, in Panel C when using the top size decile only, in Panels $\mathrm{A}$ and $\mathrm{C}$ when excluding systemically important firms, and in Panels $\mathrm{A}$ and $\mathrm{C}$ when excluding outliers.
} 
of the estimates as weights. These results, which are reported in Appendix Table A6, show a similar pattern to that found in our other robustness checks.

\subsection{Synthetic Matching Methodology}

The results presented so far - and most event studies of this type - implicitly assume that the differences between the treatment group (Geithner-connected firms) and the control group (non-connected firms) can be captured by a combination of the excess return calculation and the covariates included in the regression model. But connected and non-connected firms may be different in other ways, which might be, at least partially, responsible for our results.

As a complementary approach to address these concerns, we turn to the method of synthetic matching developed in Abadie and Gardeazabal (2003) and Abadie, Diamond, and Hainmueller (2009). The main idea of this method is to construct a synthetic match for each firm in the treatment group (i.e., firms connected to Geithner) by using the firms in the control group in such a way that the synthetic firm has similar behavior to the actual firm before the event of interest. In contrast to the OLS results with flexible controls and the propensity score matching and nonparametric estimates discussed above, which compare firms that are similar in terms of the covariates, this approach compares firms that are similar in terms of the behavior of their pre-event abnormal returns.

The effect of the event can be measured as a function of the difference between the behavior of the firm and its synthetic match after the event. Abadie, Diamond, and Hainmueller (2009) show that a primary reason to use this method is to control for the effect of unobservable factors that have an impact on the common time trend in the treatment and control groups.

Most previous papers employ synthetic matching for the case of one entity in the treatment group and one intervention. Since our sample includes many connected firms, we extend this method for the case of many firms in the treatment group. As we explain below, inference is based on confidence intervals we construct from the distribution of the "Geithner effect" for placebo treatment groups on Geithner's nomination. ${ }^{31}$

More formally, our synthetic matching procedure is as follows. First, we divide the firms into treatment and control groups according to our measures of connections to Geithner. Then we construct a synthetic match for each firm in the treatment group by solving the following

\footnotetext{
${ }^{31}$ These intervals are constructed for testing the hypothesis of whether the effect of Geithner connections is zero or not - and are thus not standard confidence intervals.
} 
optimization problem:

$$
\forall i \in \text { treatment group },\left\{w_{j}^{i *}\right\}_{j \in \text { Control Group }}=\underset{\left\{w_{j}^{i}\right\}_{j \in \text { Control Group }}}{\arg \min } \sum_{t \in \text { Estimation Window }}\left[R_{i t}-\sum_{\substack{j \in \text { Control Group } \\ \text { ind }}} w_{j}^{i} R_{j t}\right]^{2}
$$

$$
\text { s.t. } \sum_{j \in \text { Control Group }} w_{j}^{i}=1 \quad \text { and } \quad \forall j \in \text { Control Group }, \forall i \in \text { Treatment Group } \quad w_{j}^{i} \geq 0
$$

where $R_{i t}$ is the daily return on date $t$ and $w_{j}^{i}$ is the weight of control firm $j$ employed in the optimal weighting for firm $i$. It is important that the estimation window not include the period of intervention and it is typically selected as some period prior to the intervention. As before, we use 250 trading days ending 30 days prior to the Geithner nomination announcement as our estimation window. ${ }^{32}$ The two criteria $\left(\sum_{j} w_{j}^{i}=1\right.$ and $\left.w_{j}^{i} \geq 0\right)$ imply the return for firms in the treatment group belong to convex combinations of returns for firms in the control group.

After finding the optimal weights through iteration for each firm in the treatment group, the return for the synthetic firm is constructed as:

$$
\widehat{R_{i t}}=\sum_{j \in \text { Control Group }} w_{j}^{i} R_{j t}
$$

and the abnormal return is computed as the difference between the actual return and the synthetic firm return $\left(\widehat{R_{i t}}\right)$.

To estimate the effect of intervention, we compute:

$$
\widehat{\phi}(\tau, k)=\frac{\sum_{i \in \text { Treatment Group }} \frac{\sum_{t=0}^{k} R_{i t}-\widehat{R_{i t}}}{\widehat{\sigma}_{i}}}{\sum_{i \in \text { Treatment Group }}{\frac{1}{\widehat{\sigma}_{i}}}},
$$

where

$$
\widehat{\sigma}_{i}=\sqrt{\frac{\sum_{t \in \text { Estimation Window }}\left[R_{i t}-\widehat{R_{i t}}\right]^{2}}{T}} .
$$

In the above formula, $\widehat{\phi}(\tau, k)$ is the effect of intervention at date $\tau$ computed using cumulative abnormal returns of dates $[\tau, \tau+k], 1 / \widehat{\sigma}_{i}$ is a measure of goodness of the match in the estimation window, and $T$ is the length of the estimation window. This formula for the average effect of intervention on the treatment group is thus a weighted average formula, with greater weight given to better matches. This is because the difference between actual returns

\footnotetext{
${ }^{32}$ We find that the main results are robust to using other estimation windows. The results are somewhat stronger when we use estimation windows closer to Geithner's nomination starting from September 2008.
} 
and synthetic firm returns should contain more information about the intervention when we are better able to predict the return of the firms during the estimation window.

To construct the confidence intervals, we randomly draw 5,000 placebo treatment groups from the control group - with each group having the same size as the real treatment group. We compute the Geithner-connection effect for these placebo treatment groups on event days, and construct the confidence intervals for hypothesis testing of whether the coefficient is significantly different from zero. The effect of Geithner connections is significant at $5 \%$ if it does not belong to the interval that contains the $[2.5,97.5]$ percentiles of the effect of the Geithner connection for placebo treatment groups.

Table 5 presents the results from the synthetic matching estimation. Because synthetic matching requires a dichotomous definition of the treatment and control groups, we also consider two additional definitions of connections: "highly connected" firms, which are defined as those with more than two identified meetings with Geithner, and "mildly connected" firms, which are those with one or two identified meetings. ${ }^{33}$

Panel A of Table 5 presents results for the full sample in $C A R[0]$, and Columns 1 through 3 present results for all Geithner schedule connections (highly and mildly connected). Column 1 reports standard OLS results. In order to be comparable to the synthetic matching results, the connections variable is a dummy (equal to one for firms with any number of connections). We continue to adjust the OLS standard errors for pre-event correlations between firms, and the OLS regressions include cubics in size, profitability, and leverage as before. Column 1 shows that Geithner connections are associated with an abnormal return of $1.4 \%$ for the one-hour return on day 0 , and that this coefficient is statistically insignificant. Below the coefficient we report the number of significant coefficients obtained at each significance level when we test the effect of Geithner connections on 100 trading days between October 31, 2008, and April 7, 2009 (excluding key event dates), a period that does not overlap with our estimation period. The number of significant coefficients on non-event days indicates the drawback of using OLS - i.e., the Geithner connections coefficient is significant more often than would be expected.

Column 2 presents the synthetic matching results as outlined above. The coefficient on

\footnotetext{
${ }^{33}$ Appendix Table A7 reports the weights on firms in our control group for each firm in our treatment group. Our control group includes synthetic matches based on the characteristics of over 70 firms. For example, in the synthetic match for Bank of America, Wells Fargo contributes a weight of 0.30. But Wells Fargo is not a particularly good match for other firms in our treatment group - it contributes a weight of 0.19 for JPMorgan Chase but not more than a 0.06 weight for any other firm. U.S. Bancorp contributes a weight of 0.41 for PNC, but this is unusually high. The pattern for Citigroup is more common - one firm contributes a weight of 0.21 to the synthetic match, another eight firms contribute weights of between 0.08 and 0.13 , and one other firm has a weight of 0.01 .
} 
Geithner connections is smaller than in the OLS results and is not statistically significant. The number of significant coefficients shows that in the non-event-day tests, the Geithner connections coefficient is significant with a frequency that is much closer to what would be expected in theory (e.g., at the $5 \%$ level, four times in a test window of 100 trading days). This makes us more confident that in the synthetic matching method we are isolating the true effect of Geithner connections rather than the effect of some other correlation among Geithnerconnected firms (which would have led to more frequent rejections on non-event days).

Column 3 presents "corrected" synthetic matching results in which for our inference procedure we eliminate firms for which we do not have a good synthetic match, defined as the firms in the control group with $\widehat{\sigma}$ more than $\sqrt{3}$ times the average $\widehat{\sigma}$ for the real treatment group firms. ${ }^{34}$ Although the formula used in the synthetic matching method already gives greater weight to firms with better matches, we present the corrected results as a robustness check to ensure that our confidence intervals are appropriate. The corrected results are similar to the uncorrected results in Column 2. Columns 4 through 6 present a similar set of results for the "highly connected" indicator, and Columns 7 through 9 for the "mildly connected" indicator. As expected, the results are stronger for highly connected firms. Overall, Panel A suggests that the effect of Geithner connections on the one-hour day 0 returns is positive but not statistically significant once the synthetic matching adjustments are made.

Panel B of Table 5 repeats the tests of Panel A but for our base sample in $C A R[0,1]$. These tests show a much stronger effect of Geithner connections, even in the synthetic matching results. Column 2 shows that Geithner connections are associated with an abnormal return of $6.0 \%$, which is economically sizable and statistically significant at the $1 \%$ level. As expected, the results are even stronger for highly connected firms relative to mildly connected firms.

Finally, Panel $\mathrm{C}$ repeats the results for $C A R[0,10]$. The coefficients in Columns 2 and 3 indicate a $12.4 \%$ abnormal return associated with Geithner connections. Once again the matching estimate for highly connected firms is larger than for mildly connected firms. ${ }^{35}$ Taken as a whole, Panels $\mathrm{B}$ and $\mathrm{C}$ show that the synthetic matching methodology confirms the presence of a positive and significant effect of Geithner connections at horizons longer than the

\footnotetext{
${ }^{34}$ For both the schedule and personal measures, all connected firms have a relatively good synthetic match, so the main effect of changing the cutoff is to change the estimated confidence intervals and not the estimated coefficient. We have tried various values for this parameter, including 1 (which eliminates all the firms with $\widehat{\sigma}$ larger than the average of $\widehat{\sigma}$ for firms in the treatment group ), $\sqrt{3}$, and values larger than $\sqrt{3}$. The larger the cutoff, the closer the estimates are to uncorrected synthetic matching. Our results are not sensitive to this range of cutoff values.

${ }^{35}$ In Panel C, the Geithner connections coefficient tends to have more significant coefficients in the non-eventday tests, relative to the shorter-horizon CARs.
} 
one-hour day 0 returns.

\subsubsection{Robustness Checks for Synthetic Matching}

Table 6 presents robustness checks for the synthetic matching results, focusing on $C A R[0,1]$. In Panel A, we use the financial crisis estimation window (from September 1, 2008 to October 3, 2008) as reported above in the OLS robustness checks (see Columns 5 and 6 in Table 4). The main results are similar to those presented in Panel B of Table 5. The primary difference is that the effect is stronger for highly connected firms while it is no longer significant for mildly connected firms. Panel B uses the personal measure of connections. In these regressions the coefficient on Geithner connections is significant at the $5 \%$ level for highly connected firms. (In Panels B and D, "highly connected" is defined as more than one connection because there are fewer connections per firm using these definitions of connections.)

In Panel C, we use the New York measure of connections to Geithner. Again the results show the estimated Geithner connection coefficient is statistically significant, although the size of the coefficient is smaller than with the other measures. This could be due to attenuation bias since having headquarters in New York is a noisier measure of connections to Geithner. ${ }^{36}$ In Panel D we use just information from Geithner's 2007 schedule to create the connections variable and find that the synthetic matching results are robust to this change.

In robustness checks not reported in the table, we have also examined whether our results (OLS or synthetic matching) are dependent upon any single Geithner-connected firm. As the number of Geithner-connected firms is relatively small, particularly in the base sample, it is not surprising that in some specifications the significance of the results is altered when one observation is excluded from the sample. We find that the connected firm that has the most impact when dropped from the sample is Blackstone Group. Geithner's connections to Blackstone were strong, as evidenced by his personal and schedule connections (see Appendix Table A1) and by the fact that Peter G. Peterson (co-founder and Senior Chairman of Blackstone until December 31, 2008) was chairman of the board of directors of the New York Fed when Geithner was picked to head that institution. Excluding Blackstone Group from the sample negatively impacts the significance of the OLS results (but not the synthetic matching results) for $\operatorname{CAR}[0,1]$ in the base sample, both because the point estimates change somewhat and because confidence intervals also widen when a connected firm is excluded from the sample.

\footnotetext{
${ }^{36}$ In an additional robustness check, we repeated our analysis just within the sample of New York firms. In this case again, Geithner-connected firms had significantly higher abnormal returns.
} 
Excluding Blackstone has less impact on the CAR $[0,10]$ results, and no impact on whether coefficients are significant in the CAR $[0]$ results or in the CDS results (reported in the next section). Our robustness checks also show that there are occasions when excluding a particular firm from the sample strengthens the results by making coefficients that are otherwise insignificant become significant. Across all specifications, the balance of the effect from dropping individual firms is roughly equal - i.e., a handful of results become insignificant and a handful become significant. Our CDS results are not affected by dropping any individual firm. ${ }^{37}$

Table 7 provides our first falsification exercise. It investigates whether the positive response of Geithner-connected firms is due to mean reversion of returns prior to the nomination announcement, perhaps due to a Citigroup downturn preceding its November 2008 bailout. We test whether Geithner connections were significant in the days before the announcement using, in turn, $C A R[-1,0]$ in Panel A, $C A R[-5,0]$ in Panel $\mathrm{B}$, and $C A R[-10,0]$ in Panel C. In Columns 1 through 3 of Table 7 we present results for schedule connections. These columns show that there is a negative trend for Geithner-connected firms prior to the announcement, but none of the estimates is statistically significant. In Columns 4 and 5 we present results comparable to Column 1, but for personal and New York connections. Again, the pre-trend is negative, but not statistically significant except for $C A R[-10,0]$ for New York connections.

In Figure 1 we show the pre-trend of the effect of Geithner connections graphically. The figure shows the coefficient on Geithner connections for $C A R[x, x+1]$ for each trading day $x$ in the month of November 2008. The coefficients reported are synthetic matching results for the base sample. Panel A shows results for all connected firms, and Panel B shows results for highly connected firms. Each panel also reports confidence intervals for hypothesis testing for $C A R[x, x+1]$ at $1 \%, 5 \%$, and $10 \%$ levels. Visually, the figures do not demonstrate any consistent pattern of negative coefficients prior to the nomination event, particularly in Panel B. The figures also show that the nomination event stands out as the most statistically significant event during the period, being the only day with significance at the $1 \%$ level. Panel B in particular shows no pre-trend as the Geithner connection coefficient lies inside the confidence intervals for the entire period before the nomination. Together, Table 7 and Figure 1 suggest that the positive reaction of Geithner-connected firms to the nomination announcement was not just a reversal of previous trends.

\footnotetext{
${ }^{37}$ As a robustness check, we also performed synthetic matching for CAR $[0,1]$ for the sample of deposit-taking firms and for the sample of non-deposit-taking firms separately. The resulting estimated coefficients for the Getihner connection are $6.7 \%$ and $6.0 \%$; both are significant at the $5 \%$ level.
} 


\subsection{CDS Spreads}

If the market perceived that benefits would accrue to Geithner-connected firms from his appointment as Treasury Secretary, then the news of his nomination should have impacted not just stock returns of connected firms but also the probability of default for connected firms as reflected in their credit default swap spreads. If market participants expected that Geithner or his associates could protect connected firms from bankruptcy or other trigger events, then one would expect CDS spreads on the debt of connected firms to fall relative to non-connected firms upon the Geithner nomination announcement.

Because data on CDS spreads are available for relatively few firms, we view CDS spreads as a secondary measure of firm performance. We obtain CDS data from the data provider Markit for every firm in the full sample with available data, which gives us a sample of 27 firms for our CDS tests. Each firm has multiple CDS listings for various maturities and contract specifications. For our tests we use CDS contracts of five-year maturities (the most common tenor) on senior unsecured debt (the most common priority level) with modified restructuring provisions (the most common provision). Summary statistics for CDS spreads are reported in row 10 of Table 1. At the time of the Geithner nomination announcement, the average spread among sample firms was 465 basis points, with a median spread of 233 basis points.

Table 8 reports estimations of equation (1) in which the dependent variable is the percentage change in the CDS spread rather than the CAR in stock prices. ${ }^{38}$ (Summary statistics for CDS spread changes are reported in rows 11 and 12 of Table 1). We report results only for the full sample, with and without Citigroup, because there are not enough firms with CDS data in the base sample to estimate the model. Panel A reports OLS results, first for the percentage change in CDS spreads on day 1, and then for the percentage change in CDS spreads from day 1 to day 10. Results are not reported for day 0 because of the unavailability of intraday quotes on CDS spreads. Included but not reported in the regressions are the same control variables from previous regressions. As in the CAR results, the standard errors in these regressions are adjusted for pre-event correlations between firms. Panel A shows that for all three measures of connections the coefficient on Geithner connections is negative whether Citigroup is included or not and for both return horizons. In the first five columns, the coefficient is statistically significant. The negative coefficient is as predicted, in that the Geithner nomination is associated with a reduction in the premium required for insurance on

\footnotetext{
${ }^{38}$ Percentage changes in spreads are more appropriate as the dependent variable than are raw changes in spreads because the magnitude of spreads varies widely among firms, particularly during the crisis period.
} 
the debt of Geithner-connected firms. As an example of interpretation of the magnitude of these effects, the coefficient of -0.014 in Column 1 indicates that each additional schedule connection is associated with a $1.4 \%$ drop in a firm's CDS spread on day 1. For an average-spread firm with five schedule connections, this would imply a fall of 33 basis points.

Panel B of Table 8 reports synthetic matching results. Again the coefficient on Geithner connections is negative in all cases, and it is statistically significant in all but two cases. In some specifications the estimated effects are particularly large. For example, in Column 9, the coefficient of -0.203 indicates that New York connections are associated with a $20.3 \%$ drop in a firm's CDS spread from day 1 to day 10 (about 99 basis points for an average-spread firm). In short, the results in Table 8 are complementary to the results for stock returns and are supportive of the hypothesis that the market expected benefits for Geithner-connected firms when the Geithner nomination was announced.

\subsection{Additional Falsification Checks}

As additional falsification checks, we investigate the effect of significant positive - and negative - news about economic policy on Geithner-connected firms at moments when Geithner did not have the same amount of influence as he could have been presumed to have as Treasury Secretary. We also look at the implications of Henry Paulson's earlier nomination as Treasury Secretary, and the value of connections to other candidates at the time of Geithner's nomination event.

First, we perform the same procedure as we do for the Geithner nomination event, but for other event windows. Specifically, we examine the effect of the Bear Stearns rescue and purchase by JPMorgan Chase in March 2008. If Geithner-connected firms are different from others and tend to respond more to certain types of financial or macroeconomic policy, we may expect them to outperform others during this event window also. In particular, in this instance, there was market concern that the failure of Bear Stearns would cause market disruption or some form of contagion. The Federal Reserve became involved in helping JPMorgan acquire Bear Stearns, including by providing some insurance against losses that might occur on mortgage-related securities. ${ }^{39}$

However, we find no bump up for Geithner-connected firms on or after Monday, March 17, 2008 (the purchase was announced on March 16). This is consistent with the notion that even

\footnotetext{
${ }^{39}$ As president of the Federal Reserve Bank of New York, Geithner was closely involved in the details of this deal - and the presence of Jamie Dimon, CEO of JPMorgan, on the board of the New York Fed raised some eyebrows at the time.
} 
as head of the New York Fed, Geithner was operating within a constrained environment with strong oversight - including by the Board of Governors in Washington, D.C. In addition, the overall macroeconomic situation was not viewed as dire as it became in fall 2008. There was little sense that a major crisis was approaching.

In a similar vein, we also look for a statistically significant gain in value for Geithnerconnected firms when AIG received support in September 2008, when Congress struggled to pass emergency economic legislation in late September and early October 2008, and when capital injections to big firms were announced shortly afterwards. In none of these instances did Geithner-connected firms show significant differential gains relative to other firms using the synthetic matching methodology. ${ }^{40}$

We also examine the connections of Henry Paulson, the previous Treasury Secretary, applying the same method of identifying personal connections. His only identifiable connection on muckety.com is with Goldman Sachs - where Mr. Paulson spent most of his career. On the day of Paulson's announcement (May 30, 2006), Goldman Sachs stock fell by 2.0\% (the S\&P 500 fell by $1.6 \%$ that day), and in the 10 days following the announcement, Goldman fell by $5.2 \%$ (the S\&P fell by $3.3 \%$ ). Clearly this is only one observation, but Paulson's appointment (during an economic boom) did not appear to have a positive effect on his connections, consistent with the idea that connections matter more during crisis periods.

Finally, we study the reaction of firms linked to other leading candidates for the position of Treasury Secretary. If some unobservable characteristic makes some firms both more likely to be connected to Geithner and also more likely to perform well during our event window, then we might expect the same characteristic to lead to greater connections to other candidates. If connections to other candidates also matter during the event window, this would raise questions about our interpretation. Our results in this section do not indicate such a pattern.

After Geithner, the next leading candidates in the week prior to the announcement were Lawrence Summers, Jon Corzine, Paul Volcker, and Sheila Bair. ${ }^{41}$ As of November 15, 2008,

\footnotetext{
${ }^{40}$ There was no stock market rally on the day EESA/TARP passed Congress (October 3, 2008); the S\&P return was $-1.4 \%$ that day. There was a large decline on the day that TARP did not pass the House (September $29,2008)$, with the S\&P down $-8.8 \%$. In calculating the response to capital injections, we exclude firms that received direct injections of capital.

${ }^{41}$ There are reasons why people might have expected some other candidates to follow different policies as Treasury Secretary - policies that might have been less favorable to the types of financial firms with which Geithner was connected. For example, Corzine, despite having served as chair of Goldman Sachs in the 1990s, was now the favored candidate for at least part of the labor movement. Bair favored a narrower loan guarantee program than Geithner in October, and also eventually supported the sale of Wachovia to Wells Fargo - while Geithner preferred Citigroup as a buyer. Bair also advocated for relatively more assistance for homeowners and relatively less for financial institutions. Volcker's primary reputational attribute was the idea that he was willing to make hard choices for the good of the country, including inflicting pain when necessary, a reputation
} 
the probabilities of each candidate obtaining the job, according to Intrade's prediction market, were $45 \%$ for Geithner, $26 \%$ for Summers, $10 \%$ for Corzine, $9 \%$ for Volcker, and $8 \%$ for Bair. ${ }^{42}$ We follow the procedure discussed above, using data from muckety.com, to find personal connections to firms for these candidates. We list the firms connected to the other candidates and the nature of those connections in Appendix Table A8.

We conduct OLS regressions to test the effect of connections to all candidates on cumulative abnormal returns following the Geithner announcement. ${ }^{43}$ We employ the full sample in these tests in order to retain a reasonable number of connections to the other candidates (although we continue to exclude Citigroup from the regressions). Results of these tests are reported in Table 9. The first three columns report results with $C A R[0,1]$ as the dependent variable. For purposes of comparison, Column 1 reports coefficients for Geithner connections alone. Column 2 reports the result with the measures of Summers, Corzine, Volcker, and Bair connections included. The coefficient on Geithner connections remains significant - the coefficient increases from 0.020 to 0.023 and the standard error increases from 0.005 to 0.010 . The coefficients on connections for Summers and Corzine are positive but not significant. ${ }^{44}$ The coefficients are negative for the other two candidates.

In Column 3, we create a combined connections variable - this is a dummy variable equal to one if a firm is connected to either Summers, Corzine, Volcker, or Bair. When included in a regression with the Geithner connection variable, this variable is small and positive but far from significant (coefficient of 0.002 with a standard error of 0.007). The Geithner connections coefficient remains significant: a coefficient of 0.017 with a standard error of $0.010 .{ }^{45}$

In the final three columns of Table 9 we repeat the same structure of regressions but with the percentage change in CDS spreads as the dependent variable (this is a small sample and we do not have data on any Bair-connected firms). The coefficient on Geithner connections

earned in combating high inflation during the early 1980s. Although he had worked for Chase Manhattan in the 1950s and 1960s, and had been president of the New York Fed in the 1970s, by 2008 he was considered highly independent of any influence.

${ }^{42}$ James Pethokoukis, "Geithner Tops Odds for Next Treasury Secretary," U.S. News \& World Report, November 15, 2008.

${ }^{43}$ There is no straightforward equivalent of the synthetic matching approach in this case because there are multiple connections ("treatments").

${ }^{44}$ One might expect a negative reaction of Summers-connected firms because these firms did not get a Treasury Secretary with which they had connections. But this expectation is clouded by two factors. First, because Geithner and Summers have interacted with people in similar circles, there is a large overlap between Geithner connections and Summers connections (correlation =0.87). Second, on the day of Geithner's announcement as Treasury Secretary, Barack Obama also announced Summers as his choice for director of the National Economic Council. Summers would still have been expected to have major influence over economic decisions.

${ }^{45}$ We find similar results when we include connections to other potential candidates one by one, but this is a less compelling specification from a theoretical perspective, and we do not report the details here. 
is negative and significant in Columns 4, 5, and 6, again indicating that the market expected benefits specifically for Geithner-connected firms.

When included separately, the coefficients are positive and significant for Corzine- and Volcker-connected firms; the coefficient on Summers-connected firms is negative but not significant. ${ }^{46}$ When we combine all non-Geithner connections in Column 6 , this variable is positive (and thus opposite-signed) and significant. In this case, the Geithner effect is twice the magnitude as in Column 4 (-0.070 compared with -0.035), although the standard error also doubles, reflecting some degree of multicollinearity in the smaller CDS sample.

Overall, the falsification exercises reported in this subsection do not suggest that we are spuriously capturing the reaction of Geithner-connected firms to major events (unrelated to the nomination of Timothy Geithner). Nor are we picking up the response of a certain type of firm that tends to be both highly connected to leading figures and more likely to benefit from certain kinds of (potentially) sound macroeconomic policies that Timothy Geithner may have been expected to pursue. Our results also suggest that the timing of Geithner's appointment, in the midst of the crisis, was crucial to our finding that connections matter - as we do not find similar reactions to the announcement of Henry Paulson as Treasury Secretary.

\section{Geithner's Tax Problems}

A secondary event related to Geithner's nomination as Treasury Secretary allows us to further test the relation between Geithner connections and firm value. On Tuesday, January 13, 2009, the Senate Finance Committee publicly disclosed that Geithner had failed to pay over $\$ 34,000$ in taxes while an employee of the International Monetary Fund. This disclosure cast doubt on whether Geithner would be confirmed by the Senate. If the market expected Geithnerconnected firms to derive value from his position as Treasury Secretary, then this event should have been associated with negative stock returns for Geithner-connected firms, at least to the extent that the market believed that Geithner's confirmation was truly in jeopardy.

To measure the impact of this news on Geithner-connected firms, we define event day 0 as January 14, 2009, because the Senate Finance Committee announcement was made after the market closed on January 13, 2009. As for the end of the event period, it is impossible to determine exactly when it became clear to most market participants that Geithner would be confirmed, despite the tax issue. We examined all articles concerning Geithner and his taxes

\footnotetext{
${ }^{46}$ The samples for stock prices and for CDS spreads are very different - hence the difference in results between Columns 1 through 3 and 4 through 6 , e.g., for Corzine connections.
} 
appearing in The Wall Street Journal, beginning on January 14. The first article to predict that Geithner would be confirmed appeared on Wednesday, January 21, or event day $4 .{ }^{47}$ (The markets were closed on Monday, January 19.)

We first perform univariate tests in which we compare actual returns between connected and non-connected firms for event days 0 through 4 . In these tests we alter the base sample to also exclude the top $10 \%$ of firms based on return correlation with Bank of America, as the Geithner tax event occurred shortly after a new Bank of America bailout was announced. We find that from event day 0 through event day 3 , using the schedule measure of connections, connected firms underperformed non-connected firms by 7.9 percentage points, a difference that is significant at the $5 \%$ level. This result is consistent with a loss of value for Geithner-connected firms due to his tax issues. Personal connections and New York connections demonstrate this same underperformance, although the results are not statistically significant using these measures of connections. We also find that the fortunes of connected firms reversed on event day 4, when Geithner's confirmation appeared to be solidified, as connected firms outperformed non-connected firms on this day. The positive abnormal returns on event day 4 are statistically significant for two of the three mesaures of connections.

We perform similar univariate tests for actual returns for the full sample, as well as for cumulative abnormal returns for both the base sample and the full sample. These sets of results show a similar pattern of negative and significant returns through day 3 that tend to reverse on day 4, although there are exceptions to this pattern. Generally speaking, the pattern is stronger and more statistically significant when using the full sample rather than the base sample, and the pattern is weaker when using cumulative abnormal returns rather than actual returns. Appendix Table A9 presents all of these results in detail. Overall, the pattern of returns in the univariate results is consistent with the hypothesis that Geithner's tax problems created a negative shock to Geithner connections, and that concern over the news dissipated after a few days, particularly on event day 4 .

We also estimate the effect of Geithner connections during his tax problems in a regression framework. We estimate equation (1) for the tax event, including all standard control variables as in our previous regressions. The OLS results show that Geithner connections tend to be associated with negative returns when Geithner's tax problems were disclosed, though these estimates are less precise than our main results and often are not significant. In some cases

\footnotetext{
${ }^{47}$ Deborah Solomon, "The Inauguration: Tax Issue Won’t Derail Geithner," The Wall Street Journal, January 21, 2009.
} 
the coefficient on Geithner connections is positive, particularly for New York connections. The synthetic matching results are more consistent with the univariate results, as the coefficient on Geithner connections is almost always negative and often significant. Appendix Table A10 presents these regression results in detail. Overall, although the regression results are fairly imprecise, the univariate and regression results together are consistent with the hypothesis that connections to Geithner were a source of value for connected firms, but the market may have correctly anticipated that tax issues would not prevent Geithner's confirmation.

\section{After the Announcement}

The results above imply that market participants expected a Geithner Treasury to benefit financial institutions that had connections to the incoming Secretary. Even without specifying a precise channel of influence, the finding that people - via the markets - thought that connections to the incoming Treasury Secretary would pay off in financial terms is itself noteworthy.

There is a further question that still deserves consideration, however: whether the expectations revealed by this event study were sensible. In particular, did the "social connections meets the crisis" view make sense around the time of Timothy Geithner's nomination as Treasury Secretary? By its nature, this is not a question that can be answered conclusively, but at least some pieces of evidence - which we now discuss - are consistent with this interpretation.

\subsection{Hiring}

Geithner hired a number of key people from prominent Wall Street firms, including from those with which he had a strong connection. Mark Patterson, a former Goldman Sachs lobbyist, became his chief of staff. Lee Sachs, previously with Bear Stearns and Mariner Investment Group, became a senior adviser to Geithner with responsibility for helping to design financial sector policies. Herb Allison, who was brought in to run TARP as assistant secretary, was formerly a senior executive at Merrill Lynch and TIAA-CREF. David Miller, a Goldman Sachs alumnus, became TARP's chief investment officer; as a member of the Paulson Treasury, he had been involved in the bailouts of late 2008 and early $2009 .{ }^{48}$

Not all of Geithner's staff came from Wall Street. For example, Neal Wolin, whose private sector experience was at The Hartford, an insurance company, became Deputy Treasury Secretary. However, Wolin had previously worked in the Rubin-Summers Treasury, so this is

\footnotetext{
${ }^{48}$ Michael J. De La Merced, "Treasury's Warrior at the Negotiating Table," The New York Times, January 31, 2011.
} 
consistent with Geithner hiring people from within his personal network.

\subsection{From Nomination to Confirmation}

Geithner's nomination was leaked to the press on November 21, 2008, but he was not confirmed by the Senate until January 26, 2009. In the interim, he undoubtedly had influence on policymaking within Treasury, both as president of the New York Fed and the likely incoming Treasury Secretary. This period was marked by two high-profile interventions: the bailout of Citigroup in late November and the bailout of Bank of America in January. These bailouts represented major emergency subsidies from the Treasury Department. In each case, the bank received additional TARP capital, but the government also agreed to guarantee a pool of assets against declines in value. These guarantees were effectively a non-transparent and underpriced form of insurance (compared with what such guarantees would have cost in the free market). ${ }^{49}$

While the Citigroup bailout (November 2008 edition) was always understood as a means of saving the bank, it was reported in January 2009 that the Bank of America bailout had been promised in exchange for the bank agreeing to complete its acquisition of Merrill Lynch, then the third-largest investment bank on Wall Street. In April 2009, an investigation by New York Attorney General Andrew Cuomo further revealed that then-Treasury Secretary Henry Paulson had threatened to replace Ken Lewis as CEO of Bank of America if he refused to complete the Merrill acquisition. These interventions clearly benefited Citigroup, which otherwise might have failed, and Merrill Lynch, which otherwise would almost certainly have failed. Whether they benefited Bank of America is another question that is difficult to answer. As losses mounted at Merrill in December 2008, it may have become rational for Bank of America to walk away from the planned acquisition; the subsidy provided by the government in the form of the January bailout may or may not have compensated it for those additional losses. The net effect was to press a North Carolina-based bank (with relatively small investment banking operations) to complete its acquisition of a New York-based investment bank.

\subsection{Rescue Programs Under Geithner}

Geithner's Capital Assistance Program (CAP) was one mechanism for providing capital to banks that needed it. The terms of the CAP were generally favorable to the recipients of capital, but it is not obvious whether the program was more or less favorable than the Capital

\footnotetext{
${ }^{49}$ According to the TARP Congressional Oversight Panel, the Citigroup bailout contained an implicit subsidy of $50 \%$, as compared to a subsidy of $22 \%$ in the TARP Capital Purchase Program. Congressional Oversight Panel, "February Oversight Report: Valuing Treasury's Acquisitions," February 6, 2009.
} 
Purchase Program that was created by Paulson in October 2008. Investments under the CAP were in convertible preferred stock, which has the potential to dilute existing bank shareholders. However, the conversion option was held by the bank, not by Treasury. ${ }^{50}$

At the same time, the CAP was coupled with bank stress tests that were conducted in March and April 2009 on 19 major financial institutions. Of the 19 institutions, ten were found to need additional capital. The complexity of bank balance sheets, and the process by which the test results were released, left significant room for firm-specific negotiation. At least Citigroup, Bank of America, PNC Financial, and Wells Fargo negotiated with the government over the final stress test results. According to The Wall Street Journal, "The Federal Reserve significantly scaled back the size of the capital hole facing some of the nation's biggest banks shortly before concluding its stress tests, following two weeks of intense bargaining." 51 This created latitude for regulators to take actions that might favor some banks over others. ${ }^{52}$

The Public-Private Investment Program (PPIP) delivered on the expectation that Geithner would revive Paulson's original plan to purchase banks' troubled assets. The PPIP offered non-recourse government loans and FDIC loan guarantees to private sector investors willing to acquire troubled assets. This plan effectively provided a subsidy to these investors in order to increase their willingness to pay for the assets and help close the gap that separated bids and asks in the open market. Therefore, the plan aimed to benefit banks holding large amounts of troubled assets, but it also benefited buy-side institutions such as hedge funds, private equity firms, and asset management firms that could participate in the program. According to Neil Barofsky, then Special Inspector General for TARP, "PPIP had been designed by Wall Street, for Wall Street" - in particular, by BlackRock, the Trust Company of the West Group, and PIMCO, suggesting that there was some potential for well-connected financial institutions to influence government policy at key moments during the financial crisis. ${ }^{53}$

Following Geithner's confirmation, Treasury engaged in fewer firm-specific interventions than in the November 2008-January 2009 period. The two big exceptions were the Citigroup bailout on February 27, 2009, and the AIG bailout on March 2, 2009.

\footnotetext{
50 "Capital Assistance Program, Summary of Mandatorily Convertible Preferred Stock ('Convertible Preferred') Terms," Treasury Department fact sheet, February 25, 2009, available at www.treasury.gov/presscenter/press-releases/Documents/tg40_captermsheet.pdf.

${ }^{51}$ David Enrich, Dan Fitzpatrick, and Marshall Eckblad, "Banks Won Concessions on Tests," The Wall Street Journal, May 9, 2009.

${ }^{52}$ For example, the decision to base capital requirements on Tier 1 common capital rather than tangible common equity affected different banks differently, arguably hurting Wells Fargo the most. Ibid.; Felix Salmon, "Chart of the Day: Common Capital vs. TCE," Reuters, May 9, 2009.

${ }^{53}$ Barofsky (2012), p. 129. Bloomberg reports that BlackRock did very well on its TTIP-related investments, http://www.bloomberg.com/news/2012-12-05/blackrock-liquidates-ppip-fund-earning-u-s-treasury-24-.html.
} 
In late February 2009, there were signs that Citigroup was facing another wholesale bank run, most evident in its declining stock price, the falling price of its subordinated bonds, and the rising price of credit default swap protection on its senior bonds. Geithner's initial proposal was to split Citigroup into a "good bank" and a "bad bank". According to Sheila Bair, this would have transferred all of the bank's losses to the FDIC, "without imposing any loss absorption on shareholders and bondholders," and letting "Citi's private stakeholders take all of the upside" (Bair (2012), p. 167). The government's eventual response was to engineer a preferred-forcommon swap including both the Treasury Department and several large investors in Citigroup; however, many of the preferred shareholders and subordinated debt investors were not required to convert their investments into common stock. ${ }^{54}$ The bank's common stock price fell on the news, so presumably the market was expecting an even more generous bailout. ${ }^{55}$

After a disastrous fourth quarter of 2008 that threatened AIG's viability as a going concern, the government improved the terms on its existing preferred stock and AIG's credit line, and invested more cash in exchange for more preferred stock. ${ }^{56}$ By this point, AIG was largely owned by the U.S. government, so the bailout was not intended to benefit AIG's shareholders; instead, its goal was to keep AIG afloat in order to minimize collateral damage to other firms. Because it was still considered solvent, AIG was able to honor its commitments to its counterparties, largely credit default swap protection it had sold to other financial institutions such as Goldman Sachs, Merrill Lynch, Bank of America, Citigroup, Wachovia, Morgan Stanley, and JPMorgan Chase. As a result of AIG being able to make its counterparties whole, these banks received more cash than they would have if AIG had failed. ${ }^{57}$

\section{Conclusion}

The announcement of Timothy Geithner as President-elect Obama's nominee for Treasury Secretary in November 2008 produced a cumulative abnormal return for financial firms with

\footnotetext{
54 "Transaction Outline," Treasury Department fact sheet, February 27, 2009, available at www.treasury.gov/press-center/press-releases/Documents/transaction_outline.pdf.

${ }^{55}$ Citigroup (along with GM and AIG) also benefited from "Notices" issued by the Treasury Department allowing the company to keep the tax benefits provided by its past net operating losses - a policy that has been contested by a number of commentators and legal scholars. See, for example, Ramseyer and Rasmussen (2011).

56 "U.S. Treasury and Federal Reserve Board Announce Participation in AIG Restructuring Plan," Treasury Department press release, March 2, 2009, available at www.federalreserve.gov/newsevents/press/other/20090302a.htm

${ }^{57}$ Goldman Sachs claimed that even if AIG had collapsed, its positions with AIG were fully hedged. Peter Edmonston, "Goldman Insists It Would Have Lost Little If A.I.G. Had Failed," The New York Times, March 20, 2009. Barofsky argues that AIG did not need to pay 100 cents on the dollar, but there was no serious attempt to negotiate a reduction in payments (Barofsky (2012), pp. 186-187).
} 
which he had a connection relative to other comparable, non-connected firms. According to our estimates, this excess return was about $6 \%$ at the close of the first full day of trading after the announcement and about $12 \%$ after ten trading days. Our findings are fairly robust and similar using different measures of connections, with flexible controls for firm size and other characteristics, and also with a synthetic matching methodology. There were subsequently abnormal negative returns for connected firms when news broke that Geithner's confirmation might be derailed by tax issues, although these returns are less precisely estimated.

It is implausible to interpret these results as evidence of Geithner being corrupted or seeking material gain. Instead, in our view, the excess returns for being connected to Geithner reflect the market's expectation that, during a period of turbulence and unusually high policy discretion, the new Treasury Secretary would need to rely on a core group of employees and a small social network for real-time advice - and that these employees were likely to be hired from financial institutions with which Geithner had connections. This motivates the "social connections meets the crisis" interpretation.

We lean towards this interpretation because our results cannot be explained by the idea that Geithner just brought a safe pair of hands to the management of the economy, or by the notion that Geithner and his advisors solely favored large, complex Wall Street firms at the expense of other financial institutions. Our results control flexibly for firm size, profitability, and leverage, and are based, therefore, on differences between connected and non-connected financial institutions of roughly the same size. Consistent with this interpretation, Geithner's Treasury initially hired key personnel from financial institutions with which he was connected, and some of the decisions of his department can be interpreted as being, at the margin, favorable to connected firms (in particular for Citigroup, on which we have the most detailed anecdotal evidence).

If our interpretation is correct, benefits to connected firms are temporary - and very much related to the crisis atmosphere of November 2008. Once policy discretion declines and the speed with which important decisions have to be taken slows down, these connections should become less important. This is consistent with Querubín and Snyder's (2013) findings from the Civil War era, where the excess wealth gains of congressmen disappear after the end of the large government expenditures and discretion. Whether this is in fact the case in the modern U.S. context remains an area for further research. 


\section{References}

Abadie, A., and J. Gardeazabal, 2003. The economic costs of conflict: a case study of the Basque country. American Economic Review 93, 113-132.

Abadie, A., A. Diamond, and J. Hainmueller, 2010. Synthetic control methods for comparative case studies: estimating the effect of California's tobacco control program. Journal of the American Statistical Association, 105, 493-505.

Akey, P., 2013. Valuing changes in political networks: evidence from campaign contributions to close congressional elections. Unpublished working paper, January.

Bair, S., 2012. Bull by the horns: fighting to save Main Street from Wall Street and Wall Street from itself. Free Press, New York.

Barofsky, N., 2012. Bailout: an inside account of how Washington abandoned Main Street while rescuing Wall Street. Free Press, New York.

Becker, B., G. Subramanian, and D.B. Bergstresser, 2013. Does shareholder proxy access improve firm value? Evidence from the Business Roundtable challenge. Journal of Law \& Economics, 56(1), 127-160.

Bertrand, M., M. Bombardini, and F. Trebbi, 2011. Is it whom you know or what you know? An empirical assessment of the lobbying process. NBER Working Paper 16765.

Bhagwati, J., 1998. The capital myth. Foreign Affairs, May.

Blanes-i-Vidal, J., M. Draca, C. Fons-Rosen, 2012. Revolving door lobbyists. American Economic Review, 102(7), 3731-48.

Campbell, J.Y., A.W. Lo, and A.C. MacKinlay, 1997. The econometrics of financial markets. Princeton University Press: Princeton, New Jersey.

Chiu, M.M., and S.W. Joh, 2004. Loans to distressed firms: political connections, related lending, business group affiliations, and bank governance. The Chinese University of Hong Kong working paper.

Dinç, I.S., 2005. Politicians and banks: political influences on government-owned banks in emerging countries. Journal of Financial Economics 77, 453-479.

Dube, A., E. Kaplan and S. Naidu, 2011. Coups, corporations, and classified information. Quarterly Journal of Economics, 126(3), 1375-1409.

Duchin, R. and D. Sosyura, 2012. The politics of government investment, Journal of Financial Economics 106, 24-48.

Erel, I., T. Nadauld, and R. Stulz, 2013. Why did holdings of highly-rated securitization tranches differ so much across banks? Review of Financial Studies, forthcoming. 
Faccio, M., 2006. Politically connected firms. American Economic Review 96, 369-386.

Faccio, M., R. Masulis, and J. McConnell, 2006. Political connections and government bailouts. Journal of Finance 61, 2597-2635.

Ferguson, T. and H.-J. Voth, 2008. Betting on Hitler - the value of political connections in Nazi Germany. Quarterly Journal of Economics 123, 101-137.

Fisman, R., 2001. Estimating the value of political connections. American Economic Review 91, 1095-1102.

Fisman, D., R. Fisman, J. Galef, R. Khurana, and Y. Wang, 2012. Estimating the value of connections to Vice-President Cheney. B.E. Journal of Economic Analysis and Policy 13, $1-18$.

Goldman, E., J. Rocholl, and J. So 2009. Do politically connected boards add firm value? Review of Financial Studies, 22, 2331-2360.

Gomez, E.T. and Jomo K.S., 1997. Malaysia's political economy: politics, patronage and profits. Cambridge University Press, First Edition.

Gomez, E.T. and Jomo K.S., 1998. Malaysia's political economy: politics, patronage and profits. Cambridge University Press, Second Edition.

Greenwood, R., 2005. Short-and long-term demand curves for stocks: theory and evidence on the dynamics of arbitrage. Journal of Financial Economics 75(3), 607-649.

Igan, D., P. Mishra, and T. Tressel, 2011. A fistful of dollars: lobbying and the financial crisis, NBER Macro Annual, Volume 26, 195-230.

Igan, D. and P. Mishra, 2012. Three's company: Wall Street, Capitol Hill, and K Street, unpublished, August.

Jayachandran, S., 2006. The Jeffords effect. Journal of Law and Economics 49, 397-425.

Johnson, S. and J. Kwak, 2011. 13 bankers: the Wall Street takeover and the next financial meltdown, Vintage Books: New York.

Johnson, S. and T. Mitton, 2003. Cronyism and capital controls: evidence from Malaysia. Journal of Financial Economics 67, 351-382.

Khwaja, A.I. and A. Mian, 2005. Do lenders favor politically connected firms? Rent provision in an emerging economy. Quarterly Journal of Economics 120, 1371-1411.

Li, W., and E. Lie, 2006. Dividend changes and catering incentives. Journal of Financial Economics 80, 293-308.

Mian, A., A. Sufi, and F. Trebbi, 2010. The political economy of the U.S. mortgage default crisis, American Economic Review, 100(5), 1967-98. 
Querubín, P. and J.M. Snyder, Jr., 2013. The control of politicians in normal times and times of crisis: Wealth accumulation by U.S. Congressmen, 1850-1880. Quarterly Journal of Political Science 8, 409-450.

Ramseyer, J.M., and E.B. Rasmussen, 2011. Can the Treasury exempt its own companies from tax? The $\$ 45$ billion GM NOL carryforward. Cato Papers on Public Policy 1, 1-54.

Roberts, B.E., 1990. A dead senator tells no lies: seniority and the distribution of federal benefits. American Journal of Political Science 34, 31-58.

Scheiber, N., 2011. The escape artists: how Obama's team fumbled the recovery. Simon \& Schuster, New York.

Suskind, R., 2011. Confidence men: Wall Street, Washington, and the education of a president. Harper, New York.

Tahoun, A., 2013. The role of stock ownership by US members of Congress on the market for political favors. Unpublished working paper, August.

Useem, M., 1984. The inner circle, Oxford University Press: Oxford.

Veronesi, P. and L. Zingales, 2010. Paulson's gift, Journal of Financial Economics 97(3), 339-368. 

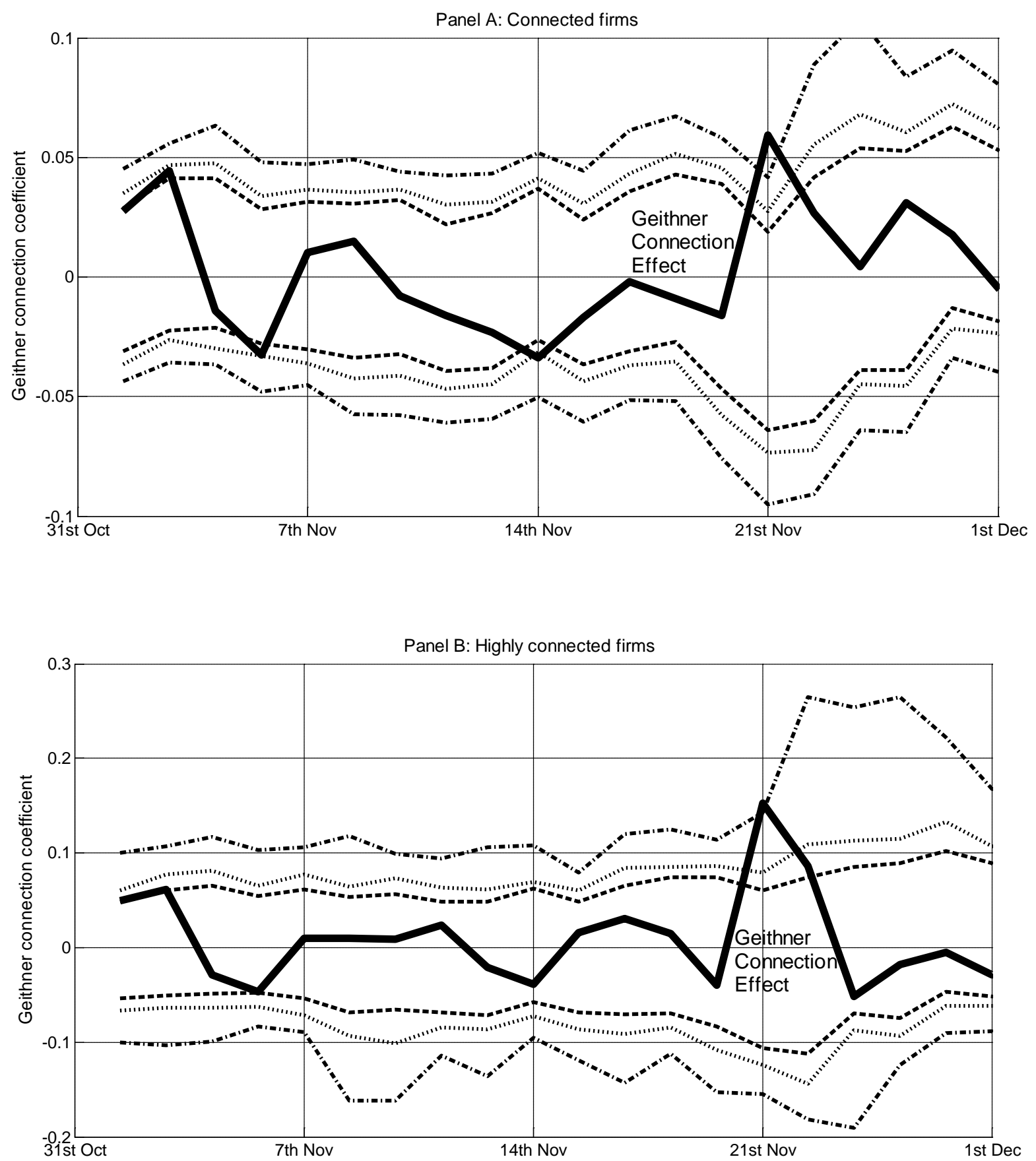

Fig. 1. Time-series plots of the synthetic matching estimate of the coefficient on Geithner connections for cumulative abnormal returns measured over the interval $[x, x+1]$ for each trading day $\mathrm{x}$ in November 2008. Connected firms are represented in Panel A and highly connected firms in Panel B. Confidence intervals at the 1\%,5\%, and 10\% levels are also shown. Citigroup-correlated firms are excluded. November 21, 2008 is the day of the Geithner nomination announcement. 
Table 1

Descriptive Statistics

The table presents descriptive statistics of firm-level data used in subsequent tables. The sample includes firms listed on NYSE or NASDAQ and classified as banks or financial services firms in the Datastream database. The base sample excludes firms with returns highly correlated to Citigroup. Schedule connections denote the number of meetings between the firm's executives and Geithner during 2007-08; personal connections denote the number of shared board memberships between the firm's executives and Geithner; New York connections indicate firms headquartered in New York City. Size (log of total assets), profitability (return on equity), and leverage (total debt to total capital) are from the Worldscope database as of 2008. CDS spreads are from the Markit database and are for five-year contracts, stated in percents. Asterisks denote significance levels of a two-tailed t-test $(* * *=1 \%$, $* *=5 \%, *=10 \%)$.

\begin{tabular}{|c|c|c|c|c|c|c|c|c|c|}
\hline \multicolumn{10}{|l|}{ Panel A: Summary Statistics (Full sample) } \\
\hline & Mean & Min & 25th Pctile & Median & 75th Pctile & Max & St. Dev. & $\mathrm{N}$ & \\
\hline (1) Geithner Connections (Schedule) & 0.21 & 0.00 & 0.00 & 0.00 & 0.00 & 34.00 & 1.74 & 603 & \\
\hline (2) Geithner Connections (Personal) & 0.08 & 0.00 & 0.00 & 0.00 & 0.00 & 9.00 & 0.60 & 603 & \\
\hline (3) Geithner Connection (New York) & 0.07 & 0.00 & 0.00 & 0.00 & 0.00 & 1.00 & 0.26 & 603 & \\
\hline (4) Size & 21.33 & 16.32 & 20.23 & 21.03 & 22.10 & 28.41 & 1.72 & 596 & \\
\hline (5) Profitability & -0.05 & -3.62 & -0.06 & 0.04 & 0.09 & 0.82 & 0.35 & 585 & \\
\hline (6) Leverage & 0.57 & 0.00 & 0.43 & 0.61 & 0.71 & 3.10 & 0.27 & 592 & \\
\hline (7) $\mathrm{CAR}[0]$ & -0.02 & -0.24 & -0.04 & -0.01 & 0.01 & 0.35 & 0.06 & 603 & \\
\hline (8) $\mathrm{CAR}[0,1]$ & -0.02 & -0.46 & -0.07 & -0.02 & 0.03 & 0.48 & 0.11 & 603 & \\
\hline (9) CAR $[0,10]$ & 0.02 & -0.69 & -0.10 & -0.02 & 0.09 & 1.38 & 0.21 & 603 & \\
\hline (10) CDS Spread, Day 1 & 4.65 & 0.23 & 1.16 & 2.33 & 5.32 & 29.29 & 6.15 & 30 & \\
\hline (11) \% Change in CDS Spread[1] & -0.04 & -0.49 & -0.03 & 0.00 & 0.00 & 0.02 & 0.10 & 30 & \\
\hline (12) \% Change in CDS Spread[1,10] & -0.06 & -0.49 & -0.12 & -0.03 & 0.00 & 0.15 & 0.13 & 30 & \\
\hline \multicolumn{10}{|c|}{ Panel B: Geithner Connected vs. Non-connected (Full sample) } \\
\hline & Schedule & Non & Diff. & Personal & Non & Diff. & New York & Non & Diff. \\
\hline (13) Size & 24.40 & 21.20 & $3.20 * * *$ & 25.00 & 21.20 & $3.80 * * *$ & 21.78 & 21.30 & $0.48^{*}$ \\
\hline (14) Profitability & 0.04 & -0.06 & 0.10 & -0.15 & -0.05 & -0.10 & -0.17 & -0.04 & $-0.13^{* *}$ \\
\hline (15) Leverage & 0.73 & 0.56 & $0.17 * * *$ & 0.60 & 0.56 & 0.04 & 0.57 & 0.56 & 0.00 \\
\hline (16) Number of observations in full sample & 25 & 578 & & 21 & 582 & & 45 & 558 & \\
\hline \multicolumn{10}{|c|}{ Panel C: Geithner Connected vs. Non-connected (Base sample) } \\
\hline & Schedule & Non & Diff. & Personal & Non & Diff. & New York & Non & Diff. \\
\hline (17) Size & 23.13 & 20.98 & $2.16^{* * *}$ & 23.17 & 21.00 & $2.17 * * *$ & 20.95 & 21.04 & -0.09 \\
\hline (18) Profitability & 0.06 & -0.07 & 0.13 & -0.42 & -0.06 & $-0.36 * * *$ & -0.20 & -0.05 & $-0.14 * *$ \\
\hline (19) Leverage & 0.71 & 0.56 & $0.15^{* *}$ & 0.52 & 0.57 & -0.05 & 0.54 & 0.57 & -0.03 \\
\hline (20) Number of observations in base sample & 15 & 530 & & 9 & 536 & & 38 & 507 & \\
\hline \multicolumn{10}{|l|}{ Panel D: Correlation Coefficients (Full sample) } \\
\hline & Schedule & Personal & New York & Size & Profitability & Leverage & & & \\
\hline (21) Geithner Connections (Schedule) & 1.00 & & & & & & & & \\
\hline (22) Geithner Connections (Personal) & 0.86 & 1.00 & & & & & & & \\
\hline (23) Geithner Connection (New York) & 0.35 & 0.39 & 1.00 & & & & & & \\
\hline (24) Size & 0.35 & 0.37 & 0.10 & 1.00 & & & & & \\
\hline (25) Profitability & 0.00 & -0.03 & -0.11 & 0.05 & 1.00 & & & & \\
\hline (26) Leverage & 0.04 & 0.06 & -0.15 & 0.28 & -0.16 & 1.00 & & & \\
\hline
\end{tabular}


Table 2

Connections to Geithner and Stock Price Reactions to Treasury Secretary Announcement

The table presents stock returns of financial firms around the announcement of Barack Obama's nomination of Timothy Geithner as Treasury Secretary. Event day 0 is November 21, 2008 from 3pm (when the news leaked) to market closing; the announcement was made on event day 1 . Abnormal returns are calculated using the market model with an estimation window of 250 trading days ending 30 days prior to event day 0 . The base sample excludes firms with returns highly correlated to Citigroup. Schedule connections indicate meetings between the firm's executives and Geithner during 2007-08; personal connections indicate shared board memberships between the firm's executives and Geithner; New York connections indicate firms headquartered in New York City. Asterisks denote significance levels of a two-tailed t-test $(* * *=1 \%, * *=5 \%, *=10 \%)$.

\begin{tabular}{|c|c|c|c|c|c|c|c|c|c|c|}
\hline \multirow[b]{2}{*}{ Event Day } & \multirow[b]{2}{*}{ Date } & \multicolumn{3}{|c|}{ Schedule Connections } & \multicolumn{3}{|c|}{ Personal Connections } & \multicolumn{3}{|c|}{ New York Connections } \\
\hline & & Conn. & Non-Conn. & Difference & Conn. & Non-Conn. & Difference & Conn. & Non-Conn. & Difference \\
\hline 0 & $11 / 21 / 2008$ & 0.086 & 0.042 & $0.043 * *$ & 0.075 & 0.043 & 0.033 & 0.085 & 0.040 & $0.044^{* * *}$ \\
\hline 1 & $11 / 24 / 2008$ & 0.130 & 0.046 & $0.084 * * *$ & 0.143 & 0.047 & $0.096 * * *$ & 0.078 & 0.046 & $0.031 *$ \\
\hline 2 & $11 / 25 / 2008$ & 0.026 & 0.015 & 0.011 & 0.057 & 0.014 & 0.043 & 0.032 & 0.014 & 0.018 \\
\hline 3 & $11 / 26 / 2008$ & 0.112 & 0.041 & $0.071 * * *$ & 0.112 & 0.042 & $0.071 * *$ & 0.087 & 0.040 & $0.048 * * *$ \\
\hline 4 & $11 / 28 / 2008$ & 0.056 & 0.018 & $0.038 *$ & 0.085 & 0.018 & $0.067 * *$ & 0.016 & 0.019 & -0.003 \\
\hline 5 & $12 / 1 / 2008$ & -0.131 & -0.076 & $-0.056 * *$ & -0.144 & -0.076 & $-0.067 * *$ & -0.105 & -0.075 & $-0.030 *$ \\
\hline 6 & $12 / 2 / 2008$ & 0.046 & 0.043 & 0.003 & 0.044 & 0.043 & 0.001 & 0.090 & 0.040 & $0.050 * * *$ \\
\hline 7 & $12 / 3 / 2008$ & 0.034 & 0.018 & 0.016 & 0.043 & 0.018 & 0.024 & 0.031 & 0.018 & 0.013 \\
\hline 8 & $12 / 4 / 2008$ & -0.009 & -0.013 & 0.005 & 0.005 & -0.014 & 0.019 & -0.020 & -0.013 & -0.008 \\
\hline 9 & $12 / 5 / 2008$ & 0.063 & 0.024 & $0.038 * *$ & 0.042 & 0.025 & 0.017 & 0.050 & 0.024 & $0.026 * *$ \\
\hline 10 & $12 / 8 / 2008$ & 0.064 & 0.027 & 0.037 & 0.072 & 0.028 & $0.045 * *$ & 0.050 & 0.027 & 0.023 \\
\hline $0-10$ & (Cumulative) & 0.551 & 0.180 & $0.371 * * *$ & 0.645 & 0.183 & $0.463 * * *$ & 0.468 & 0.169 & $0.299 * * *$ \\
\hline \multicolumn{11}{|c|}{ Panel B: Cumulative abnormal returns, Base sample } \\
\hline \multirow[b]{2}{*}{ Event Day } & \multirow[b]{2}{*}{ Date } & \multicolumn{3}{|c|}{ Schedule Connections } & \multicolumn{3}{|c|}{ Personal Connections } & \multicolumn{3}{|c|}{ New York Connections } \\
\hline & & Conn. & Non-Conn. & Difference & Conn. & Non-Conn. & Difference & Conn. & Non-Conn. & Difference \\
\hline 0 & $11 / 21 / 2008$ & -0.013 & -0.015 & 0.001 & -0.034 & -0.014 & -0.020 & -0.005 & -0.015 & 0.010 \\
\hline 1 & $11 / 24 / 2008$ & 0.024 & -0.022 & 0.046 & 0.005 & -0.021 & 0.026 & -0.011 & -0.021 & 0.010 \\
\hline 2 & $11 / 25 / 2008$ & 0.039 & -0.013 & 0.052 & 0.052 & -0.012 & 0.064 & 0.012 & -0.013 & 0.025 \\
\hline 3 & $11 / 26 / 2008$ & 0.099 & -0.001 & $0.101 * *$ & 0.107 & 0.000 & $0.108 *$ & 0.053 & -0.002 & $0.055 *$ \\
\hline 4 & $11 / 28 / 2008$ & 0.141 & 0.009 & $0.132 * * *$ & 0.177 & 0.009 & $0.167 * * *$ & 0.056 & 0.009 & 0.048 \\
\hline 5 & $12 / 1 / 2008$ & 0.136 & 0.006 & $0.129 * * *$ & 0.175 & 0.007 & $0.168 * * *$ & 0.067 & 0.006 & $0.061 * *$ \\
\hline 6 & $12 / 2 / 2008$ & 0.124 & 0.017 & $0.107 * *$ & 0.156 & 0.017 & $0.138 * *$ & 0.105 & 0.013 & $0.092 * * *$ \\
\hline 7 & $12 / 3 / 2008$ & 0.120 & 0.013 & $0.107^{* *}$ & 0.156 & 0.014 & $0.142 * *$ & 0.101 & 0.010 & $0.091 * * *$ \\
\hline 8 & $12 / 4 / 2008$ & 0.152 & 0.024 & $0.129 * *$ & 0.208 & 0.024 & $0.184 * * *$ & 0.118 & 0.021 & $0.098 * * *$ \\
\hline 9 & $12 / 5 / 2008$ & 0.162 & 0.018 & $0.144 * * *$ & 0.192 & 0.019 & $0.172 * * *$ & 0.121 & 0.015 & $0.106 * * *$ \\
\hline 10 & $12 / 8 / 2008$ & 0.171 & 0.014 & $0.157 * * *$ & 0.173 & 0.015 & $0.158 * *$ & 0.120 & 0.010 & $0.110 * * *$ \\
\hline
\end{tabular}


Table 3

Connections to Geithner and Reactions to Treasury Secretary Announcement, OLS Regression Results

The table reports coefficient estimates of OLS regressions of cumulative abnormal returns (CARs) surrounding the announcement of Geithner as Treasury Secretary on measures of connections to Geithner. Event day 0 is November 21, 2008 from 3pm (when the news leaked) to market closing; the announcement was made on event day 1. The CAR is measured as day 0 only, from day 0 to day 1, or from day 0 to day 10, as indicated. Abnormal returns are calculated using the market model with an estimation window of 250 trading days ending 30 days prior to event day 0 . The base sample excludes firms with returns highly correlated to Citigroup. Schedule connections denote the number of meetings between the firm's executives and Geithner during 2007-08; personal connections denote the number of shared board memberships between the firm's executives and Geithner; New York connections indicate firms headquartered in New York City. Control variables include cubics in size (log of total assets), profitability (return on equity), and leverage (total debt to total capital) as of 2008. Robust standard errors, adjusted for pre-event correlations between firms, are below coefficients in parentheses. Asterisks denote significance levels $(* * *=1 \%, * *=5 \%$, *=10\%).

\begin{tabular}{|c|c|c|c|c|c|c|c|c|c|c|c|c|}
\hline \multirow[b]{4}{*}{ Geithner Connections } & \multirow{2}{*}{\multicolumn{3}{|c|}{$\begin{array}{c}(1) \\
\begin{array}{c}\text { Dependent variable is CAR [0] } \\
\text { (Full sample) }\end{array}\end{array}$}} & $(4)$ & (5) & $(6)$ & $(7)$ & & $(8)$ & & $(9)$ & \\
\hline & & & & \multicolumn{3}{|c|}{$\begin{array}{c}\text { Dependent variable is CAR [0,1] } \\
\text { (Base sample) }\end{array}$} & \multicolumn{6}{|c|}{$\begin{array}{c}\text { Dependent variable is CAR }[0,10] \\
\text { (Base sample) }\end{array}$} \\
\hline & Schedule & Personal & New York & \multirow{2}{*}{$\begin{array}{l}\text { Schedule } \\
0.011^{* * *} \\
(0.003)\end{array}$} & \multirow{2}{*}{$\begin{array}{l}\text { Personal } \\
0.050^{* * *} \\
(0.010)\end{array}$} & \multirow{2}{*}{$\begin{array}{c}\text { New York } \\
0.005 \\
(0.011)\end{array}$} & \multicolumn{2}{|c|}{ Schedule } & \multicolumn{2}{|c|}{ Personal } & \multicolumn{2}{|c|}{ New York } \\
\hline & $\begin{array}{l}0.0033 \text { *** } \\
(0.0009)\end{array}$ & $\begin{array}{l}0.0073 * * \\
(0.0031)\end{array}$ & $\begin{array}{l}0.0132 \\
(0.0072)\end{array}$ & & & & $\begin{array}{c}0.009 \\
(0.007)\end{array}$ & & $\begin{array}{c}0.070 \\
(0.023)\end{array}$ & *** & $\begin{array}{c}0.108 \\
(0.023)\end{array}$ & $* * *$ \\
\hline Size & $\begin{array}{l}-0.146 \\
(0.204)\end{array}$ & $\begin{array}{l}-0.109 \\
(0.208)\end{array}$ & $\begin{array}{l}-0.004 \\
(0.203)\end{array}$ & $\begin{array}{c}0.789 \\
(0.668)\end{array}$ & $\begin{array}{c}0.882 \\
(0.685)\end{array}$ & $\begin{array}{c}0.963 \\
(0.687)\end{array}$ & $\begin{array}{c}2.640 \\
(1.636)\end{array}$ & & $\begin{array}{c}2.663 \\
(1.664)\end{array}$ & & $\begin{array}{c}2.387 \\
(1.657)\end{array}$ & \\
\hline $\operatorname{Size}^{2}$ & $\begin{array}{c}0.007 \\
(0.009)\end{array}$ & $\begin{array}{c}0.005 \\
(0.010)\end{array}$ & $\begin{array}{c}0.000 \\
(0.009)\end{array}$ & $\begin{array}{l}-0.039 \\
(0.032)\end{array}$ & $\begin{array}{l}-0.044 \\
(0.033)\end{array}$ & $\begin{array}{l}-0.048 \\
(0.033)\end{array}$ & $\begin{array}{l}-0.129 \\
(0.078)\end{array}$ & & $\begin{array}{l}-0.131 \\
(0.080)\end{array}$ & & $\begin{array}{l}-0.117 \\
(0.079)\end{array}$ & \\
\hline $\operatorname{Size}^{3}$ & $\begin{array}{c}0.000 \\
(0.000)\end{array}$ & $\begin{array}{c}0.000 \\
(0.000)\end{array}$ & $\begin{array}{c}0.000 \\
(0.000)\end{array}$ & $\begin{array}{c}0.001 \\
(0.001)\end{array}$ & $\begin{array}{c}0.001 \\
(0.001)\end{array}$ & $\begin{array}{c}0.001 \\
(0.001)\end{array}$ & $\begin{array}{c}0.002 \\
(0.001)\end{array}$ & $*$ & $\begin{array}{c}0.002 \\
(0.001)\end{array}$ & $*$ & $\begin{array}{c}0.002 \\
(0.001)\end{array}$ & \\
\hline Profitability & $\begin{array}{l}0.039 * * * \\
(0.014)\end{array}$ & $\begin{array}{l}0.039 * * * \\
(0.014)\end{array}$ & $\begin{array}{l}0.0388^{* * *} \\
(0.014)\end{array}$ & $\begin{array}{c}0.029 \\
(0.024)\end{array}$ & $\begin{array}{c}0.033 \\
(0.024)\end{array}$ & $\begin{array}{c}0.029 \\
(0.024)\end{array}$ & $\begin{array}{l}-0.156 \\
(0.064)\end{array}$ & & $\begin{array}{l}-0.150 \\
(0.065)\end{array}$ & ** & $\begin{array}{l}-0.164 \\
(0.064)\end{array}$ & $* *$ \\
\hline Profitability $^{2}$ & $\begin{array}{c}0.011 \\
(0.020)\end{array}$ & $\begin{array}{c}0.010 \\
(0.020)\end{array}$ & $\begin{array}{c}0.008 \\
(0.020)\end{array}$ & $\begin{array}{c}0.005 \\
(0.035)\end{array}$ & $\begin{array}{c}0.003 \\
(0.035)\end{array}$ & $\begin{array}{c}0.004 \\
(0.035)\end{array}$ & $\begin{array}{l}-0.175 \\
(0.091)\end{array}$ & & $\begin{array}{l}-0.178 \\
(0.091)\end{array}$ & * & $\begin{array}{l}-0.205 \\
(0.090)\end{array}$ & ** \\
\hline Profitability $^{3}$ & $\begin{array}{l}-0.001 \\
(0.006)\end{array}$ & $\begin{array}{l}-0.001 \\
(0.006)\end{array}$ & $\begin{array}{l}-0.001 \\
(0.006)\end{array}$ & $\begin{array}{c}0.006 \\
(0.010)\end{array}$ & $\begin{array}{c}0.005 \\
(0.010)\end{array}$ & $\begin{array}{c}0.005 \\
(0.010)\end{array}$ & $\begin{array}{l}-0.034 \\
(0.023)\end{array}$ & & $\begin{array}{l}-0.035 \\
(0.023)\end{array}$ & & $\begin{array}{l}-0.040 \\
(0.023)\end{array}$ & * \\
\hline Leverage & $\begin{array}{l}-0.012 \\
(0.061)\end{array}$ & $\begin{array}{l}-0.013 \\
(0.062)\end{array}$ & $\begin{array}{l}-0.011 \\
(0.063)\end{array}$ & $\begin{array}{l}-0.075 \\
(0.079)\end{array}$ & $\begin{array}{l}-0.063 \\
(0.079)\end{array}$ & $\begin{array}{l}-0.096 \\
(0.082)\end{array}$ & $\begin{array}{c}0.567 \\
(0.146)\end{array}$ & $* * *$ & $\begin{array}{c}0.599 \\
(0.147)\end{array}$ & $* * *$ & $\begin{array}{c}0.670 \\
(0.153)\end{array}$ & $* * *$ \\
\hline Leverage $^{2}$ & $\begin{array}{c}0.087 \\
(0.181)\end{array}$ & $\begin{array}{c}0.088 \\
(0.181)\end{array}$ & $\begin{array}{c}0.088 \\
(0.182)\end{array}$ & $\begin{array}{c}0.091 \\
(0.226)\end{array}$ & $\begin{array}{c}0.078 \\
(0.226)\end{array}$ & $\begin{array}{c}0.128 \\
(0.229)\end{array}$ & $\begin{array}{l}-1.872 \\
(0.463)\end{array}$ & $* * *$ & $\begin{array}{l}-1.916 \\
(0.464)\end{array}$ & $* * *$ & $\begin{array}{l}-0.203 \\
(0.476)\end{array}$ & $* * *$ \\
\hline Leverage $^{3}$ & $\begin{array}{l}-0.095 \\
(0.142)\end{array}$ & $\begin{array}{l}-0.096 \\
(0.142)\end{array}$ & $\begin{array}{l}-0.096 \\
(0.142)\end{array}$ & $\begin{array}{l}-0.008 \\
(0.177)\end{array}$ & $\begin{array}{l}-0.007 \\
(0.177)\end{array}$ & $\begin{array}{l}-0.033 \\
(0.179)\end{array}$ & $\begin{array}{c}1.449 \\
(0.388)\end{array}$ & $* * *$ & $\begin{array}{c}1.467 \\
(0.387)\end{array}$ & $* * *$ & $\begin{array}{c}1.539 \\
(0.395)\end{array}$ & \\
\hline Number of firms & 583 & 583 & 583 & 525 & 525 & 525 & 525 & & 525 & & 525 & \\
\hline R-squared & 0.038 & 0.036 & 0.036 & 0.043 & 0.049 & 0.038 & 0.065 & & 0.070 & & 0.078 & \\
\hline
\end{tabular}


Table 4

Connections to Geithner and Reactions to Treasury Secretary Announcement, OLS Robustness Checks

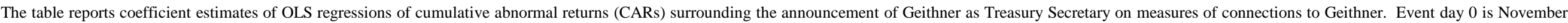

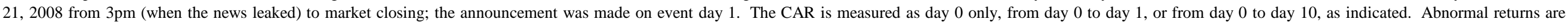

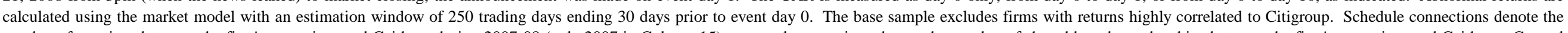

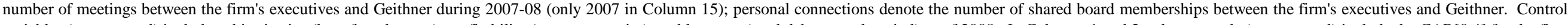

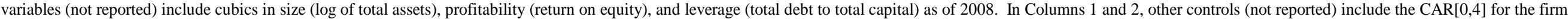

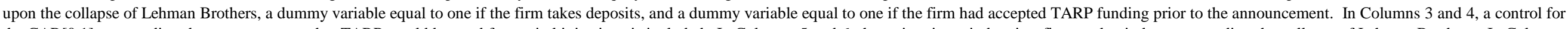

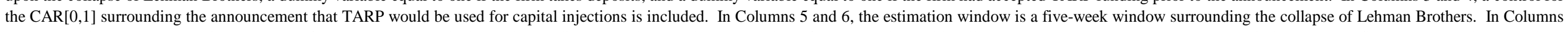

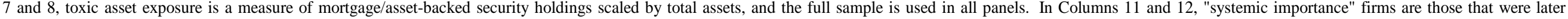

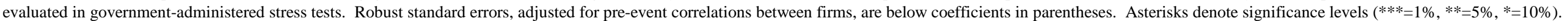

\begin{tabular}{|c|c|c|c|c|c|c|c|c|c|c|c|c|c|c|c|}
\hline & $(1)$ & $(2)$ & (3) & $(4)$ & (5) & $(6)$ & $(7)$ & $(8)$ & (9) & $(10)$ & $(11)$ & $(12)$ & (13) & (14) & (15) \\
\hline & $\begin{array}{r}\text { Control } f \\
\text { vulner } \\
\end{array}$ & $\begin{array}{l}\text { or crisis } \\
\text { ability }\end{array}$ & $\begin{array}{l}\text { Control for } r \\
\text { TARP capita }\end{array}$ & $\begin{array}{l}\text { response to } \\
\text { l injections }\end{array}$ & $\begin{array}{c}\text { Lehman } \\
\text { estimati } \\
\end{array}$ & $\begin{array}{l}\text { collapse } \\
\text { on beta }\end{array}$ & $\begin{array}{r}\text { Control for } \\
\text { expos }\end{array}$ & $\begin{array}{l}\text { toxic asset } \\
\text { sure }\end{array}$ & Top size d & lecile only & $\begin{array}{l}\text { Exclude " } \\
\text { importan }\end{array}$ & 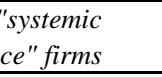 & $\begin{array}{r}\text { Exclude ext } \\
(1 \% / 9\end{array}$ & $\begin{array}{l}\text { reme CARs } \\
99 \%)\end{array}$ & $\begin{array}{c}2007 \text { appts. } \\
\text { only }\end{array}$ \\
\hline & Schedule & Personal & Schedule & Personal & Schedule & Personal & Schedule & Personal & Schedule & Personal & Schedule & Personal & Schedule & Personal & Schedule \\
\hline \multicolumn{16}{|c|}{ Panel A: Dependent variable is CAR [0] (Full sample) } \\
\hline Geithner Connections & $\begin{array}{l}0.0034^{* * *} \\
(0.0010)\end{array}$ & $\begin{array}{l}0.0079^{* * *} \\
(0.0029)\end{array}$ & $\begin{array}{l}0.00322^{* * *} \\
(0.0009)\end{array}$ & $\begin{array}{l}0.00755^{* *} \\
(0.0031)\end{array}$ & $\begin{array}{l}0.0046 * * * \\
(0.0009)\end{array}$ & $\begin{array}{l}0.0144 * * * \\
(0.0031)\end{array}$ & $\begin{array}{l}0.0030 * * * \\
(0.0010)\end{array}$ & $\begin{array}{l}0.0108 * * * \\
(0.0037)\end{array}$ & $\begin{array}{l}0.0029 \text { *** } \\
(0.0009)\end{array}$ & $\begin{array}{l}0.0058 * \\
(0.0033)\end{array}$ & $\begin{array}{l}0.0037 \quad * \\
(0.0022)\end{array}$ & $\begin{array}{c}0.0052 \\
(0.0065)\end{array}$ & $\begin{array}{l}0.0032 * * * \\
(0.0009)\end{array}$ & $\begin{array}{c}0.0070 * * \\
(0.0031)\end{array}$ & $\begin{array}{l}0.00433^{* * *} \\
(0.0013)\end{array}$ \\
\hline Number of firms & 576 & 576 & 579 & 579 & 583 & 583 & 196 & 196 & 58 & 58 & 566 & 566 & 571 & 571 & 583 \\
\hline R-squared & 0.040 & 0.037 & 0.049 & 0.047 & 0.063 & 0.064 & 0.063 & 0.061 & 0.358 & 0.303 & 0.036 & 0.035 & 0.043 & 0.039 & 0.037 \\
\hline \multicolumn{16}{|c|}{ Panel B: Dependent variable is CAR [0,1] (Base sample) } \\
\hline Geithner Connections & $\begin{array}{l}0.0111^{* * *} \\
(0.003)\end{array}$ & $\begin{array}{l}0.0511^{* * *} \\
(0.010)\end{array}$ & $\begin{array}{l}0.0111^{* * *} \\
(0.003)\end{array}$ & $\begin{array}{l}l_{0.048}^{* * *} \\
(0.010)\end{array}$ & $\begin{array}{l}0.015^{* * *} \\
(0.003)\end{array}$ & $\begin{array}{l}0.065^{* * *} \\
(0.010)\end{array}$ & $\begin{array}{l}0.0144^{* * *} \\
(0.001)\end{array}$ & $\begin{array}{l}0.051 * * * \\
(0.006)\end{array}$ & $\begin{array}{l}-0.002 \\
(0.003)\end{array}$ & $\begin{array}{l}0.039^{* * *} \\
(0.013)\end{array}$ & $\begin{array}{l}0.0122^{* * *} \\
(0.003)\end{array}$ & $\begin{array}{l}0.0511^{* * *} \\
(0.010)\end{array}$ & $\begin{array}{l}0.0099^{* * *} \\
(0.003)\end{array}$ & $\begin{array}{l}0.048^{* * *} \\
(0.011)\end{array}$ & $\begin{array}{l}0.030 \quad * * * \\
(0.005)\end{array}$ \\
\hline Number of firms & 518 & 518 & 521 & 521 & 525 & 525 & 196 & 196 & 52 & 52 & 523 & 523 & 517 & 517 & 525 \\
\hline R-squared & 0.042 & 0.050 & 0.039 & 0.045 & 0.057 & 0.065 & 0.232 & 0.217 & 0.217 & 0.250 & 0.040 & 0.048 & 0.056 & 0.065 & 0.048 \\
\hline \multicolumn{16}{|c|}{ Panel C: Dependent variable is CAR $[0,10]$ (Base sample) } \\
\hline Geithner Connections & $\begin{array}{c}0.004 \\
(0.006)\end{array}$ & $\begin{array}{c}0.0455^{* *} \\
(0.021)\end{array}$ & $\begin{array}{c}0.008 \\
(0.006)\end{array}$ & 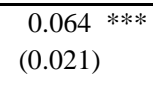 & $\begin{array}{l}{ }_{0.023}^{* * *} \\
(0.007)\end{array}$ & $\begin{array}{l}0.120^{* * *} \\
(0.023)^{*}\end{array}$ & $\begin{array}{l}0.020^{* * *} \\
(0.004)\end{array}$ & $\begin{array}{l}0.076^{* * *} \\
(0.014)\end{array}$ & $\begin{array}{c}0.002 \\
(0.008)\end{array}$ & $\begin{array}{l}0.140^{* * *} \\
(0.032)\end{array}$ & $\begin{array}{c}c^{0.018}{ }^{* *} \\
(0.007)\end{array}$ & $\begin{array}{l}{ }_{0.065}^{* * *} \\
(0.022)\end{array}$ & $\begin{array}{c}0.010 \\
(0.007)\end{array}$ & $\begin{array}{l}0.072 \text { *** } \\
(0.023)\end{array}$ & $\begin{array}{l}-0.003 \\
(0.010)\end{array}$ \\
\hline Number of firms & 518 & 518 & 521 & 521 & 525 & 525 & 196 & 196 & 52 & 52 & 523 & 523 & 516 & 516 & 525 \\
\hline R-squared & 0.120 & 0.122 & 0.074 & 0.078 & 0.073 & 0.080 & 0.246 & 0.240 & 0.117 & 0.229 & 0.071 & 0.073 & 0.067 & 0.074 & 0.064 \\
\hline
\end{tabular}


Table 5

Connections to Geithner and Reactions to Treasury Secretary Announcement, Synthetic Matching Estimation

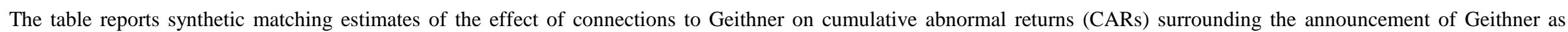

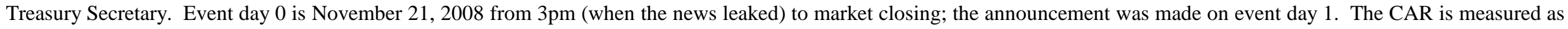

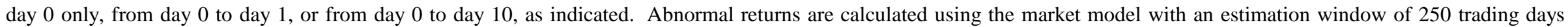

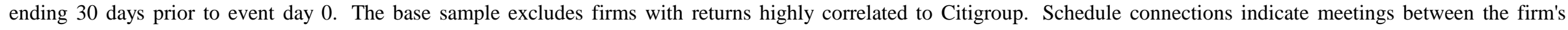

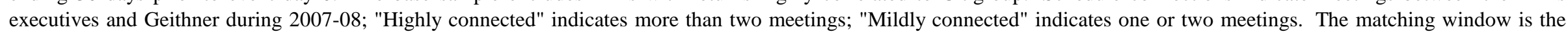

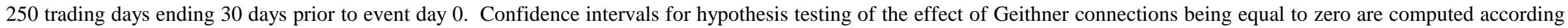

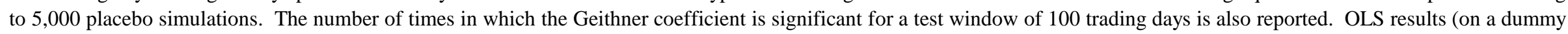

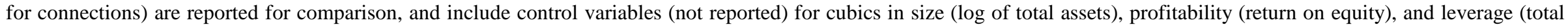
debt to total capital) as of 2008 . Asterisks denote significance levels (***=1\%, $* *=5 \%, *=10 \%)$.

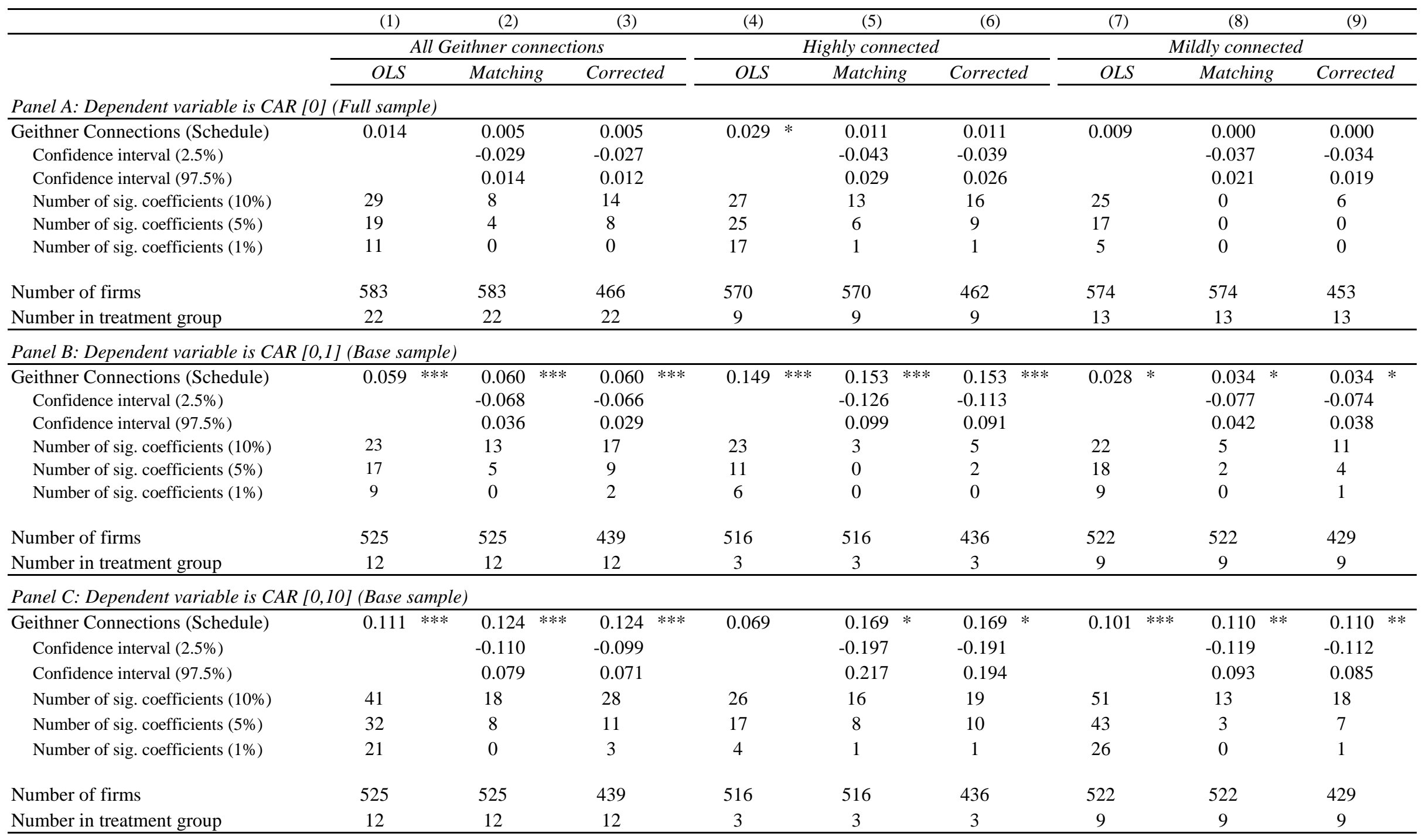


Table 6

Connections to Geithner and Reactions to Treasury Secretary Announcement, Synthetic Matching Robustness Checks

The table reports synthetic matching estimates of the effect of connections to Geithner on cumulative abnormal returns (CARs) surrounding the announcement of Geithner as Treasury Secretary. Event day 0 is November 21, 2008 from 3pm (when the news leaked) to market closing; the announcement was made on event day 1. The CAR is measured from day 0 to day 1 . Abnormal returns are calculated using the market model with an estimation window of 250 trading days ending 30 days prior to event day 0 (a five-week window surrounding the collapse of Lehman Brothers in Panel A). The base sample (used throughout the table) excludes firms with returns highly correlated to Citigroup. Schedule connections denote the number of meetings between the firm's executives and Geithner during 2007-08 (only 2007 in Panel D); personal connections denote the number of shared board memberships between the firm's executives and Geithner; New York connections indicate firms headquartered in New York City. "Highly connected" indicates more than one connection (more than two in Panel A); "Mildly connected" indicates one connection (one or two in Panel A). The matching window is the 250 trading days ending 30 days prior to event day 0 . Confidence intervals for hypothesis testing of the effect of Geithner connections being equal to zero are computed according to 5,000 placebo simulations. OLS results (on a dummy for connections) are reported for comparison, and include control variables (not reported) for cubics in size (log of total assets), profitability (return on equity), and leverage (total debt to total capital) as of 2008. Asterisks denote significance levels ( $* * *=1 \%, * *=5 \%, *=10 \%$ ).

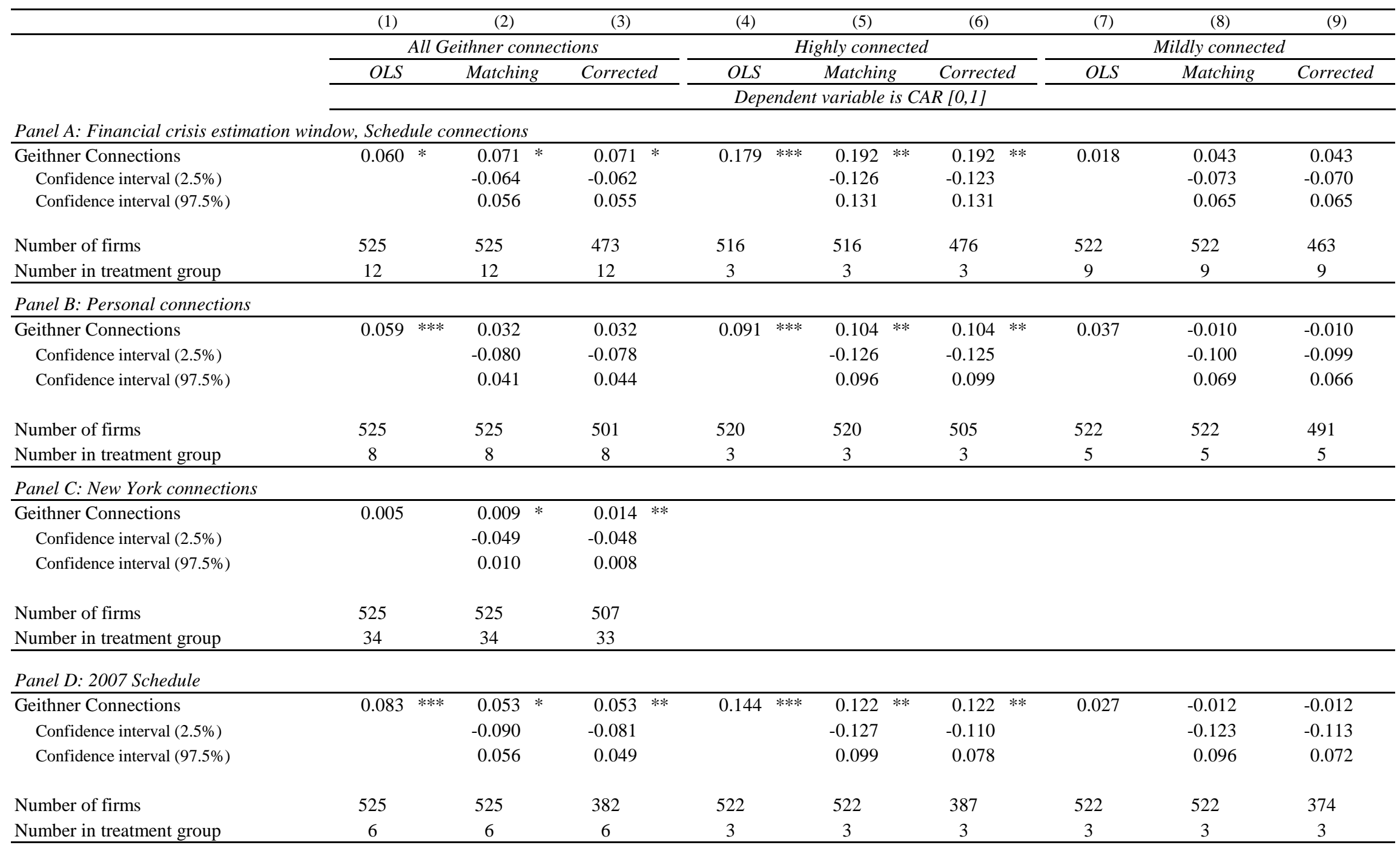


Table 7

Connections to Geithner and Returns Prior to Treasury Secretary Announcement

The table reports synthetic matching estimates of the effect of connections to Geithner on cumulative abnormal returns (CARs) surrounding the announcement of Geithner as Treasury Secretary. Event day 0 is November 21, 2008 from 3pm (when the news leaked) to market closing; the announcement was made on event day 1 . The CAR is measured from event day -1 to event day 0 , day -5 to day 0 , or day -10 to day 0 as indicated. Abnormal returns are calculated using the market model with an estimation window of 250 trading days ending 30 days prior to event day 0 . The base sample (used throughout the table) excludes firms with returns highly correlated to Citigroup. Schedule connections denote the number of meetings between the firm's executives and Geithner during 2007-08; personal connections denote the number of shared board memberships between the firm's executives and Geithner; New York connections indicate firms headquartered in New York City. "Highly connected" indicates more than two meetings, "Mildly connected" indicates one or two meetings. Confidence intervals for hypothesis testing of the effect of Geithner connections being equal to zero are computed according to 5,000 placebo simulations. Asterisks denote significance levels $(* * *=1 \%, * *=5 \%, *=10 \%)$.

\begin{tabular}{|c|c|c|c|c|c|}
\hline & $(1)$ & $(2)$ & (3) & $(4)$ & (5) \\
\hline & All Conn. & Highly Conn. & Mildly Conn. & \multicolumn{2}{|c|}{ All Conn. } \\
\hline & & Schedule & & Personal & New York \\
\hline \multicolumn{6}{|c|}{ Panel A: Dependent variable is CAR $[-1,0]$} \\
\hline Geithner Connections & -0.013 & -0.040 & -0.005 & -0.016 & -0.017 \\
\hline Confidence interval (2.5\%) & -0.049 & -0.119 & -0.060 & -0.061 & -0.026 \\
\hline Confidence interval (97.5\%) & 0.044 & 0.092 & 0.052 & 0.056 & 0.027 \\
\hline Number of firms & 525 & 516 & 522 & 525 & 525 \\
\hline Number in treatment group & 12 & 3 & 9 & 8 & 34 \\
\hline \multicolumn{6}{|c|}{ Panel B: Dependent variable is CAR[-5,0] } \\
\hline Geithner Connections & -0.053 & -0.047 & -0.055 & -0.040 & -0.0143 \\
\hline Confidence interval (2.5\%) & -0.060 & -0.159 & -0.074 & -0.082 & -0.0272 \\
\hline Confidence interval (97.5\%) & 0.072 & 0.142 & 0.086 & 0.088 & 0.04866 \\
\hline Number of firms & 525 & 516 & 522 & 525 & 525 \\
\hline Number in treatment group & 12 & 3 & 9 & 8 & 34 \\
\hline \multicolumn{6}{|c|}{ Panel C: Dependent variable is CAR[-10,0] } \\
\hline Geithner Connections & -0.064 & -0.021 & -0.077 & -0.090 & $-0.040 *$ \\
\hline Confidence interval (2.5\%) & -0.087 & -0.216 & -0.102 & -0.119 & -0.041 \\
\hline Confidence interval (97.5\%) & 0.087 & 0.166 & 0.099 & 0.107 & 0.055 \\
\hline Number of firms & 525 & 516 & 522 & 525 & 525 \\
\hline Number in treatment group & 12 & 3 & 9 & 8 & 34 \\
\hline
\end{tabular}


Table 8

Connections to Geithner and Reactions to Treasury Secretary Announcement, CDS Spreads

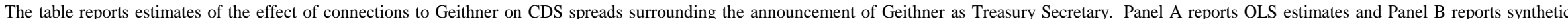

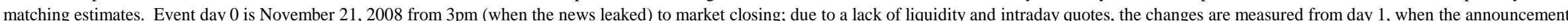

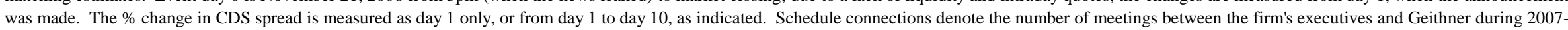

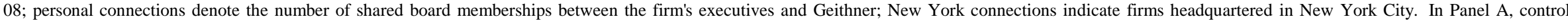

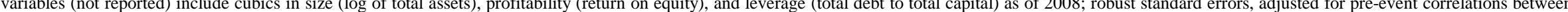

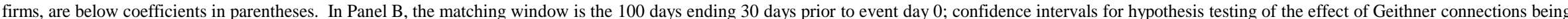
equal to zero are computed according to 5,000 placebo simulations. Asterisks denote significance levels $(* * *=1 \%, * *=5 \%, *=10 \%)$.

\begin{tabular}{|c|c|c|c|c|c|c|c|c|c|c|c|c|}
\hline & $(1)$ & $(2)$ & (3) & $(4)$ & $(5)$ & $(6)$ & $(7)$ & $(8)$ & $(9)$ & $(10)$ & $(11)$ & $(12)$ \\
\hline \multicolumn{13}{|l|}{ Panel A: OLS estimates } \\
\hline & \multicolumn{6}{|c|}{ Dependent variable is \% change in CDS spread [1] } & \multicolumn{6}{|c|}{ Dependent variable is \% change in CDS spread $[1,10]$} \\
\hline \multirow[b]{3}{*}{ Geithner Connections } & \multicolumn{3}{|c|}{ Citigroup included } & \multicolumn{3}{|c|}{ Citigroup excluded } & \multicolumn{3}{|c|}{ Citigroup included } & \multicolumn{3}{|c|}{ Citigroup excluded } \\
\hline & Schedule & Personal & New York & Schedule & Personal & New York & Schedule & Personal & New York & Schedule & Personal & New York \\
\hline & $\begin{array}{l}-0.014^{* * *} \\
(0.002)\end{array}$ & $\begin{array}{l}-0.035^{* * *} \\
(0.007)\end{array}$ & $\begin{array}{l}-0.1133^{* *} \\
(0.044)\end{array}$ & $\begin{array}{l}-0.010 \\
(0.005)\end{array}$ & $\begin{array}{l}-0.0199^{* *} \\
(0.010)\end{array}$ & $\begin{array}{l}-0.072 \\
(0.049)\end{array}$ & $\begin{array}{l}-0.011 \\
(0.007)\end{array}$ & $\begin{array}{l}-0.030 \\
(0.028)\end{array}$ & $\begin{array}{l}-0.202 \\
(0.150)\end{array}$ & $\begin{array}{l}-0.010 \\
(0.022)\end{array}$ & $\begin{array}{l}-0.019 \\
(0.038)\end{array}$ & $\begin{array}{l}-0.176 \\
(0.164)\end{array}$ \\
\hline Number of firms & 27 & 27 & 27 & 26 & 26 & 26 & 27 & 27 & 27 & 26 & 26 & 26 \\
\hline R-squared & 0.941 & 0.795 & 0.615 & 0.772 & 0.834 & 0.748 & 0.671 & 0.639 & 0.726 & 0.479 & 0.493 & 0.674 \\
\hline
\end{tabular}

Panel B: Synthetic matching estimates

Dependent variable is \% change in CDS spread [1]

\begin{tabular}{lll}
\hline \multicolumn{3}{c}{ Citigroup included } \\
\hline Schedule & Personal & New York \\
\hline$-0.087^{* * *}$ & $-0.047^{* * *}$ & $-0.119^{* * *}$ \\
$-0.003^{*}$ & $0.000^{*}$ & -0.005
\end{tabular}

Geithner Connections

Confidence interval (2.5\%)

Confidence interval (97.5\%)

0.000

0.001

$-0.005$

-

\section{Citigroup excluded}

Schedule Personal New York

$\begin{array}{lll}-0.026^{* * *} & -0.024^{* * *} & -0.044^{* * *}\end{array}$

$\begin{array}{lll}-0.004 & 0.000 & -0.006\end{array}$

$\begin{array}{lll}0.005 & 0.001 & 0.011\end{array}$

\begin{tabular}{ccc}
\multicolumn{3}{c}{ Dependent variable is \% chen } \\
\hline \multicolumn{3}{c}{ Citigroup included } \\
\hline Schedule & Personal & New York \\
\hline-0.042 & $-0.092^{* * *}$ & $-0.203^{* * *}$ \\
-0.067 & -0.019 & -0.068 \\
0.040 & 0.000 & 0.055 \\
& & \\
27 & 27 & 27
\end{tabular}

\begin{tabular}{ccc}
\multicolumn{3}{c}{ Citigroup excluded } \\
\hline Schedule & Personal & New York \\
\hline 0.018 & $-0.071^{* * *}$ & $-0.150^{* * *}$ \\
-0.072 & -0.034 & -0.072 \\
0.054 & 0.006 & 0.072 \\
& & \\
26 & 26 & 26
\end{tabular}

Number of firms

27

27

26

10

5

7

11

6

10 
Table 9

Connections to Other Treasury Secretary Candidates and Reactions to Treasury Secretary Announcement

The table reports coefficient estimates of OLS regressions of cumulative abnormal stock returns (CARs) and percent changes in CDS spreads surrounding the announcement of Geithner as Treasury Secretary on measures of connections to Treasury Secretary candidates. Event day 0 is November 21, 2008 from 3pm (when the news leaked) to market closing; the announcement was made on event day 1. In Columns 1 to 3, the CAR is measured from day 0 to day 1 , and in Columns 4 to 6 , the percent change in CDS spreads is measured for day 1 . Abnormal stock returns are calculated using the market model with an estimation window of 250 trading days ending 30 days prior to event day 0 . Estimates for the full sample (excluding Citigroup in CAR results) are reported. Connections denote the number of shared board memberships between the firm's executives and the candidate. Control variables (not reported) include cubics in size (log of total assets), profitability (return on equity), and leverage (total debt to total capital) as of 2008. Robust standard errors, adjusted for pre-event correlations between firms, are below coefficients in parentheses. Asterisks denote significance levels (***=1\%, **=5\%, $*=10 \%)$.

\begin{tabular}{|c|c|c|c|c|c|c|}
\hline & (1) & (2) & (3) & (4) & (5) & (6) \\
\hline \multirow[b]{2}{*}{ Geithner Connections } & \multicolumn{3}{|c|}{ Dependent variable is $C A R[0,1]$} & \multicolumn{3}{|c|}{ Dep. variable is \% change in CDS spread [1] } \\
\hline & $\begin{array}{l}0.020{ }^{* * *} \\
(0.005)\end{array}$ & $\begin{array}{l}0.023 \text { ** } \\
(0.010)\end{array}$ & $\begin{array}{c}0.017 * \\
(0.010)\end{array}$ & $\begin{array}{l}-0.035 * * * \\
(0.007)\end{array}$ & $\begin{array}{l}-0.063 * * * \\
(0.015)\end{array}$ & $\begin{array}{l}-0.070 * * * \\
(0.014)\end{array}$ \\
\hline Summers Connections & & $\begin{array}{c}0.011 \\
(0.016)\end{array}$ & & & $\begin{array}{l}-0.024 \\
(0.034)\end{array}$ & \\
\hline Corzine Connections & & $\begin{array}{c}0.020 \\
(0.015)\end{array}$ & & & $\begin{array}{l}0.089 * * \\
(0.033)\end{array}$ & \\
\hline Volcker Connections & & $\begin{array}{l}-0.018 \\
(0.019)\end{array}$ & & & $\begin{array}{l}0.052 * * \\
(0.021)\end{array}$ & \\
\hline Bair Connections & & $\begin{array}{l}-0.022 \\
(0.038)\end{array}$ & & & & \\
\hline Other Candidates Combined & & & $\begin{array}{c}0.002 \\
(0.007)\end{array}$ & & & $\begin{array}{l}0.028 * * * \\
(0.010)\end{array}$ \\
\hline Number of firms & 582 & 582 & 582 & 27 & 27 & 27 \\
\hline R-squared & 0.048 & 0.049 & 0.048 & 0.795 & 0.941 & 0.880 \\
\hline
\end{tabular}


ONLINE APPENDIX: ADDITIONAL TABLES (NOT FOR PUBLICATION) 
Appendix Table A1

Comparison of Geithner-Connected Firms to Non-Connected Firms

The table compares firms with identifiable connections to Geithner to those with no connections. Schedule connections (Panel A) denote the number of meetings between the firm's executives and Geithner during 2007-08; personal connections (Panel B) denote the number of shared board memberships between the firm's executives and Geithner. "Base Sample" indicates whether the firm is included in the base sample (by virtue of not being highly correlated to Citigroup). CAR [0,10] is the cumulative abnormal return for the firm surrounding the announcement of Geithner as Treasury Secretary. Total assets are for the year 2008 from Worldscope.

Panel A: Schedule Connections

\begin{tabular}{|c|c|c|c|c|c|c|c|}
\hline \multicolumn{5}{|c|}{ On Geithner's Schedule } & \multicolumn{3}{|c|}{ Not on Geithner's Schedule (25 Largest) } \\
\hline & & Base & & & & & \\
\hline Firm & Occurrences & Sample & CAR $[0,10]$ & Total Assets (\$Bn) & Firm & CAR $[0,10]$ & Total Assets (\$Bn) \\
\hline JP MORGAN CHASE \& CO. & 14 & $\mathrm{~N}$ & 0.186 & $2,175.00$ & WELLS FARGO \& CO & 0.124 & $1,310.00$ \\
\hline CITIGROUP INCO. & 34 & $\mathrm{~N}$ & 0.743 & $1,938.00$ & FREDDIE MAC & 0.659 & 835.60 \\
\hline BANK OF AMERICA CORP. & 4 & $\mathrm{~N}$ & 0.168 & $1,818.00$ & US BANCORP & 0.078 & 265.90 \\
\hline FANNIE MAE & 1 & $\mathrm{~N}$ & 1.008 & 908.50 & SUNTRUST BANKS INCO. & 0.200 & 189.10 \\
\hline THE GOLDMAN SACHS GPIN. & 10 & $\mathrm{~N}$ & 0.192 & 876.20 & SLM CORP. & 0.064 & 168.80 \\
\hline MORGAN STANLEY & 9 & $\mathrm{~N}$ & 0.224 & 658.80 & CAPITAL ONE FINL.CORP. & -0.053 & 165.90 \\
\hline PNC FINL.SVS.GP.INCO. & 3 & $\mathrm{~N}$ & 0.044 & 291.10 & BB\&T CORP. & -0.131 & 152.00 \\
\hline BANK OF NY.MELLON CORP. & 7 & $\mathrm{Y}$ & -0.095 & 237.50 & REGIONS FINL.CORP. & -0.206 & 146.20 \\
\hline STATE STREET CORP. & 1 & $\mathrm{Y}$ & 0.091 & 173.60 & FIFTH THIRD BANCORP & -0.232 & 119.50 \\
\hline AMERICAN EXPRESS CO. & 2 & $\mathrm{~N}$ & 0.029 & 122.60 & KEYCORP & 0.062 & 104.50 \\
\hline NORTHERN TRUST CORP. & 1 & $\mathrm{Y}$ & 0.117 & 82.05 & AMERIPRISE FINL.INCO. & 0.297 & 94.67 \\
\hline CME GROUP INCO. & 2 & $\mathrm{Y}$ & 0.010 & 48.16 & CIT GROUP INCO. & 0.500 & 80.45 \\
\hline NY.CMTY.BANC.INCO. & 2 & $\mathrm{~N}$ & -0.078 & 32.33 & COMERICA INCO. & 0.037 & 67.55 \\
\hline ASTORIA FINL.CORP. & 2 & $\mathrm{~N}$ & -0.132 & 21.98 & M\&T BK.CORP. & -0.045 & 65.82 \\
\hline BLACKROCK INCO. & 13 & $\mathrm{Y}$ & 0.082 & 19.91 & MARSHALL \& ILSLEY CORP. & -0.300 & 62.34 \\
\hline NYSE EURONEXT & 2 & $\mathrm{~N}$ & 0.089 & 13.28 & ZIONS BANCORPORATION & -0.255 & 54.61 \\
\hline THE NASDAQ OMX GP.INCO. & 2 & $\mathrm{Y}$ & 0.212 & 12.05 & HUNTINGTON BCSH.INCO. & -0.073 & 54.35 \\
\hline THE BLACKSTONE GROUP LP. & 6 & $\mathrm{Y}$ & 0.345 & 8.41 & HUDSON CITY BANC.INCO. & -0.231 & 54.09 \\
\hline PROVIDENT FINL.SVS.INCO. & 2 & $\mathrm{Y}$ & -0.145 & 6.51 & CHARLES SCHWAB CORP. & -0.141 & 51.17 \\
\hline LAZARD LTD. & 1 & $\mathrm{Y}$ & 0.126 & 2.79 & MF GLOBAL LTD. & -0.180 & 49.18 \\
\hline MOODY'S CORP. & 2 & $\mathrm{~N}$ & 0.114 & 1.55 & E*TRADE FINANCIAL CORP. & 0.051 & 47.50 \\
\hline OCH-ZIFF CAP.MAN.GP.LLC. & 1 & $\mathrm{~N}$ & 0.107 & 1.02 & DISCOVER FINANCIAL SVS. & 0.122 & 39.20 \\
\hline BEACON FED.BANC.INCORP. & 1 & $\mathrm{Y}$ & 0.039 & 1.02 & POPULAR INCO. & -0.194 & 38.53 \\
\hline FEDERATED INVRS.INCO. & 1 & $\mathrm{Y}$ & 0.065 & 0.85 & SYNOVUS FINL.CORP. & -0.031 & 35.62 \\
\hline EVERCORE PARTNERS INCO. & 1 & $\mathrm{Y}$ & 0.485 & 0.68 & FIRST HORIZON NAT. CORP. & -0.124 & 31.02 \\
\hline
\end{tabular}

Panel B: Personal Connections

\begin{tabular}{|c|c|c|c|c|c|c|c|}
\hline \multicolumn{5}{|c|}{ Personal Connection to Geithner } & \multicolumn{3}{|c|}{ No Personal Connection (21 Largest) } \\
\hline & & Base & & & & & \\
\hline Firm & Connections & Sample & CAR $[0,10]$ & Total Assets (\$Bn) & Firm & CAR $[0,10]$ & Total Assets (\$Bn) \\
\hline JP MORGAN CHASE \& CO. & 5 & $\mathrm{~N}$ & 0.186 & $2,175.00$ & FREDDIE MAC & 0.659 & 835.60 \\
\hline CITIGROUP INCO. & 9 & $\mathrm{~N}$ & 0.743 & $1,938.00$ & US BANCORP & 0.078 & 265.90 \\
\hline BANK OF AMERICA CORP. & 1 & $\mathrm{~N}$ & 0.168 & $1,818.00$ & BANK OF NY.MELLON CORP. & -0.095 & 237.50 \\
\hline WELLS FARGO \& CO & 1 & $\mathrm{~N}$ & 0.124 & $1,310.00$ & SUNTRUST BANKS INCO. & 0.200 & 189.10 \\
\hline FANNIE MAE & 1 & $\mathrm{~N}$ & 1.008 & 908.50 & STATE STREET CORP. & 0.091 & 173.60 \\
\hline THE GOLDMAN SACHS GPIN. & 8 & $\mathrm{~N}$ & 0.192 & 876.20 & SLM CORP. & 0.064 & 168.80 \\
\hline MORGAN STANLEY & 3 & $\mathrm{~N}$ & 0.224 & 658.80 & BB\&T CORP. & -0.131 & 152.00 \\
\hline PNC FINL.SVS.GP.INCO. & 1 & $\mathrm{~N}$ & 0.044 & 291.10 & REGIONS FINL.CORP. & -0.206 & 146.20 \\
\hline CAPITAL ONE FINL.CORP. & 1 & $\mathrm{~N}$ & -0.053 & 165.90 & FIFTH THIRD BANCORP & -0.232 & 119.50 \\
\hline AMERICAN EXPRESS CO. & 1 & $\mathrm{~N}$ & 0.029 & 122.60 & KEYCORP & 0.062 & 104.50 \\
\hline CIT GROUP INCO. & 2 & $\mathrm{Y}$ & 0.500 & 80.45 & AMERIPRISE FINL.INCO. & 0.297 & 94.67 \\
\hline M\&T BK.CORP. & 1 & $\mathrm{~N}$ & -0.045 & 65.82 & NORTHERN TRUST CORP. & 0.117 & 82.05 \\
\hline POPULAR INCO. & 1 & Y & -0.194 & 38.53 & COMERICA INCO. & 0.037 & 67.55 \\
\hline BLACKROCK INCO. & 2 & $\mathrm{Y}$ & 0.082 & 19.91 & MARSHALL \& ILSLEY CORP. & -0.300 & 62.34 \\
\hline NYSE EURONEXT & 1 & $\mathrm{~N}$ & 0.089 & 13.28 & ZIONS BANCORPORATION & -0.255 & 54.61 \\
\hline THE NASDAQ OMX GP.INCO. & 1 & $\mathrm{Y}$ & 0.212 & 12.05 & HUNTINGTON BCSH.INCO. & -0.073 & 54.35 \\
\hline FRANKLIN RESOURCES INCO. & 1 & $\mathrm{~N}$ & 0.046 & 9.18 & HUDSON CITY BANC.INCO. & -0.231 & 54.09 \\
\hline THE BLACKSTONE GROUP LP. & 4 & $\mathrm{Y}$ & 0.345 & 8.41 & CHARLES SCHWAB CORP. & -0.141 & 51.17 \\
\hline FORTRESS INV.GP.LLC. & 1 & Y & -0.131 & 1.17 & MF GLOBAL LTD. & -0.180 & 49.18 \\
\hline CARVER BANCORP INCO. & 1 & Y & -0.116 & 0.79 & CME GROUP INCO. & 0.010 & 48.16 \\
\hline GAMCO INVESTORS INCO. & 1 & $\mathrm{Y}$ & -0.147 & 0.67 & E*TRADE FINANCIAL CORP. & 0.051 & 47.50 \\
\hline
\end{tabular}


Personal Connections of Timothy Geithner to Financial Firms

The table lists firms to which Timothy Geithner has connections through one or more individuals. The connections are compiled from March 2009 relationship maps on muckety.com. The connections represent either known connections between Geithner and an individual or potential connections in that Geithner and the individual are associated with the same organization.

\begin{tabular}{|c|c|c|c|c|c|}
\hline Firm & Connected Person & Position with Firm & Connection to Geithner & $\begin{array}{l}\text { Geithner's Position } \\
\text { with Connection }\end{array}$ & $\begin{array}{c}\text { Connected Person's } \\
\text { Position with Connection }\end{array}$ \\
\hline American Express & Kenneth I. Chenault & chairman \& CEO & National Academy Foundation & director & director \\
\hline American Express & Kenneth I. Chenault & chairman \& CEO & Partnership for New York City & board member & vice chair \\
\hline Bank of America & Patricia E. Mitchell & director & Council on Foreign Relations & member & member \\
\hline BlackRock & James E. Rohr & director & RAND Corporation & trustee & trustee \\
\hline BlackRock & John A. Thain & director & Unofficial Adviser to Geithner & NA & NA \\
\hline Blackstone Group & J. Tomilson Hill & vice chairman & Council on Foreign Relations & member & director \\
\hline Blackstone Group & Paul H. O'Neill & special adviser & RAND Corporation & trustee & trustee \\
\hline Blackstone Group & Peter G. Peterson & chairman and co-founder & Unofficial Adviser to Geithner & NA & NA \\
\hline Blackstone Group & Richard E. Salomon & adv. board chair, alt. asset mgt. & Council on Foreign Relations & member & vice chairman \\
\hline Capital One & Patrick W. Gross & director & Council on Foreign Relations & member & member \\
\hline Carver Bancorp & Deborah C. Wright & chairman \& president \& CEO & Partnership for New York City & board member & director \\
\hline CIT Group & Jeffrey M. Peek & chairman \& CEO & Partnership for New York City & board member & director \\
\hline CIT Group & Seymour Sternberg & director & Council on Foreign Relations & member & member \\
\hline CIT Group & Seymour Sternberg & director & Partnership for New York City & board member & director \\
\hline Citigroup & Alain J.P. Belda & director & Partnership for New York City & board member & director \\
\hline Citigroup & C. Michael Armstrong & director & Council on Foreign Relations & member & member \\
\hline Citigroup & Judith Rodin & director & Council on Foreign Relations & member & member \\
\hline Citigroup & Kenneth T. Derr & director & Council on Foreign Relations & member & member \\
\hline Citigroup & Michael B.G. Froman & managing director & Council on Foreign Relations & member & member \\
\hline Citigroup & Pamela P. Flaherty & director, corporate citizenship & Council on Foreign Relations & member & member \\
\hline Citigroup & Richard D. Parsons & chairman & Partnership for New York City & board member & chair emeritus, director \\
\hline Citigroup & Robert E. Rubin & director & Geithner is Protégé of Rubin & NA & NA \\
\hline Citigroup & Roberto H. Ramirez & director & Federal Reserve Bank of New York & president & int'l advisory board \\
\hline Fannie Mae & Herbert M. Allison Jr. & President \& CEO & Economic Club of New York & trustee & trustee \\
\hline Fannie Mae & Herbert M. Allison Jr. & President \& CEO & Partnership for New York City & board member & director \\
\hline Fortress Inv. Group & Richard N. Haass & director & Council on Foreign Relations & member & president \\
\hline Franklin Resources & Anne M. Tatlock & director & Council on Foreign Relations & member & member \\
\hline GAMCO Investors & Eugene R. McGrath & director & Economic Club of New York & trustee & trustee \\
\hline Goldman Sachs & Ashton B. Carter & consultant & Council on Foreign Relations & member & member \\
\hline Goldman Sachs & E. Gerald Corrigan & managing director & Unofficial Adviser to Geithner & NA & NA \\
\hline Goldman Sachs & James A. Johnson & director & Council on Foreign Relations & member & member \\
\hline Goldman Sachs & John C. Whitehead & foundation chairman & International Rescue Committee & trustee & trustee \\
\hline Goldman Sachs & Lloyd C. Blankfein & chairman \& CEO & Partnership for New York City & board member & director \\
\hline Goldman Sachs & Robert D. Hormats & vice chairman, GS International & Economic Club of New York & trustee & trustee, vice chair \\
\hline Goldman Sachs & Ruth J. Simmons & director & Council on Foreign Relations & member & member \\
\hline Goldman Sachs & Stephen Friedman & director & Council on Foreign Relations & member & director \\
\hline Goldman Sachs & Stephen Friedman & director & Federal Reserve Bank of New York & president & chair \\
\hline JPMorgan Chase & Andrew D. Crockett & executive committee member & Group of Thirty & member & member \\
\hline JPMorgan Chase & Ellen V. Futter & director & Council on Foreign Relations & member & member \\
\hline JPMorgan Chase & James Dimon & chairman \& CEO & Federal Reserve Bank of New York & president & director \\
\hline JPMorgan Chase & James Dimon & chairman \& CEO & Partnership for New York City & board member & director \\
\hline JPMorgan Chase & Ratan N. Tata & international advisory board & RAND Corporation & trustee & trustee \\
\hline JPMorgan Chase & William M. Daley & chairman midwest region & Council on Foreign Relations & member & member \\
\hline M\&T Bank & Robert G. Wilmers & chairman \& CEO & Council on Foreign Relations & member & member \\
\hline Morgan Stanley & Frederick B. Whittemore & partner \& managing director & Council on Foreign Relations & member & trustee \\
\hline Morgan Stanley & John J. Mack & chairman \& CEO & Partnership for New York City & board member & director \\
\hline Morgan Stanley & Philip Lader & senior adviser & RAND Corporation & trustee & trustee \\
\hline NASDAQ & Robert Greifeld & president \& CEO & Partnership for New York City & board member & director \\
\hline NYSE & Shirley Ann Jackson & director & Council on Foreign Relations & member & director \\
\hline PNC Fin. Services & James E. Rohr & chairman \& CEO & RAND Corporation & trustee & trustee \\
\hline Popular & Richard L. Carrion & chairman, president, \& CEO & Federal Reserve Bank of New York & president & director \\
\hline Wells Fargo & Donald B. Rice & director & RAND Corporation & trustee & trustee \\
\hline
\end{tabular}


The table compares firms in the sample headquartered in New York City with firms in the sample headquartered elsewhere. CAR [0,10] is the cumulative abnormal return for the firm surrounding the announcement of Geithner as treasury secretary. Total assets are for the year 2008 from Worldscope.

\begin{tabular}{|c|c|c|c|c|c|c|}
\hline \multicolumn{4}{|c|}{ New York } & \multicolumn{3}{|c|}{ Non-New York (Largest 45) } \\
\hline & Base & & & & & \\
\hline Firm & Sample & CAR $[0,10]$ & Total Assets (\$Bn) & Firm & CAR $[0,10]$ & Total Assets (\$Bn) \\
\hline JP MORGAN CHASE \& CO. & $\mathrm{N}$ & 0.186 & $2,175.00$ & BANK OF AMERICA CORP. & 0.168 & $1,818.00$ \\
\hline CITIGROUP INCO. & $\mathrm{N}$ & 0.743 & $1,938.00$ & WELLS FARGO \& CO & 0.124 & $1,310.00$ \\
\hline THE GOLDMAN SACHS GPIN. & $\mathrm{N}$ & 0.192 & 876.20 & FANNIE MAE & 1.008 & 908.50 \\
\hline MORGAN STANLEY & $\mathrm{N}$ & 0.224 & 658.80 & FREDDIE MAC & 0.659 & 835.60 \\
\hline BANK OF NY.MELLON CORP. & $\mathrm{Y}$ & -0.095 & 237.50 & PNC FINL.SVS.GP.INCO. & 0.044 & 291.10 \\
\hline AMERICAN EXPRESS CO. & $\mathrm{N}$ & 0.029 & 122.60 & US BANCORP & 0.078 & 265.90 \\
\hline CIT GROUP INCO. & $\mathrm{Y}$ & 0.500 & 80.45 & SUNTRUST BANKS INCO. & 0.200 & 189.10 \\
\hline E*TRADE FINANCIAL CORP. & $\mathrm{Y}$ & 0.051 & 47.50 & STATE STREET CORP. & 0.091 & 173.60 \\
\hline BLACKROCK INCO. & $\mathrm{Y}$ & 0.082 & 19.91 & SLM CORP. & 0.064 & 168.80 \\
\hline JEFFERIES GP.INCO. & $\mathrm{N}$ & 0.071 & 19.60 & CAPITAL ONE FINL.CORP. & -0.053 & 165.90 \\
\hline ICAHN ENTERPRISES LP. & $\mathrm{Y}$ & 0.764 & 18.82 & BB\&T CORP. & -0.131 & 152.00 \\
\hline NYSE EURONEXT & $\mathrm{N}$ & 0.089 & 13.28 & REGIONS FINL.CORP. & -0.206 & 146.20 \\
\hline THE NASDAQ OMX GP.INCO. & $\mathrm{Y}$ & 0.212 & 12.05 & FIFTH THIRD BANCORP & -0.232 & 119.50 \\
\hline THE BLACKSTONE GROUP LP. & $\mathrm{Y}$ & 0.345 & 8.41 & KEYCORP & 0.062 & 104.50 \\
\hline SIGNATURE BK. & $\mathrm{Y}$ & -0.064 & 7.11 & AMERIPRISE FINL.INCO. & 0.297 & 94.67 \\
\hline LABRANCHE \& CO.INCO. & $\mathrm{Y}$ & 0.127 & 3.73 & NORTHERN TRUST CORP. & 0.117 & 82.05 \\
\hline INTERVEST BCSH.CORP. & $\mathrm{Y}$ & -0.259 & 2.26 & COMERICA INCO. & 0.037 & 67.55 \\
\hline STERLING BANC. & $\mathrm{Y}$ & -0.137 & 2.19 & M\&T BK.CORP. & -0.045 & 65.82 \\
\hline FINL.FED.CORP. & $\mathrm{Y}$ & 0.277 & 1.94 & MARSHALL \& ILSLEY CORP. & -0.300 & 62.34 \\
\hline INV.TECH.GP. & $\mathrm{Y}$ & 0.164 & 1.68 & ZIONS BANCORPORATION & -0.255 & 54.61 \\
\hline ALLBERN.HLDG.LP. & $\mathrm{Y}$ & 0.401 & 1.60 & HUNTINGTON BCSH.INCO. & -0.073 & 54.35 \\
\hline MOODY'S CORP. & $\mathrm{Y}$ & 0.114 & 1.55 & HUDSON CITY BANC.INCO. & -0.231 & 54.09 \\
\hline NAT.FINL.PTNS.CORP. & $\mathrm{Y}$ & 0.989 & 1.52 & CHARLES SCHWAB CORP. & -0.141 & 51.17 \\
\hline FORTRESS INV.GP.LLC. & $\mathrm{Y}$ & -0.131 & 1.17 & MF GLOBAL LTD. & -0.180 & 49.18 \\
\hline GFI GROUP INCO. & $\mathrm{Y}$ & -0.278 & 1.09 & CME GROUP INCO. & 0.010 & 48.16 \\
\hline BGC PARTNERS INCO. & $\mathrm{Y}$ & 0.328 & 1.07 & DISCOVER FINANCIAL SVS. & 0.122 & 39.20 \\
\hline OCH-ZIFF CAP.MAN.GP.LLC. & $\mathrm{Y}$ & 0.107 & 1.02 & POPULAR INCO. & -0.194 & 38.53 \\
\hline MSCI INCO. & $\mathrm{Y}$ & 0.090 & 1.02 & SYNOVUS FINL.CORP. & -0.031 & 35.62 \\
\hline BERKSHIRE BANCORP INCO. & $\mathrm{Y}$ & -0.190 & 0.91 & NY.CMTY.BANC.INCO. & -0.078 & 32.33 \\
\hline CARVER BANCORP INCO. & $\mathrm{Y}$ & -0.116 & 0.79 & FIRST HORIZON NAT.CORP. & -0.124 & 31.02 \\
\hline BROADPOINT SECS.GP.INCO. & $\mathrm{Y}$ & 0.204 & 0.69 & THE STUDENT LN.CORP. & 0.321 & 28.14 \\
\hline EVERCORE PARTNERS INCO. & $\mathrm{Y}$ & 0.485 & 0.68 & INTACT.BCK.GP.INCORP. & 0.073 & 28.00 \\
\hline MEDALLION FINL.CORP. & $\mathrm{Y}$ & 0.146 & 0.65 & THE COLO.BANCGROUP INCO. & 0.020 & 25.50 \\
\hline KBW INCO. & $\mathrm{Y}$ & -0.382 & 0.57 & ASSOCIATED BANC-CORP & -0.056 & 24.19 \\
\hline GLG PARTNERS INCO. & $\mathrm{Y}$ & -0.012 & 0.49 & BOK FINL.CORP. & -0.065 & 22.73 \\
\hline DUFF \& PHELPS CORP. & $\mathrm{Y}$ & 0.438 & 0.35 & ASTORIA FINL.CORP. & -0.132 & 21.98 \\
\hline COHEN \& STEERS INCO. & $\mathrm{Y}$ & 0.204 & 0.28 & RAYMOND JAMES FINL.INCO. & -0.020 & 20.62 \\
\hline GREENHILL \& CO.INCO. & $\mathrm{Y}$ & -0.064 & 0.23 & PEOPLES UTD.FINL.INCO. & -0.174 & 20.17 \\
\hline MARKETAXESS HDG.INCO. & $\mathrm{Y}$ & 0.040 & 0.21 & FIRST BANC. & -0.093 & 19.49 \\
\hline COWEN GROUP INCORPORATED & $\mathrm{Y}$ & 0.057 & 0.20 & CAPITALSOURCE INCO. & 0.135 & 18.41 \\
\hline CMS BANCORP INCO. & $\mathrm{Y}$ & 0.100 & 0.20 & COMMERCE BCSH.INCO. & -0.106 & 17.53 \\
\hline PZENA INV.MAN.INCO. & $\mathrm{Y}$ & -0.151 & 0.06 & WEBSTER FINL.CORP. & 0.067 & 17.39 \\
\hline EPOCH HOLDING CORP. & $\mathrm{Y}$ & 0.030 & 0.05 & FIRST CTZN.BCSH.INCO. & -0.053 & 16.75 \\
\hline RODMAN \& RENSHAW CAP.GP. & $\mathrm{Y}$ & 0.217 & 0.05 & TCF FINANCIAL CORP. & -0.026 & 16.74 \\
\hline SIEBERT FINANCIAL CORP. & $\mathrm{Y}$ & -0.031 & 0.04 & AMERICREDIT CORP. & 0.363 & 16.23 \\
\hline
\end{tabular}


The table lists firms in the sample not listed in Appendix Table A4. The firms are listed in descending order of size (total assets).

\begin{tabular}{|c|c|c|c|c|c|c|}
\hline City National & Amcore Financial & Wilshire Banc. & Stewart Info.Svs. & Dollar Financial & Comm Bancorp & Greene County Banc. \\
\hline Fulton Financial & Fed.Agri.Mge. & First Regl.Banc. & Oritani Financial & Legacy Bancorp & Landmark Bancorp & LSB Finl. \\
\hline TD Ameritrade & Irwin Finl. & Fcstone Group & Firstbank & Nat.Bankshares & Central Jersey Bancorp & River Valley Bancorp \\
\hline Cullen Fo.Bankers & First Merchants & Ameris Bancorp & Centrue Finl. & Fox Chase Bancorp & Monarch Finl.Hdg. & WSB Financial Gp. \\
\hline Ictl.Ex. & Pncl.Finl.Ptns. & Lakeland Finl. & Horizon Financial & Eaton Vance & Parke Bancorp & Summit State Bank \\
\hline Valley National Bancorp & PMI Group & Camden Nat. & Mutualfirst Finl. & Patriot Nat.BanInc & Northeast Bancorp & Coml.Nat.Finl. \\
\hline Flagstar Bancorp & Banner & Seacoast Bkg.Fla. & Alliance Finl. & Washington Banking Co. & Pamrapo Ban & Patriot Cap.Fdg. \\
\hline Susquehanna Bcsh. & 1st Source & First Finl. & Peapack-Gladstone Finl. & Clifton Svg.Banc. & Sun American Bancorp & Citizens First \\
\hline Sth.Finl.Gp. & First Busey & Cascade Bancorp & PAB Bankshares & Peoples Finl. & Capital Southwest & Pathfinder Banc. \\
\hline UCBH Holdings & S \& T Bancorp & Enter.Finl.Svs. & SEI Invs.Co. & Unity Bancorp & Cmty.Vly.Banc. & Liberty Bancorp \\
\hline Bancorpsouth & Taylor Cap.Gp. & United Wstn.Banc. & Mrch.Bcsh. & WGNB & Cowlitz Bancorporation & Rome Bancorp \\
\hline Sterling Finl. & Frontier Finl. & Viewpoint Financial Gp. & Centerstate Bks.of Fla. & Riverview Bancorp & BCB Bancorp & Cheviot Finl. \\
\hline KKR Financial Hdg.Llc & Dime Cmty.Bcsh. & Mercantile Bk. & Sierra Bancorp & Cmty.Bk.Shs.of Indna. & Alliance Bksh. & Glen Burnie Bancorp \\
\hline Whitney Holding & Benl.Mut.Banc. & Farmers Capital Bk. & City Bank & 1st.Sth.Banc. & Vil.Bk.\&.Tst.Finl. & Firstcity Finl. \\
\hline East Ws.Banc. & Westamerica Ban & Macatawa Bank & Horizon Banc. & North Vly.Ban & Central Banc. & Louisiana Bancorp \\
\hline Wilmington Tst. & Flushing Finl. & Penn.Com.Banc. & Pulaski Financial & 1st.Pactrust Banc. & Community Partners Banc. & Oak Ridge Finl.Svs. \\
\hline Legg Mason & Chemical Finl. & First Cmty.Bcsh. & Ctzn.\& Nthn. & PVF Capital & Pico Hdg. & Old Line Bcsh. \\
\hline Wash.Fed. & Bancfirst & Banctrust Finl.Gp. & First Mariner Ban & Ames Nat. & American River Bksh. & MSB Financial \\
\hline Cathay Gen.Bancorp & Hanmi Finl. & Univest of Penn. & Hawthorn Bcsh. & K-Fed Bancorp & First Fed.Bksh. & Ezcorp \\
\hline Firstmerit & First Finl.Banc. & Kearny Financial & First Security Gp. & Federated Invrs. & Community Ctl.Bk. & Somerset Hills Banc. \\
\hline UMB Finl. & Renasant & Ocwen Finl. & The 1st.of Lng.Isl. & C\&F Finl. & Encore Cap.Gp. & Sanders Mos.Har.Gp. \\
\hline TFS Financial & Heartland Finl.Usa & Newbridge Bancorp & Colony Bankcorp & SI Finl.Gp. & The Bank Holdings & Monarch Cmty.Banc. \\
\hline Bank of Hawaii & Independent Bk. & Fnb United & First Financial Nw. & Nwh.Thrift Bcsh. & 1st Cnt.Ban & Thomas Weisel Ptns.Gpin. \\
\hline Wintrust Financial & Sun Bancorp & Center Finl. & Piper Jaffray Cos. & Bridge Bancorp & Hampden Bancorp & Amer.Phys.Ser.Gp. \\
\hline Doral Financial & Advanta & Trico Bcsh. & Tennessee Com.Banc. & Tradestation Gp. & Oneida Finl. & Bay National \\
\hline Privatebancorp & Midwest Banc Hdg. & Peoples Banc. & 1st.Marblehead & Harleysville Svg.Finl. & Southcoast Finl. & Atlantic Bancgroup \\
\hline SVB Financial Group & Trustco Bk.Ny & ESB Finl. & Bofi Holding & Monroe Ban & Colonial Bksh. & First Csh.Finl.Svs. \\
\hline Trustmark & Ampal-Amer.Isr. & Cadence Financial & German Amer.Banc. & Ctzn.Sth.Bkg. & Evans Bancorp & Optimumbank Hdg. \\
\hline Pacific Cap.Banc. & Bank Mut. & Citizens 1st.Banc. & Cash Am.Intl. & Rainier Pac.Finl.Gp.Inco & Chicopee Bancorp & Cmty.Shores Bk. \\
\hline Nat.Penn Bcsh. & Wsfs Finl. & 1st.Defiance Finl. & Appalachian Bcsh. & First Nat.Bcsh. & NB\&T Finl.Gp. & Kentucky First Fed.Banc. \\
\hline 1st.Niag.Finl.Gp. & First Ste.Ban & Knight Capital Gp. & Abington Bancorp & Hingham Instn.For Svg. & First Key.Finl. & 1st.Fed.of Nthn.Mi.Banc. \\
\hline Mgic Investment & Integra Bank & Finl.Institutions & Harrington Ws.Fgp. & Herit.Oaks Banc. & Magyar Bancorp & Bank of Soca. \\
\hline Franklin Resources & First Pl.Finl. & Amer.West Ban & First Cal.Finl.Gp. & Marlin Bus.Svs. & Norwood Finl. & Mayflower Bancorp \\
\hline Prosperity Bcsh. & Janus Capital Gp. & Smithtown Banc. & Enterprise Bancorp & Primus Guaranty Ltd. & Heritage Financial Group & FPB Bancorp \\
\hline MB Finl. & Tierone & Oppenheimer Hdg. & Pac.Merc.Ban & 1st.Fed.Bcsh.of Ark.Inco & 1st.Cmty.Bk.of Am. & Safegd.Scientifics \\
\hline Umpqua Hdg. & Sandy Spring Banc. & Oceanfirst Finl. & Royal Bcsh.of Penn. & Amer.Nat.Bksh. & PSB Holdings & GS Financial \\
\hline Utd.Cmty.Bks. & Equifax & Parkvale Finl. & Princeton Nat.Banc. & Community Capital & Brooklyn Fed.Banc. & Park Bancorp \\
\hline First Midwest Banc. & Affiliated Mgrs.Gp.Inc & Sthn.Cmty.Finl. & Bank of Granite & Ohio Valley Banc & Elmira Svg.Bk.Fsb & Triangle Capital \\
\hline FNB & Bank of The Ozarks & The Bancorp & Bryn Mawr Bank & United Panam Finl. & Citizens Cmty.Banc. & VSB Bancorp NY \\
\hline Corus Bankshares & First Finl.Bksh. & Northfield Bancorp & Credit Accep. & Waddell \& Reed Finl.Inc & Central Va.Bksh. & Intersections \\
\hline Newalliance Bcsh. & Townebank & Fidelity Sthn. & HMN Financial & Bank of Commerce Hdg. & North Ctl.Bcsh. & Oh.Legacy \\
\hline Fid.Nat.Financial & Columbia Bkg.Sys. & Cardinal Finl. & LNB BanInc & Citizens Co. & First State Finl. & Nicholas Financial \\
\hline Capitol Fed.Finl. & Hampton Roads Bksh. & Ste.Banc. & Triad Gty. & LSB & Asta Funding & First Bankshares \\
\hline Utd.Bksh. & Old Second Banc. & Arrow Finl. & Columbia Bancorp & United Security Bcsh. & World Acceptance & Ffd Finl. \\
\hline Santander Bancorp & Provident Ny.Banc. & Porter Bancorp & CFS Bancorp & Meta Financial Gp. & Ameriana Bancorp & Main Street Cap. \\
\hline Old Nat.Banc.(Indiana) & Wash.Tst.Banc. & Capital Bk. & Dearborn Banc. & Auburn Nat.BanInc & Plumas Banc. & Commercefirst Banc. \\
\hline Radian Gp. & First Finl.Hdg. & Cascade Finl. & Westfield Finl. & Ctl.Vly.Cmty.Banc. & Mackinac Financial & Bank of Mckenney \\
\hline Bstn.Priv.Finl.Hdg. & Independent Bk. & Summit Finl.Gp. & Pacific Cont. & TF Financial & Adv.Am.Csh.Adv.Cntrs. & Carolina Trust Bank \\
\hline Hancock Holding Co. & Community Tst.Banc. & Provident Finl.Hdg. & Roma Financial & Pac.Premier Banc. & Wsb Holdings & Am.1st.Tax Exem.Invrs.Lp \\
\hline Northwest Banc. & Green Bankshares & Sy Bancorp & Cmwl.Bksh. & Premier Finl.Bancorp Inc & Scty.Nat.Finl. & Osage Bancshares \\
\hline CVB Financial & Simmons First Nat. & First Utd. & First Ctzn.Banc & Home Federal Banc. & United Bancorp Oh. & QC Holdings \\
\hline Moneygram Intl. & Mainsource Finl.Gp. & TIB Finl. & Wainwright Bk.\& Tst.Co. & Fidelity Ban & Sussex Bancorp & JMP Group \\
\hline Provident Bksh. & Southwest Bancorp & QCR Hdg. & Bank of Marin Bancorp & Resource Am. & Intl.Assets & Investors Title Co. \\
\hline Provident Finl.Svs. & Security Bank & First M \& F & Shore Bcsh. & Tidelands Bcsh. & Union Bankshares & Microfinancial \\
\hline 1st.Cmwl.Finl. & Eurobancshares & Consumer Prtf.Svs. & Eastern Va.Bksh. & Peoples Cmty.Banc. & Jacksonvl.Banc.Fla. & Cougar Biotech. \\
\hline Investors Bancorp & Lazard Ltd. & Suffolk Banc. & CNB Finl. & Access National & First Cap.Bancorp & Arbinet Thexchange \\
\hline Oriental Finl.Gp. & SCBT Financial & Encore Bancshares & First Finl.Ser. & Codorus Vly.Banc. & Prvt.Cmty.Bcsh. & Westwood Hdg.Gp. \\
\hline Mastercard & First Bancorp & Bnc Bancorp & Beacon Fed.Banc.In & Tower Finl. & Newport Bancorp & US Global Invrs. \\
\hline Bankatlantic Banc. & T Rowe Price Gp. & Metrocorp Bcsh. & Center Banc. & Sthn.First Bcsh. & Sthn.Nat.Banc.of Va.Inco & Dia.Hill Inv.Gp. \\
\hline Capitol Banc.Ltd. & Va.Com.Bancorp & Bankfinancial & Essa Bancorp & Timberland Banc. & Ntheast.Cmty.Banc. & Paulson Cap. \\
\hline Iberiabank & Southside Bcsh. & Mbt Finl. & Northrim Bancorp & Ocean Shore Co. & WVS Finl. & Arrowhead Resh. \\
\hline Western Union Co.(The) & Cobiz Financial & West Ban & Atl.Sthn.Finl.Gp. & Gamco Investors & All.Banc.of (Penn.) & Kent Finl.Svs. \\
\hline Glacier Bancorp & Berk.Hills Banc. & Bank of Florida & Atlantic Cst.Fed. & Guaranty Fed.Bcsh. & Southern Mo.Banc. & Community Bancorp \\
\hline Penson Worldwide & Nara Banc. & Compucredit & Severn Banc. & Bch.First Nat.Bcsh. & Abigail Adams Nat.Banc. & Bankunited Finl. \\
\hline Harleysville Nat. & Great Sthn.Bancorp & Banc.Rhode Isl. & Middleburg Finl. & Prtf.Rec.Assocs. & Britton \& Koontz Cap. & Benjamin Frank.Banc.Inco \\
\hline Central Pac.Finl. & Lakeland Bancorp & Rockville Finl. & Compass Diversified Hdg. & Rurban Finl. & Asset Accep.Cap. & W Holding Company \\
\hline NBT Bancorp & United Cmty.Finl. & Yadkin Valley Finl. & Optionsxpress Hdg. & Community West Bcsh. & Broadway Financial & Vineyard National Banc. \\
\hline Wesbanco & Brookline Bancorp & Stifel Finl. & Hopfed Bancorp & First Clover Leaf Finl. & Lake Shore Bancorp & Cape Fear Bank \\
\hline Western All.Ban & Home Bancshares & NASB Finl. & Crescent Financial & Penns Woods Banc. & Wayne Svg.Bcsh. & Amer.Cmty.Bcsh. \\
\hline Cmty.Bk.Sy. & Union Bankshares & Heritage Com. & Ameriserv Finl.Inc & First Cmty. & Carrollton Banc. & \\
\hline Anchor Banc.Wi. & Newstar Financial & Temecula Vly.Banc. & Coop.Bankshares & Amer.Bancorp of $\mathrm{Nj}$. & Jeffersonville Bancorp & \\
\hline Texas Capital Bcsh. & City Co. & Eagle Banc. & Rep.First Banc.Inco & Carolina Bk.Hdg. & Calamos Asset Man. & \\
\hline SWS Gp. & West Coast Bancorp & Premier West Bancorp & Bridge Cap.Hdg. & Utd.Bcsh.Ohio & Cal.1st.Nat.Bancorp & \\
\hline Sterling Bcsh. & Cap.City Bk.Gp. & Preferred Bank & Heritage Financial & New Century Banc. & United Community Bancorp & \\
\hline
\end{tabular}


Appendix Table A5

Connections to Geithner and Stock Price Reactions to Treasury Secretary Announcement, Full Sample

The table presents stock returns of financial firms around the announcement of Barack Obama's nomination of Timothy Geithner as Treasury Secretary. Event day 0 is November 21, 2008 from 3pm (when the news leaked) to market closing; the announcement was made on event day 1 . Abnormal returns are calculated using the market model with an estimation window of 250 trading days ending 30 days prior to event day 0 . Schedule connections indicate meetings between the firm's executives and Geithner during 2007-08; personal connections indicate shared board memberships between the firm's executives and Geithner; New York connections indicate firms headquartered in New York City. Asterisks denote significance levels of a two-tailed t-test $(* * *=1 \%$, $* *=5 \%, *=10 \%)$.

\begin{tabular}{|c|c|c|c|c|c|c|c|c|c|c|}
\hline \multirow[b]{2}{*}{ Event Day } & \multirow[b]{2}{*}{ Date } & \multicolumn{3}{|c|}{ Schedule Connections } & \multicolumn{3}{|c|}{ Personal Connections } & \multicolumn{3}{|c|}{ New York Connections } \\
\hline & & Conn. & Non-Conn. & Difference & Conn. & Non-Conn. & Difference & Conn. & Non-Conn. & Difference \\
\hline 0 & $11 / 21 / 2008$ & 0.093 & 0.047 & $0.046^{* * *}$ & 0.096 & 0.047 & $0.049 * * *$ & 0.089 & 0.046 & $0.043 * * *$ \\
\hline 1 & $11 / 24 / 2008$ & 0.165 & 0.054 & $0.111 * * *$ & 0.185 & 0.054 & $0.131 * * *$ & 0.107 & 0.055 & $0.052 * * *$ \\
\hline 2 & $11 / 25 / 2008$ & 0.032 & 0.015 & 0.017 & 0.047 & 0.015 & 0.032 & 0.033 & 0.014 & 0.019 \\
\hline 3 & $11 / 26 / 2008$ & 0.087 & 0.042 & $0.045 * *$ & 0.076 & 0.043 & 0.034 & 0.085 & 0.040 & $0.045 * * *$ \\
\hline 4 & $11 / 28 / 2008$ & 0.051 & 0.018 & $0.033 * *$ & 0.054 & 0.018 & $0.036 * *$ & 0.021 & 0.019 & 0.002 \\
\hline 5 & $12 / 1 / 2008$ & -0.151 & -0.083 & $-0.068 * * *$ & -0.165 & -0.083 & $-0.082 * * *$ & -0.118 & -0.083 & $-0.034 * *$ \\
\hline 6 & $12 / 2 / 2008$ & 0.054 & 0.046 & 0.008 & 0.058 & 0.046 & 0.012 & 0.086 & 0.043 & $0.043 * * *$ \\
\hline 7 & $12 / 3 / 2008$ & 0.045 & 0.020 & 0.024 & 0.056 & 0.020 & $0.036 * *$ & 0.035 & 0.020 & 0.015 \\
\hline 8 & $12 / 4 / 2008$ & -0.009 & -0.014 & 0.005 & -0.003 & -0.015 & 0.011 & -0.021 & -0.014 & -0.008 \\
\hline 9 & $12 / 5 / 2008$ & 0.060 & 0.029 & $0.031 * *$ & 0.056 & 0.029 & $0.027 *$ & 0.054 & 0.028 & $0.026 * *$ \\
\hline 10 & $12 / 8 / 2008$ & 0.073 & 0.027 & $0.046 * *$ & 0.072 & 0.028 & $0.045 * *$ & 0.057 & 0.027 & $0.030 * *$ \\
\hline $0-10$ & (Cumulative) & 0.584 & 0.197 & $0.387 * * *$ & 0.646 & 0.197 & $0.448 * * *$ & 0.512 & 0.189 & $0.323 * * *$ \\
\hline \multicolumn{11}{|c|}{ Panel B: Cumulative abnormal returns, Full sample } \\
\hline \multirow[b]{2}{*}{ Event Day } & \multirow[b]{2}{*}{ Date } & \multicolumn{3}{|c|}{ Schedule Connections } & \multicolumn{3}{|c|}{ Personal Connections } & \multicolumn{3}{|c|}{ New York Connections } \\
\hline & & Conn. & Non-Conn. & Difference & Conn. & Non-Conn. & Difference & Conn. & Non-Conn. & Difference \\
\hline 0 & $11 / 21 / 2008$ & -0.016 & -0.015 & 0.000 & -0.025 & -0.015 & -0.010 & -0.007 & -0.016 & 0.009 \\
\hline 1 & $11 / 24 / 2008$ & 0.046 & -0.020 & $0.066 * * *$ & 0.046 & -0.020 & $0.065 * * *$ & 0.010 & -0.020 & $0.029 *$ \\
\hline 2 & $11 / 25 / 2008$ & 0.067 & -0.011 & $0.079 * * *$ & 0.080 & -0.011 & $0.091 * * *$ & 0.033 & -0.011 & $0.045 * *$ \\
\hline 3 & $11 / 26 / 2008$ & 0.097 & -0.002 & $0.099 * * *$ & 0.093 & -0.001 & $0.094 * * *$ & 0.069 & -0.003 & $0.072 * * *$ \\
\hline 4 & $11 / 28 / 2008$ & 0.131 & 0.007 & $0.124 * * *$ & 0.130 & 0.008 & $0.121 * * *$ & 0.076 & 0.007 & $0.069 * *$ \\
\hline 5 & $12 / 1 / 2008$ & 0.120 & 0.005 & $0.115 * * *$ & 0.120 & 0.005 & $0.115 * * *$ & 0.083 & 0.003 & $0.079 * * *$ \\
\hline 6 & $12 / 2 / 2008$ & 0.110 & 0.014 & $0.096 * * *$ & 0.107 & 0.015 & $0.092 * *$ & 0.113 & 0.010 & 0.103 *** \\
\hline 7 & $12 / 3 / 2008$ & 0.112 & 0.010 & $0.102 * * *$ & 0.116 & 0.011 & $0.105 * *$ & 0.111 & 0.007 & $0.104 * * *$ \\
\hline 8 & $12 / 4 / 2008$ & 0.149 & 0.022 & $0.126 * * *$ & 0.163 & 0.023 & $0.140 * * *$ & 0.130 & 0.019 & $0.111^{* * *}$ \\
\hline 9 & $12 / 5 / 2008$ & 0.150 & 0.018 & $0.132 * * *$ & 0.154 & 0.018 & $0.135 * * *$ & 0.133 & 0.014 & $0.119 * * *$ \\
\hline 10 & $12 / 8 / 2008$ & 0.161 & 0.010 & $0.151 * * *$ & 0.157 & 0.011 & $0.147 * * *$ & 0.136 & 0.006 & $0.129 * * *$ \\
\hline
\end{tabular}


Appendix Table A6

Cumulative Abnormal Returns of Connected Firms, Matching Estimators

The table reports results from various matching estimators. Panels A and B compare cumulative abnormal returns (CARs) of firms connected to Geithner with cumulative abnormal returns of non-connected firms matched by propensity score. The CAR is measured from day 0 to day 1 or from day 0 to day 10, as indicated. Matching is done in one of three ways, as indicated: by firm size, by the primary control variables (size, profitability, and leverage), or by the primary control variables plus other control variables (a TARP participation dummy, a deposit-taking dummy, and the CAR surrounding the Lehman collapse). Matching is performed as one-to-one matching without replacement. Panel C reports the weighted average estimates computed separately for every covariate cell of regressions of cumulative abnormal returns (CARs) surrounding the announcement of Geithner as Treasury Secretary on measures of connections to Geithner. Covariates are quartiles of log of total assets, profitability, and leverage, which results in 64 cells. Controls for $\log$ of total assets, profitability, and leverage are included in each regression. Standard errors are in parentheses, and asterisks denote significance levels $(* * *=1 \%$, $* *=5 \%$, $*=10 \%)$.

(4)

(5)

(6)

(7)

(8)

Panel A: Propensity-score matched, CAR [0,1]

\begin{tabular}{|c|c|c|c|c|c|c|c|c|c|}
\hline & \multicolumn{3}{|c|}{ Match on Firm Size } & \multicolumn{3}{|c|}{ Match on Primary Control Variables } & \multicolumn{3}{|c|}{ Primary Controls and Others } \\
\hline & Conn. & Non-Conn. & Difference & Conn. & Non-Conn. & Difference & Conn. & Non-Conn. & Difference \\
\hline Geithner Connections (Schedule) & 0.046 & -0.026 & $\begin{array}{c}0.072 \text { ** } \\
(0.030)\end{array}$ & 0.060 & 0.006 & $\begin{array}{c}0.054 * \\
(0.033)\end{array}$ & 0.064 & 0.016 & $\begin{array}{c}0.048 \\
(0.034)\end{array}$ \\
\hline Geithner Connections (Personal) & 0.046 & 0.006 & $\begin{array}{c}0.039 \\
(0.033)\end{array}$ & 0.054 & -0.002 & $\begin{array}{c}0.057 \\
(0.032)\end{array}$ & 0.054 & 0.015 & $\begin{array}{c}0.039 \\
(0.034)\end{array}$ \\
\hline Geithner Connections (New York) & 0.010 & -0.015 & $\begin{array}{c}0.025 \\
(0.022)\end{array}$ & 0.010 & -0.008 & $\begin{array}{c}0.018 \\
(0.027)\end{array}$ & 0.015 & -0.014 & $\begin{array}{c}0.029 \\
(0.027)\end{array}$ \\
\hline
\end{tabular}

Panel B: Propensity-score matched, CAR [0,10]

\begin{tabular}{|c|c|c|c|c|c|c|c|c|c|}
\hline & \multicolumn{3}{|c|}{ Match on Firm Size } & \multicolumn{3}{|c|}{ Match on Primary Control Variables } & \multicolumn{3}{|c|}{ Primary Controls and Others } \\
\hline & Conn. & Non-Conn. & Difference & Conn. & Non-Conn. & Difference & Conn. & Non-Conn. & Difference \\
\hline Geithner Connections (Schedule) & 0.161 & 0.021 & $\begin{array}{l}0.140 \text { ** } \\
(0.066)\end{array}$ & 0.127 & -0.013 & $\begin{array}{l}0.140 \text { *** } \\
(0.052)\end{array}$ & 0.131 & 0.087 & $\begin{array}{r}0.045 \\
(0.069)\end{array}$ \\
\hline Geithner Connections (Personal) & 0.157 & 0.009 & $\begin{array}{l}0.149 * \\
(0.078)\end{array}$ & 0.115 & 0.022 & $\begin{array}{r}0.093 \\
(0.068)\end{array}$ & 0.115 & 0.021 & $\begin{array}{r}0.094 \\
(0.068)\end{array}$ \\
\hline Geithner Connections (New York) & 0.136 & 0.098 & $\begin{array}{r}0.038 \\
(0.059) \\
\end{array}$ & 0.139 & 0.026 & $\begin{array}{l}0.112 \text { ** } \\
(0.054)\end{array}$ & 0.140 & 0.052 & $\begin{array}{r}0.088 * \\
(0.053)\end{array}$ \\
\hline
\end{tabular}

Panel C: Nonparametric matching estimator

\begin{tabular}{|c|c|c|c|c|c|c|c|c|c|}
\hline \multirow{3}{*}{$\begin{array}{l}\text { Geithner Connections } \\
\end{array}$} & \multicolumn{3}{|c|}{$\begin{array}{c}\text { Dependent variable is CAR [0] } \\
\text { (Full sample) }\end{array}$} & \multicolumn{3}{|c|}{$\begin{array}{c}\text { Dependent variable is CAR [0,1] } \\
\text { (Base sample) }\end{array}$} & \multicolumn{3}{|c|}{$\begin{array}{c}\text { Dependent variable is CAR [0,10] } \\
\text { (Base sample) }\end{array}$} \\
\hline & Schedule & Personal & New York & Schedule & Personal & New York & Schedule & Personal & New York \\
\hline & $\begin{array}{l}0.0047^{* * *} \\
(0.0014)\end{array}$ & $\begin{array}{l}0.0238^{* * *} \\
(0.0028)\end{array}$ & $\begin{array}{l}0.0413^{* * *} \\
(0.0098)\end{array}$ & $\begin{array}{l}0.0222^{* * *} \\
(0.005)\end{array}$ & $\begin{array}{l}0.054^{* * *} \\
(0.009)\end{array}$ & $\begin{array}{l}0.0666^{* *} \\
(0.026)\end{array}$ & $\begin{array}{l}0.050^{* * *} \\
(0.010)\end{array}$ & $\begin{array}{l}0.0988^{* * *} \\
(0.021)\end{array}$ & $\begin{array}{l}0.2922^{* * *} \\
(0.058)\end{array}$ \\
\hline
\end{tabular}


The table presents the weights used for the control group (non-connected) firms in the synthetic matching estimates. The weights presented are for the full sample where the treatment group is defined as firms connected according to the schedule measure of connections, as in Panel A of Table 5. Weights less than 0.005 are not reported in the table. Treatment Group (Connected Firms)

Control Group (Synthetic Matches)

\begin{tabular}{|c|c|c|c|c|c|c|c|c|}
\hline 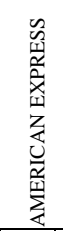 & 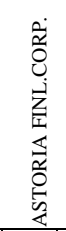 & 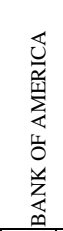 & 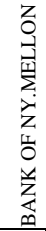 & 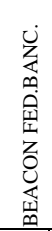 & 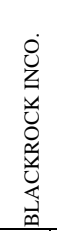 & 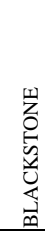 & $\begin{array}{l}\dot{8} \\
0 \\
z \\
0 \\
0 \\
0 \\
0 \\
0 \\
0\end{array}$ & 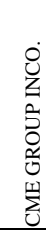 \\
\hline
\end{tabular}

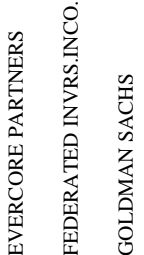

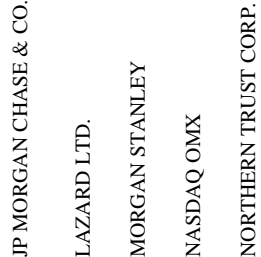

1ST.CMWL.FINL.CORP.

1ST.NIAG.FINL.GP.INCO.

0.05

\begin{tabular}{|l|c|}
\hline ADV.AM.CSH.ADV.CNTRS. & \\
\hline AFFILIATED MGRS.GP.INC & 0.09 \\
\hline
\end{tabular}

ALLBERN.HLDG.LP.

\begin{tabular}{ll}
0.09 \\
\hline & 0.07 \\
\hline
\end{tabular}

\begin{tabular}{ll|l|l|l|}
\hline & & & \\
\hline & &
\end{tabular}
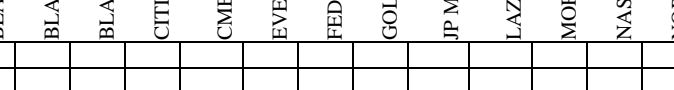

\begin{tabular}{|l|}
\hline AMERIPRISE FINL.INCO. \\
\hline ASSOCIATED BANC-COR \\
\hline
\end{tabular}

\begin{tabular}{l} 
ASSOCIATED BAN \\
\hline BANK MUT.CORP. \\
\hline
\end{tabular}

BANK OF HAWAII CORP.

BB\&T CORP.

BROOKLINE BANCORP INCO.

CAPITAL ONE FINL.CORP.

CAPITOL BANC.LTD.

CAPITOL FED.FINL.

CASCADE FINL.CORP.

CHARLES SCHWAB CORP.

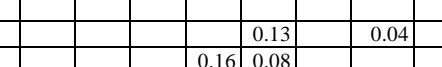
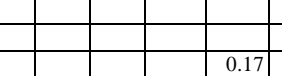

CHICOPEE BANCORP INCO.

CITY BANK

CITY NATIONAL CORP.

CMTY.BK.SHS.OF INDNA.

COMERICA INCO.

COOP.BANKSHARES INCO.

CULLEN FO.BANKERS INCO.

CVB FINANCIAL CORP

DOLLAR FINANCIAL CORP.

EATON VANCE CORP.

\begin{tabular}{|l|}
\hline EQUIFAX INCO. \\
\hline FIFTH THIRD BANCORP \\
\hline
\end{tabular}

FIRST FINL.HDG.INCO.

\begin{tabular}{l}
\hline FIRST HORIZON NAT.CORP. \\
\hline
\end{tabular}

FIRSTMERIT CORP.

FLUSHING FINL.CORP.

FPB BANCORP INCO

FRANKLIN RESOURCES INCO.

FULTON FINANCIAL CORP.

HARLEYSVILLE NAT.CORP.

HUDSON CITY BANC.INCO.

ICTL.EX.INCO,

INDEPENDENT BK.CORP.

INVESTORS BANCORP INCO.

JANUS CAPITAL GP.INCO.

\begin{tabular}{|l|l|l|l|l|}
\hline 0.07 & & & \\
\hline & & 0.01 \\
\hline
\end{tabular}

\begin{tabular}{ll|l|l|l|l|l|l|l}
\hline & 0.16 & 0.08 & & & & & \\
\hline & & & 0.01 & & & 0.15 & 0.0 \\
\hline
\end{tabular}

\begin{tabular}{l|l|l|l|}
\hline 0.17 & & 0.08 \\
\hline
\end{tabular}

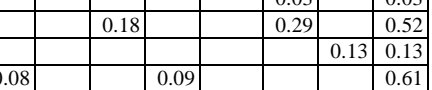

JEFFERIES GP.INCO.

KEYCORP

LEGG MASON INCO.

M\&T BK CORP.

MARKETAXESS HDG.INCO

MARSHALL \& ILSLEY CORP.

MB FINL.INCO.

NAT.PENN BCSH.INCO.

NBT BANCORP INCO.

NEWALLIANCE BCSH.INCO.

OPTIONSXPRESS HDG.INCO.

PEOPLES UTD.FINL.INCO.

PIPER JAFFRAY COS.

PNCL FINL PTNS INCO.

PROSPERITY BCSH.INCO,

RAYMOND JAMES FINL.INCO,

REGIONS FINL.CORP.

SEI INVS.CO.

STIFEL FINL.CORP.

\begin{tabular}{l} 
SUN BANCORP INCO. \\
\hline
\end{tabular}

SWS GP.INCO.

T ROWE PRICE GP.INCO.

\begin{tabular}{l} 
T ROWE PRICE GP.INCO. \\
\hline TD AMERITRADE HLDG.CORP.
\end{tabular}

\begin{tabular}{l|l|l|l|l|l|l}
0.07 & & & & & \\
\hline
\end{tabular}

\begin{tabular}{lll|l|l} 
& & & \\
\hline & & & \\
& & & \\
& & & \\
\hline 0.16 & & \\
\end{tabular}

\begin{tabular}{|l|l|l|l|l|l|l|l|l|l|l}
\hline & 0.23 & & & & & & & & 0.48 \\
\hline
\end{tabular}

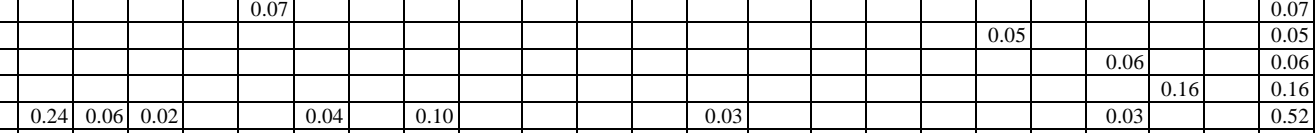

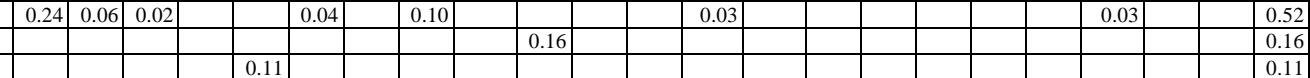

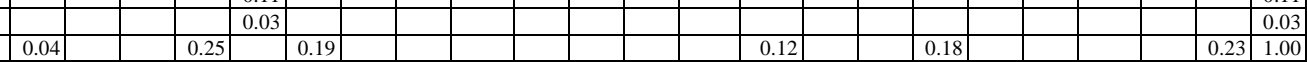
\begin{tabular}{ll|l|l|l|l|l|l|l|l}
\hline & & & & 0.44 & & \\
\hline
\end{tabular}

\begin{tabular}{ll|l|l|l|l|l|l|l|l|l|l|l|l|l} 
& & & & & 0.11 & 0.11 & & & & 0.05 & \\
\hline
\end{tabular} \begin{tabular}{|l|l|l|l|l|l|l|l|l|l|l|l|}
\hline & & & & & & & & & & 0.05 \\
\hline
\end{tabular}

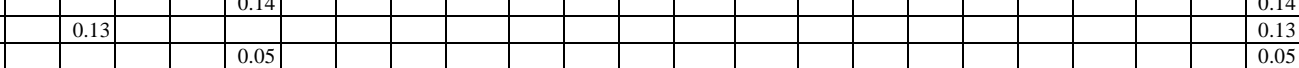

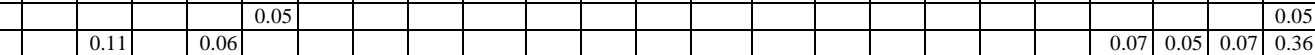

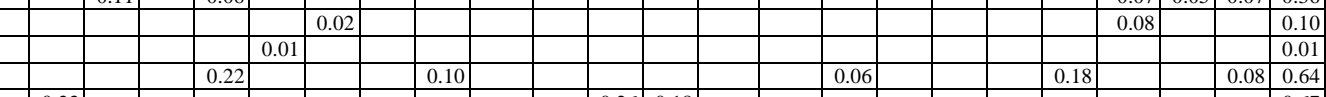

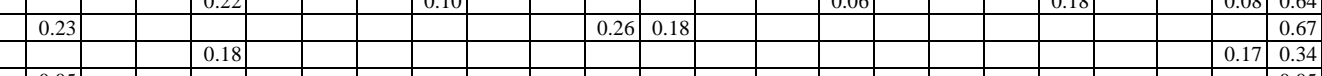
0.05

\begin{tabular}{lll|l|l|l}
\hline & & & & \\
\hline & & & & \\
\hline & & & & \\
\hline
\end{tabular}

\begin{tabular}{llllll} 
& & & & & \\
\hline & & & & & 0.06 \\
& 0.09 & 0.10 & 0.08 & & \\
\hline
\end{tabular}

\begin{tabular}{|llllllllllll|l|l|l|l|l}
\hline & & & & & & & & & & & 0.02 & 0.02 \\
\hline
\end{tabular}

\begin{tabular}{ll|l|l|l|l|l|l|l|l|l|l|l|l|l|}
\hline 0.09 & 0.10 & & & & & & & & & & & & & \\
\hline
\end{tabular}

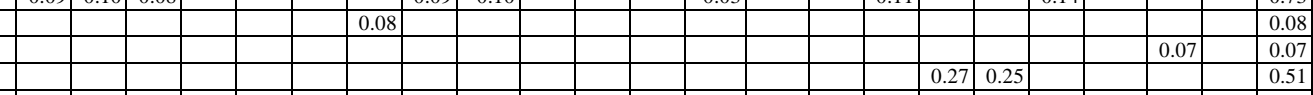

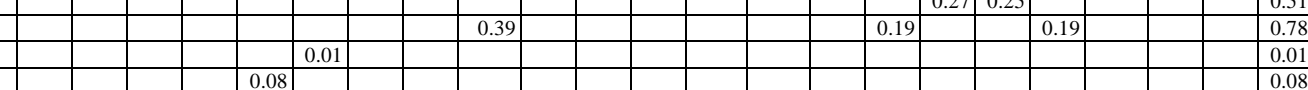

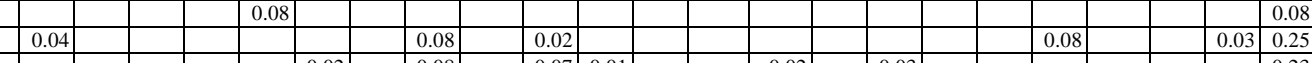
TRADESTATION GP.INCO.

TRICO BCSH

TRUSTCO BK.CORP.NY

TRUSTMARK CORP.

US BANCORP

UTD.BKSH.INCO.

WADDELL \& REFD FINL.INC

WEBSTER FINL.CORP.

\begin{tabular}{l} 
WEBSTER FINL.CORP \\
\hline WELLS FARGO \& CO \\
\hline WEST COAST BANCORP \\
\hline
\end{tabular}

WEST COAST BANCORP

WHITNEY HOLDING CORP.

WILMINGTON TST.CORP.

WINTRUST FINANCIAL CORP.

WORLD ACCEPTANCE CORP.

ZIONS BANCORPORATION

Sum of smaller weights not listed

Total weights

\begin{tabular}{l|l|l|l|l|l|l}
\hline & & & & \\
\hline & & 0.08 & \\
\hline
\end{tabular}

\begin{tabular}{|l|l|l|l|l|l|l|l}
0.02 & & 0.08 & & 0.07 & 0.01 \\
\hline
\end{tabular}

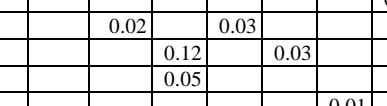

\begin{tabular}{|l|l|l|l|l|}
\hline & & & & 0.23 \\
\hline
\end{tabular}

\begin{tabular}{|lll|l|l|l|l|l|l|l|l|l|l|l|l|l|l|l|l|l|l|l|}
\hline & \\
\hline
\end{tabular}

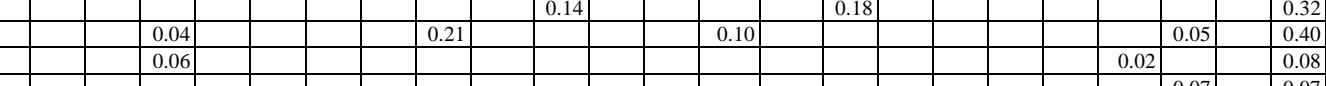

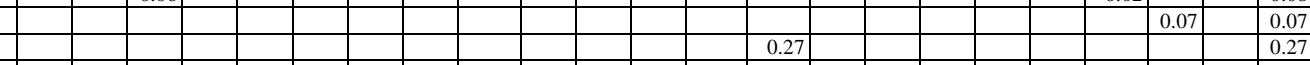

\begin{tabular}{|l|l|l|l|l|l|l|l|l|l|l|l|l|l|l|l|l|l|l|l|} 
& & & & & 0.04 & 0.04 \\
\hline
\end{tabular}

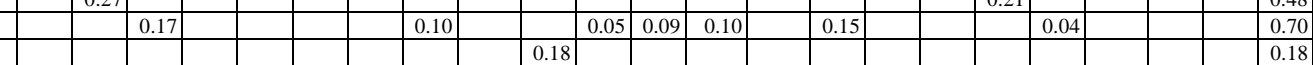

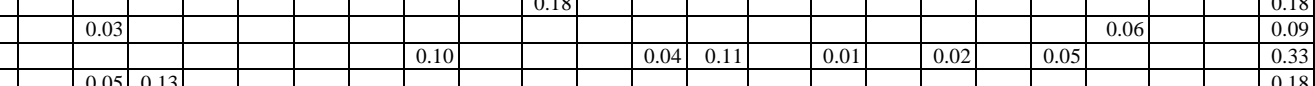

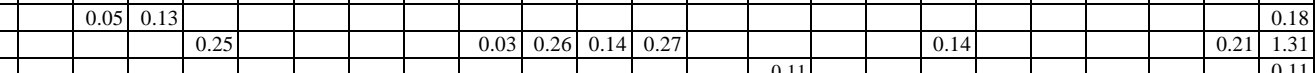
\begin{tabular}{ll}
\hline & \\
\hline
\end{tabular}

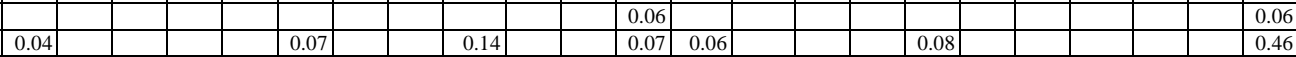
\begin{tabular}{|l|l|l|l|l|l|l|l|l|l|l|l|l|l|l|l|l}
0.07 & & 0.14 & & & 0.07 & 0.06 & & & & 0.08 & & & & & & 0.46 \\
\hline 0.08 & 0.02 & & & & & 0.09 & & & & 0.07 & & & & & & \\
\hline
\end{tabular} \begin{tabular}{ll|l|}
\hline 0.27 & 0.21 \\
\hline
\end{tabular}

0.12

\begin{tabular}{ll|l|l|l|l|l|}
\hline+ & & & 0.08 & 0.02 \\
\hline
\end{tabular}
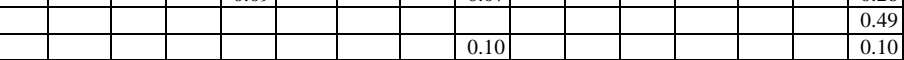

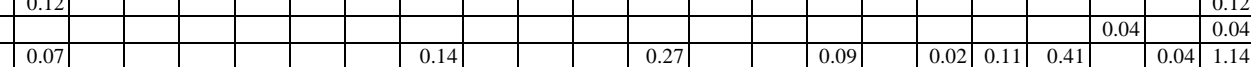

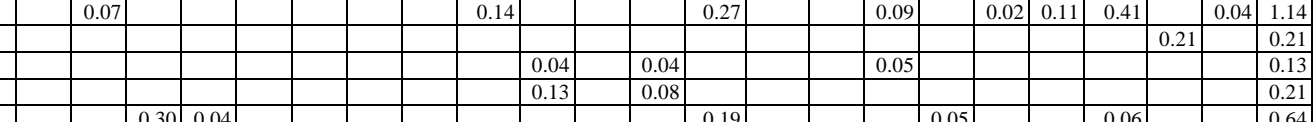

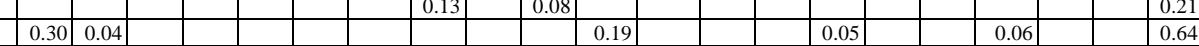

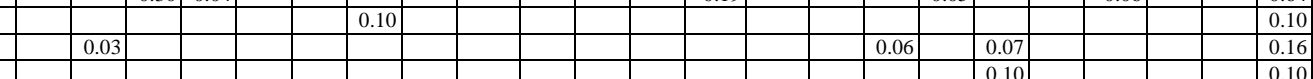

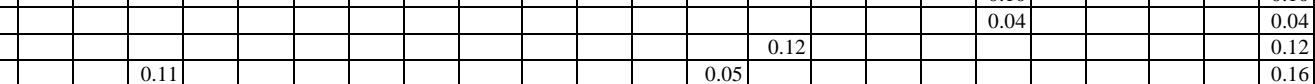

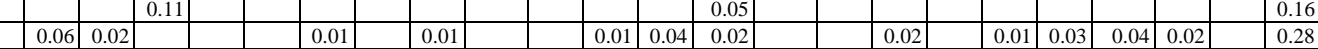
\begin{tabular}{|l|l|l|l|l|l|l|l|l|l|l|l|l|l|l|l|l|l|l|l|l|l|l|l|l|l|l}
\hline & 1.00 & 1.00 & 1.00 & 1.00 & 1.00 & 1.00 & 1.00 & 1.00 & 1.00 & 1.00 & 1.00 & 1.00 & 1.00 & 1.00 & 1.00 & 1.00 & 1.00 & 1.00 & 1.00 & 1.00 & 1.00 & 1.00 & \\
\hline
\end{tabular} 
Appendix Table A8

Personal Connections of Other Treasury Secretary Candidates to Financial Firms

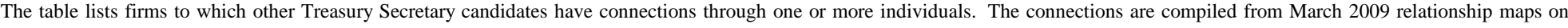

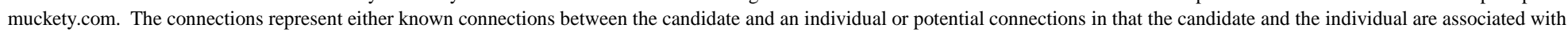
the same organization.

\begin{tabular}{|c|c|c|c|c|c|}
\hline Firm & Connected Person & Position with Firm & Connection to Candidate & $\begin{array}{c}\text { Candidates' Position with } \\
\text { Connection } \\
\end{array}$ & $\begin{array}{c}\text { Connected Person's } \\
\text { Position with Connection }\end{array}$ \\
\hline \multicolumn{6}{|c|}{ Panel A: Lawrence Summers } \\
\hline BlackRock & Laurence D. Fink & chairman \& CEO & Informal Adviser & NA & NA \\
\hline Blackstone Group & Richard E. Salomon & adv. board chair, alt. asset mgt. & Peterson Institute for International Economics & director & director \\
\hline Blackstone Group & Peter G. Peterson & chairman and co-founder & Peterson Institute for International Economics & director & chairman \\
\hline Charles Schwab & Donald G. Fisher & director & Teach for America & director & director \\
\hline Charles Schwab & Paula A. Sneed & director & Teach for America & director & director \\
\hline Citigroup & Robert E. Rubin & director & Summers is Protégé of Rubin & NA & NA \\
\hline Citigroup & Richard D. Parsons & chairman & Obama-Biden economic advisory team & member & member \\
\hline Citigroup & Judith Rodin & director & Brookings Institution & trustee & honorary trustee \\
\hline Citigroup & Anne M. Mulcahy & director & Obama-Biden economic advisory team & member & member \\
\hline Goldman Sachs & James A. Johnson & director & Brookings Institution & trustee & honorary trustee \\
\hline Goldman Sachs & John C. Whitehead & foundation chairman & Brookings Institution & trustee & honorary trustee \\
\hline Goldman Sachs & Richard A. Friedman & managing director & Mount Sinai Medical Center (New York) & trustee & trustee \\
\hline Goldman Sachs & Suzanne Nora Johnson & senior director & Brookings Institution & trustee & trustee \\
\hline Goldman Sachs & Abby Joseph Cohen & senior investment strategist & Brookings Institution & trustee & trustee \\
\hline Icahn Enterprises & Carl C. Icahn & owner & Mount Sinai Medical Center (New York) & trustee & trustee \\
\hline JP Morgan Chase & George P. Shultz & chairman international council & American Corporate Partners & adv. council member & adv. council member \\
\hline JP Morgan Chase & William M. Daley & chairman Midwest division & Obama-Biden economic advisory team & member & member \\
\hline JP Morgan Chase & Ernesto Zedillo & int'l advisory board member & Peterson Institute for International Economics & director & director \\
\hline Lazard & Vernon E. Jordan Jr. & director & Brookings Institution & trustee & honorary trustee \\
\hline Morgan Stanley & Laura D'Andrea Tyson & director & Brookings Institution & trustee & trustee \\
\hline Morgan Stanley & Laura D'Andrea Tyson & director & Obama-Biden economic advisory team & member & member \\
\hline Morgan Stanley & Hutham S. Olayan & director & Peterson Institute for International Economics & director & director \\
\hline Morgan Stanley & Laura D'Andrea Tyson & director & Peterson Institute for International Economics & director & director \\
\hline NASDAQ & Glenn H. Hutchins & director & Brookings Institution & trustee & trustee \\
\hline NYSE & Shirley Ann Jackson & director & Brookings Institution & trustee & trustee \\
\hline Och-Ziff & David Windreich & partner & Mount Sinai Medical Center (New York) & trustee & trustee \\
\hline Sallie Mae & Barry A. Munitz & director & Broad Foundations & governor & governor \\
\hline VISA & Suzanne Nora Johnson & director & Brookings Institution & trustee & trustee \\
\hline \multicolumn{6}{|c|}{ Panel B: Paul Volcker } \\
\hline Blackstone Group & Peter G. Peterson & chairman \& co-founder & Concord Coalition & director & founding president \\
\hline Blackstone Group & Peter G. Peterson & chairman \& co-founder & Japan Society & life director & life director \\
\hline Blackstone Group & Peter G. Peterson & chairman \& co-founder & Peterson Institute for International Economics & director & chairman \\
\hline Blackstone Group & Richard E. Salomon & adv. board chair, alt. asset mgt. & Peterson Institute for International Economics & director & director \\
\hline Capital One & Patrick W. Gross & director & Aspen Institute & lifetime trustee & trustee \\
\hline CIT Group & James S. McDonald & director & Japan Society & life director & director \\
\hline Citigroup & Richard D. Parsons & chairman & Obama-Biden economic advisory team & member & member \\
\hline Citigroup & Robert E. Rubin & director & Concord Coalition & director & director \\
\hline Citigroup & Anne M. Mulcahy & director & Obama-Biden economic advisory team & member & member \\
\hline Goldman Sachs & Stephen Friedman & director & Aspen Institute & lifetime trustee & trustee \\
\hline Goldman Sachs & John C. Whitehead & foundation chairman & Financial Services Volunteer Corps & honorary chairman & co-founder \& chairman \\
\hline Goldman Sachs & John C. Whitehead & foundation chairman & International House & chairman & honorary trustee \\
\hline Goldman Sachs & Josef Joffe & foundation member & Aspen Institute & lifetime trustee & member \\
\hline Goldman Sachs & E. Gerald Corrigan & managing director & Group of Thirty & chairman of the board & member \\
\hline Goldman Sachs & Henry Cornell & managing director & Japan Society & life director & director \\
\hline JPMorgan Chase & William M. Daley & chairman Midwest division & Obama-Biden economic advisory team & member & member \\
\hline JPMorgan Chase & William H. Gray III & director & Concord Coalition & director & director \\
\hline JPMorgan Chase & Andrew D. Crockett & executive committee member & Group of Thirty & chairman of the board & member \\
\hline JPMorgan Chase & Ernesto Zedillo & int'l advisory board member & Peterson Institute for International Economics & director & director \\
\hline Moody's & Henry A. McKinnell Jr. & director & Japan Society & life director & life director \\
\hline Morgan Stanley & Laura D'Andrea Tyson & director & Obama-Biden economic advisory team & member & member \\
\hline Morgan Stanley & Hutham S. Olayan & director & Peterson Institute for International Economics & director & director \\
\hline Morgan Stanley & Laura D'Andrea Tyson & director & Peterson Institute for International Economics & director & director \\
\hline Morgan Stanley & Frederick B. Whittemore & partner/managing director & Aspen Institute & lifetime trustee & trustee \\
\hline NASDAQ & Merit E. Janow & director & Japan Society & life director & director \\
\hline NYSE & James S. McDonald & director & Japan Society & life director & director \\
\hline \multicolumn{6}{|l|}{ Panel C: Sheila Bair } \\
\hline NYSE & Self & senior vice president (former) & NA & NA & NA \\
\hline \multicolumn{6}{|c|}{ Panel D: Jon Corzine } \\
\hline Bank of New York & Gerald L. Hassell & president & New York Philharmonic & director emeritus & director \\
\hline Fannie Mae & Philip A. Laskawy & chairman & New York Philharmonic & director emeritus & director \\
\hline Goldman Sachs & Self & chairman \& CEO (former) & NA & NA & NA \\
\hline Goldman Sachs & John F. W. Rogers & partner \& foundation trustee & Corzine's former chief of staff & NA & NA \\
\hline Lazard & Philip A. Laskawy & director & New York Philharmonic & director emeritus & director \\
\hline US Bancorp & Jerry W. Levin & director & New York Philharmonic & director emeritus & director \\
\hline
\end{tabular}


Appendix Table A9

Connections to Geithner and Stock Price Reactions to Tax Problems

The table presents stock returns of financial firms around the announcement of Geithner's tax errors and delayed confirmation hearing. Event day 0 is January 14, 2009; the tax problems were disclosed by the Senate Finance Committee on January 13, 2009 after market closing. Abnormal returns are calculated using the market model with an estimation window of 250 trading days ending 30 days prior to event day 0 . The base sample excludes firms with returns highly correlated to Citigroup or Bank of America. Schedule connections denote the number of meetings between the firm's executives and Geithner during 2007-08; personal connections denote the number of shared board memberships between the firm's executives and Geithner; New York connections indicate firms headquartered in New York City. Asterisks denote significance levels of a two-tailed t-test (***=1\%, **=5\%, *=10\%).

\section{Panel A: Actual returns, Base sample}

\begin{tabular}{|c|c|c|c|c|c|c|c|c|c|c|}
\hline \multirow[b]{2}{*}{ Event Day } & \multirow[b]{2}{*}{ Date } & \multicolumn{3}{|c|}{ Schedule Connections } & \multicolumn{3}{|c|}{ Personal Connections } & \multicolumn{3}{|c|}{ New York Connections } \\
\hline & & Conn. & Non-Conn. & Difference & Conn. & Non-Conn. & Difference & Conn. & Non-Conn. & Difference \\
\hline 0 & $1 / 14 / 2009$ & -0.054 & -0.029 & -0.025 & -0.053 & -0.029 & -0.024 & -0.054 & -0.028 & $-0.027 * *$ \\
\hline 1 & $1 / 15 / 2009$ & -0.008 & 0.000 & -0.009 & -0.024 & 0.001 & -0.025 & 0.020 & -0.001 & $0.021 * *$ \\
\hline 2 & $1 / 16 / 2009$ & 0.005 & -0.002 & 0.007 & -0.011 & -0.002 & -0.009 & -0.002 & -0.002 & 0.000 \\
\hline 3 & 1/19/2009 & -0.119 & -0.061 & $-0.058 * *$ & -0.070 & -0.062 & -0.009 & -0.076 & -0.061 & -0.015 \\
\hline $0-3$ & (Cumulative) & -0.169 & -0.090 & $-0.079 * *$ & -0.145 & -0.091 & -0.054 & -0.110 & -0.090 & -0.020 \\
\hline 4 & $1 / 20 / 2009$ & 0.071 & 0.039 & 0.032 & 0.101 & 0.038 & $0.062 * *$ & 0.085 & 0.036 & $0.049 * * *$ \\
\hline
\end{tabular}

Panel B: Cumulative abnormal returns, Base sample

\begin{tabular}{|c|c|c|c|c|c|c|c|c|c|c|}
\hline \multirow[b]{2}{*}{ Event Day } & \multirow[b]{2}{*}{ Date } & \multicolumn{3}{|c|}{ Schedule Connections } & \multicolumn{3}{|c|}{ Personal Connections } & \multicolumn{3}{|c|}{ New York Connections } \\
\hline & & Conn. & Non-Conn. & Difference & Conn. & Non-Conn. & Difference & Conn. & Non-Conn. & Difference \\
\hline 0 & $1 / 14 / 2009$ & -0.014 & -0.006 & -0.008 & -0.008 & -0.006 & -0.002 & -0.018 & -0.006 & -0.012 \\
\hline 1 & $1 / 15 / 2009$ & -0.024 & -0.007 & -0.018 & -0.034 & -0.007 & -0.028 & 0.000 & -0.008 & 0.008 \\
\hline 2 & $1 / 16 / 2009$ & -0.029 & -0.014 & -0.015 & -0.056 & -0.014 & -0.042 & -0.010 & -0.015 & 0.005 \\
\hline 3 & 1/19/2009 & -0.085 & -0.039 & -0.046 & -0.056 & -0.040 & -0.016 & -0.028 & -0.041 & 0.013 \\
\hline 4 & $1 / 20 / 2009$ & -0.066 & -0.030 & -0.037 & -0.014 & -0.031 & 0.017 & 0.009 & -0.034 & $0.043 * *$ \\
\hline
\end{tabular}

Panel C: Actual returns, Full sample

\begin{tabular}{|c|c|c|c|c|c|c|c|c|c|c|}
\hline \multirow[b]{2}{*}{ Event Day } & \multirow[b]{2}{*}{ Date } & \multicolumn{3}{|c|}{ Schedule Connections } & \multicolumn{3}{|c|}{ Personal Connections } & \multicolumn{3}{|c|}{ New York Connections } \\
\hline & & Conn. & Non-Conn. & Difference & Conn. & Non-Conn. & Difference & Conn. & Non-Conn. & Difference \\
\hline 0 & $1 / 14 / 2009$ & -0.058 & -0.032 & $-0.026 * *$ & -0.063 & -0.032 & $-0.031 * *$ & -0.059 & -0.031 & $-0.028 * * *$ \\
\hline 1 & $1 / 15 / 2009$ & -0.026 & -0.003 & $-0.023 *$ & -0.051 & -0.003 & $-0.048 * * *$ & 0.007 & -0.005 & 0.012 \\
\hline 2 & $1 / 16 / 2009$ & -0.011 & -0.003 & -0.009 & -0.031 & -0.002 & $-0.029 * *$ & -0.006 & -0.003 & -0.003 \\
\hline 3 & $1 / 19 / 2009$ & -0.145 & -0.066 & $-0.078 * * *$ & -0.132 & -0.067 & $-0.065 * * *$ & -0.091 & -0.068 & $-0.023 *$ \\
\hline $0-3$ & (Cumulative) & -0.217 & -0.101 & $-0.116 * * *$ & -0.243 & -0.101 & $-0.142 * * *$ & -0.140 & -0.103 & $-0.037 *$ \\
\hline 4 & $1 / 20 / 2009$ & 0.130 & 0.043 & $0.087 * * *$ & 0.148 & 0.043 & $0.105 * * *$ & 0.104 & 0.042 & $0.063 * * *$ \\
\hline \multicolumn{11}{|c|}{ Panel D: Cumulative abnormal returns, Full sample } \\
\hline & & \multicolumn{3}{|c|}{ Schedule Connections } & \multicolumn{3}{|c|}{ Personal Connections } & \multicolumn{3}{|c|}{ New York Connections } \\
\hline Event Day & Date & Conn. & Non-Conn. & Difference & Conn. & Non-Conn. & Difference & Conn. & Non-Conn. & Difference \\
\hline 0 & $1 / 14 / 2009$ & -0.013 & -0.007 & -0.006 & -0.015 & -0.007 & -0.008 & -0.018 & -0.006 & -0.012 \\
\hline 1 & $1 / 15 / 2009$ & -0.041 & -0.011 & $-0.030 *$ & -0.068 & -0.010 & $-0.058 * * *$ & -0.013 & -0.012 & -0.001 \\
\hline 2 & $1 / 16 / 2009$ & -0.064 & -0.020 & $-0.044 * *$ & -0.111 & -0.018 & $-0.093 * * *$ & -0.028 & -0.021 & -0.007 \\
\hline 3 & $1 / 19 / 2009$ & -0.137 & -0.047 & $-0.091 * * *$ & -0.166 & -0.046 & $-0.120 * * *$ & -0.055 & -0.050 & -0.005 \\
\hline 4 & $1 / 20 / 2009$ & -0.067 & -0.037 & -0.031 & -0.083 & -0.036 & $-0.047 *$ & -0.004 & -0.041 & $0.037 * *$ \\
\hline
\end{tabular}


Appendix Table A10

Connections to Geithner and Reactions to Tax Problems, OLS and Synthetic Matching Estimates

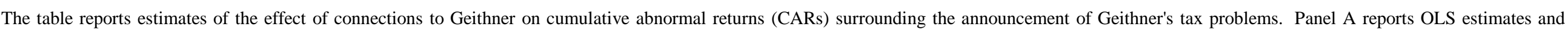

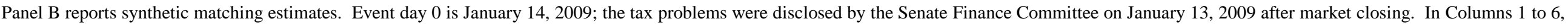

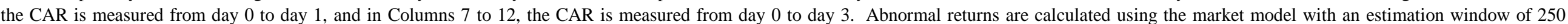

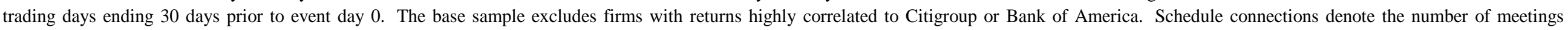

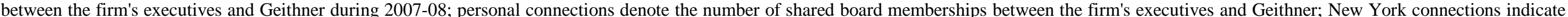

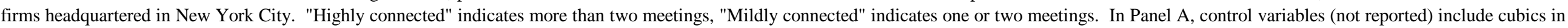

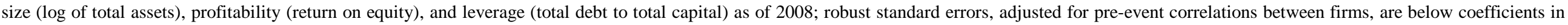

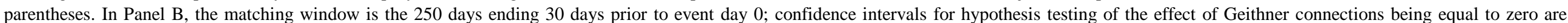
computed according to 5,000 placebo simulations. Asterisks denote significance levels ( $* * *=1 \%, * *=5 \%, *=10 \%)$.

\begin{tabular}{|c|c|c|c|c|c|c|c|c|c|c|c|c|}
\hline & $(1)$ & $(2)$ & (3) & $(4)$ & $(5)$ & $(6)$ & $(7)$ & $(8)$ & $(9)$ & $(10)$ & $(11)$ & $(12)$ \\
\hline \multicolumn{13}{|l|}{ Panel A: OLS estimates } \\
\hline & \multicolumn{6}{|c|}{ Dependent variable is CAR $[0,1]$} & \multicolumn{6}{|c|}{ Dependent variable is CAR $[0,3]$} \\
\hline \multirow[b]{3}{*}{ Geithner Connections } & \multicolumn{3}{|c|}{ Base sample } & \multicolumn{3}{|c|}{ Full sample } & \multicolumn{3}{|c|}{ Base sample } & \multicolumn{3}{|c|}{ Full sample } \\
\hline & Schedule & Personal & New York & Schedule & Personal & New York & Schedule & Personal & New York & Schedule & Personal & New York \\
\hline & $\begin{array}{l}-0.002 \\
(0.003)\end{array}$ & $\begin{array}{l}-0.010 \\
(0.010)\end{array}$ & $\begin{array}{c}0.014 \\
(0.011)\end{array}$ & $\begin{array}{l}-0.0033^{* * *} \\
(0.001)\end{array}$ & $\begin{array}{l}-0.005 \\
(0.004)\end{array}$ & $\begin{array}{c}0.016 \\
(0.010)\end{array}$ & $\begin{array}{c}0.001 \\
(0.005)\end{array}$ & $\begin{array}{c}0.004 \\
(0.014)\end{array}$ & $\begin{array}{c}0.026 * \\
(0.015)\end{array}$ & $\begin{array}{l}-0.001 \\
(0.002)\end{array}$ & $\begin{array}{c}0.005 \\
(0.006)\end{array}$ & $\begin{array}{c}0.032 \text { ** } \\
(0.014)\end{array}$ \\
\hline Number of firms & 515 & 515 & 515 & 583 & 583 & 583 & 515 & 515 & 515 & 583 & 583 & 583 \\
\hline R-squared & 0.058 & 0.058 & 0.059 & 0.116 & 0.113 & 0.115 & 0.113 & 0.113 & 0.116 & 0.209 & 0.209 & 0.213 \\
\hline \multicolumn{13}{|c|}{ Panel B: Synthetic matching estimates } \\
\hline & \multicolumn{6}{|c|}{ Dependent variable is CAR $[0,1]$} & \multicolumn{6}{|c|}{ Dependent variable is CAR $[0,3]$} \\
\hline & \multicolumn{3}{|c|}{ Base sample } & \multicolumn{3}{|c|}{ Full sample } & \multicolumn{3}{|c|}{ Base sample } & \multicolumn{3}{|c|}{ Full sample } \\
\hline & All Conn. & Highly Conn. & Mildly Conn. & All Conn. & Highly Conn. & Mildly Conn. & All Conn. & Highly Conn. & Mildly Conn. & All Conn. & Highly Conn. & Mildly Conn. \\
\hline Geithner Connections (Schedule) & -0.020 & -0.048 & -0.014 & -0.002 & $-0.031 *$ & 0.016 & $-0.051 * *$ & -0.081 & $-0.044 *$ & $-0.056 * * *$ & $-0.173 * * *$ & 0.012 \\
\hline Confidence interval (2.5\%) & -0.035 & -0.108 & -0.040 & -0.018 & -0.035 & -0.028 & -0.040 & -0.126 & -0.049 & -0.021 & -0.046 & -0.033 \\
\hline Confidence interval (97.5\%) & 0.042 & 0.094 & 0.050 & 0.032 & 0.046 & 0.040 & 0.072 & 0.142 & 0.078 & 0.055 & 0.080 & 0.066 \\
\hline Number of firms & 515 & 507 & 513 & 583 & 570 & 574 & 515 & 507 & 513 & 583 & 570 & 574 \\
\hline Number in treatment group & 10 & 2 & 8 & 22 & 9 & 13 & 10 & 2 & 8 & 22 & 9 & 13 \\
\hline
\end{tabular}

